

\section{Monolithic Amorphous Silicon Modules on Conthuous Polymer Substrate}

\section{Final Subcontract Report}

9 January 1991 - 1 April 1991

D.P. Grimmer

Iowa Thin Film Technologies

Ames, Iowa

NREL technical monitor: R. Mitchell

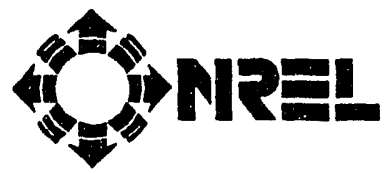

National Renewable Energy Laboratory

(formerly the Solar Energy Research Institute) 1617 Cole Boulevard Golden, Colorado 80401-3393

A Division of Midwest Research Institute Operated for the U.S. Department of Energy under Contract No. DE-AC02-83CH10093

Prepared under Subcontract No. XC-1-10057-18

March 1992

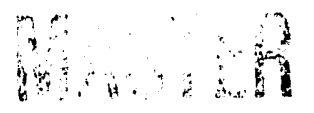


On September 16, 1991 the Solar Energy Institute was designated a national laboratory, and Its name was changed to the National Renewable Energy Laboratory.

\section{NOTICE}

This report was prepared as an account of work sponsored by an agency of the United States government. Neither the United States government nor any agency thereof, nor any of their employees, makes any warranty, express or implied, or assumes any legal liability or responsibility for the dccuracy, completeness, or usefulness of any information, apparatus, product, or process disclosed, or represents that its use would not infringe privately owned rights. Reference herein to any specific commercial product, process, or service by trade name, trademark, manufacturer, or otherwise does not necessarily constitute or imply its endorsement, recommendation, or favoring by the United States government or any agency thereof. The views and opinions of authors expressed herein do not necessarily state or reflect those of the United States government or any agency thereof.

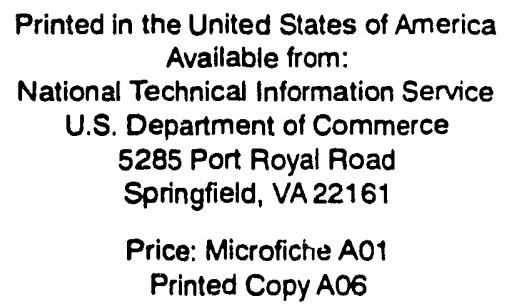

Codes are used for pricing all publications. The code is determined by the number of pages in the publication. Information pertaining to the pricing codes can be found in the current issue of the following publications which are generally available in most libraries: Energy Research Abstracts (ERA); Government Reports Announcements and Index (GRA and 1); Scientific and Technical Abstract Reports (STAR); and publication NTIS-PR-360 available from NTIS at the above address. 


\section{RECEIVED}

\section{APR 11991}

FINAL TECHNICAL REPORT

March 1991

Photovoltaic Manufacturing Technology--Phase I

"Monolithic Amorphous Silicon Modules on Continuous polymer Substrate"

Iowa Thin Film Technologies, Inc.

Suite 607 , ISIS

ISU Research Park

Ames, IA 50010

This report has been prepared under subcontract XC-1-10057-18 under prime contract DE-AC02-83CH10093 with SERI.

Table of Contents

1) Significant work performed during the subcontract period of performance -- p. 2 .

2) Task I - Overall procedure description -- p. 4

3) Task 2 - Potential process improvements -- p. 9

4) Task 3 - Identified problems description -- p. 19

5) Task 4 - Approaches to problem solution -- p. 22

6) Appendices -- p. 29 
Significant work performed during the subcontract period of performance.

A thorough search was conducted for vendors of necessary manufacturing equipment applicable to the proposed processes. Information was gathered about makers of web cutting, sheet holepunching, automatic sheet load and take off, web- and sheetwashing and drying systems, and similar types of equipment used for screen-printing and flexible circuit board processes in the semiconductor industry. The NEPCON-West '91 (National Electronic Packaging and Production Conference) Exposition was attended Feb. 25-28 in Anaheim, CA, at our company's expense, to gain firsthand knowledge of pertinent equipment and vendors. Information gathered on capital equipment costs and processing times has been used as inputs in the manufacturing simulation program, SIMAN IV (from Systems Modeling Corp., Sewickley, PA).

In addition to the vencor/equipment search, some experimental work was done to insure feasibility of certain steps in the improved-process. A preliminary screen-printable etchinggel was developed for patterning the zno top contact, to prove the concept. A corresponding extra-thick screen emulsion was developed to print the necessary gel thickness for etchpatterning. Experiments were also performed on laminating EVA and EAA as stiffener sheets to the backs of fully-coated web sheets. These stiffeners make handling sheets easier, and can be applied after all depositions are completed in the new process sequence. The polymer-backed sheets are then etch fabricated into functioning solar modules. To make modules with good performance, special conductor inks were developed with very low contact resistance. Stock inks from a number of vendors make unsatisfactory contact with zno, so an improved (but not optimized) ink was developed internally.

The manufacturing simulation program, SIMAN IV, was installed on our company's 386 PC to run continuing validation studies on the manufacturing processes used in the pilot-plant. As our manufacturing data base improves, the manufacturing simulation will be refined as an aid in the next generation of manufacturing facility.

We began developing simulation models of the manufacturing processes. These will allow us in the future to: (1) optimize production batch size; and (2) determine quality control policy as to where and when to do production-line testing. Economic models are used in tandem with the manufacturing simulation model, to obtain the lowest cost per module area or per watt. Hence, another use of these models is to decide where to allocate future capital resources in the production process.

The various manufacturing alternatives and improvements were evaluated using SIMAN IV and compared with the base-line pilotplant processes. These are discussed in detail in Appendix 3 . 
To summarize briefly, the baseline case of roll-to-roll processing without print-etching steps, yielded a manufacturing cost per one ft 2 module of $\$ 5.67$. The case of roli-to-roli deposition with sheet module processing using automatic feed and a print-etch step yielded a cost of $\$ 5.84$ per one $f t 2$ module. Finally, the case of roll-to-roll deposition with roll-to-roll module processing and a print-etch step yielded a cost of $\$ 5.66$ per one ft2 module. (Sheet module processing with hand-feed rather than altomatic feed stations, yielded higher costs, around $\$ 6.70$ per module). Since the various scenarios (except for handfeed sheet or piece stations) were within $\$ 0.20$ of each other for a one $f t 2$ module, research will continue with alternative methods until a clear winner is distinguished technically and economically. As operational data is gathered on the pilot-line, the model will be updated and used in this analysis. From an industrial engineering perspective, methods that do all deposition processes first will be favored, because the station scheduling will be easier. Because the a-si and zno depositions appear to be the bottleneck steps, adding one each additional asi and zno machines could double production output without increasing labor costs.

Assuming a 6 wp one ft 2 module, the case for the baseline, print-etch/sheet, and print-etch/roll-to-roll configurations are $\$ 0.95 / \mathrm{Wp}, \$ 0.97 / \mathrm{Wp}$, and $\$ 0.94 / \mathrm{Wp}$, respectively. 
SERI Manufacturing Initiative--Phase 1

Task 1.

Description of the overall procedure involved in manufacture of modules and/or cells. (specify any technology from other companies/sources upon which reliant).

Module fabrication processes developed involve fabrication steps before the top transparent conducting contact (TCC) is deposited. These methods are described in the paper "Fabrication of Photovoltaic Module Series Interconnects Between a-Si:H Thin Film Solar Cells Deposited on Flexible polyimide Substrates," D.P. Grimmer et al., Fourth International Photovoltaic Science and Engineering Conference (PVSEC-4), Sydney, Australia, 14-17 February 1989 (see Appendix 1).

The module fabrication processes require initial laser scribing through the $\mathrm{a}-\mathrm{Si}: \mathrm{H}$ and Al layers down to the bare polyimide and the screen printing of insulator inks over the open cuts in the deposited layers. This screen-printing step, as well as additional screen-printing and laser-scribing steps done after TCC deposition, require roll-to-roll registration on the initial scribe.

An itemized list of step-by-step module processes, procedures and the types of equipment used is described below and shown in Fig. 1:

\section{(1) Metalization system.}

The first step in the manufacturing process is metalization of the polymer web. The polyimide web material is initially baked at $400 \mathrm{C}$ prior to priming with stainless steel and depositing aluminum as the bottom electrode of the p-i-n device. The baking/outgasing, priming and metalization is done in a 5 ; diameter cylindrical deposition chamber capable of processing rolls of web material up to $15 "$ in width. Depositions are done by DC sputtering from 7 different targets. The additional targets allow for multiple metalization layers and diffusion barrier depositions. Hence, the system is designed to allow single-pass preparation of the substrate for the silicon deposition system. Typical thickness of the textured Al deposited is $4000 \mathrm{~A}$. The system is also designed to do double duty and deposit TCC and top protective films for certain environments. It will accomodate any of the sputter processes currently used for top contacts. A roll approximately 2400 ' long can be accommodated in all stages of the manufacturing process.

(2) Amorphous silicon deposition system.

The next step in the manufacturing process is deposition of a-si p-i-n device material. A single junction a-si device is deposited by plasma enhanced CVD (PECVD) or "glow discharge" of 
Fig. 1 Current, Baseline Roll-to-Roll A-Si Thin Film PV Module

Firoduction Process Steps

Step \# Production Step

(1) Metalization of

Polydimide web

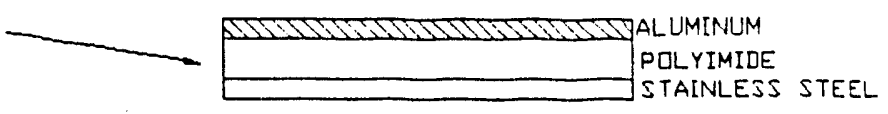

(2)

A-Si p-i-n deposition

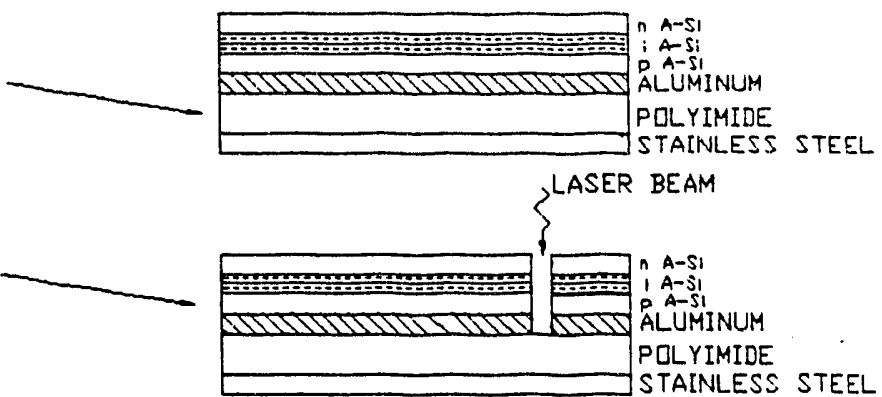

(4)

Screen-printing of insulator ink over scribe region

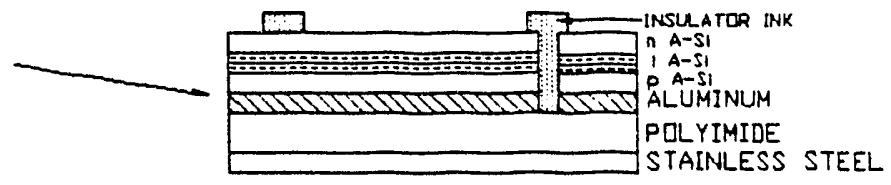

(5)

Znd top contact deposition

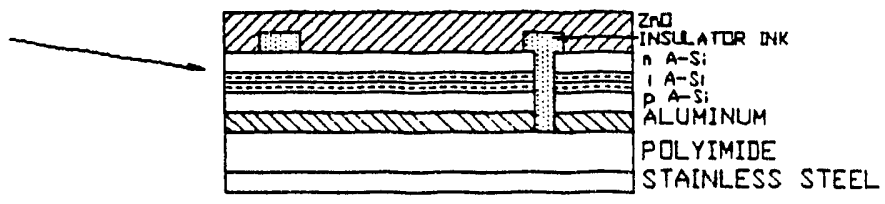

Laser scribing of open in Zno top contact

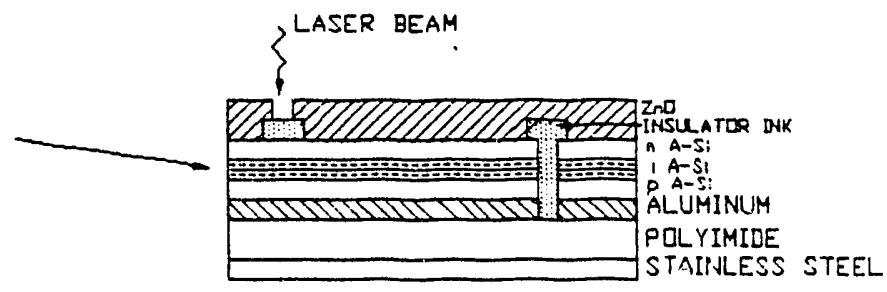

Screen-printing of Ag conducting ink

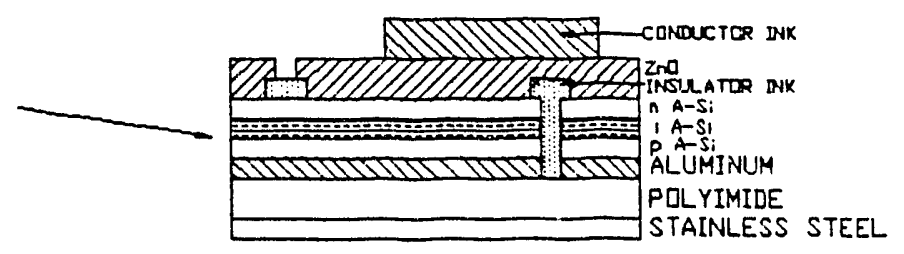

(8)

Laser welding of Ag ink/Zna

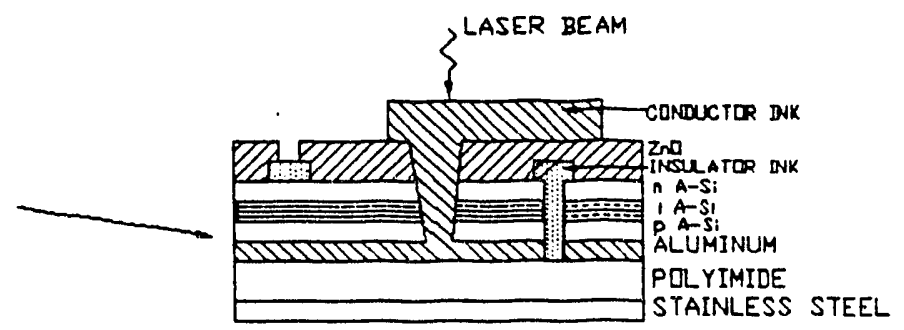

Busbar attachment 
SiH4 in a roll-to-roll multichamber system. The outer vacuum can is approximately $10^{\prime}$ ' long $x 3^{\prime}$ wide $x 4^{\prime}$ high, and is the vacuum plenum for separate, inner chambers to deposit phosphorous dopednt, intrinsic, and boron-doped pt layers. The multichamber design has been shown to have excellent dopant gas isolation between chambers. Typically, $n+, i$, and $p+$ layers have thicknesses of $150 \mathrm{~A}, 4000 \mathrm{~A}$, and $250 \mathrm{~A}$, respectively. A web speed of 6" per minute is planned. The amorphous silicon deposition is one of the throughput-limiting deposition processes: the metalization has significantly higher production rates, but the TCC deposition is comparable to a-si throughput. The capacity of the $13 "$ a-si multichamber is calculated to be $i$ MWp per year for single-junction devices.

\section{(3) Laser scribing of a-si/metal coating.}

Next, laser scribing is used to pattern the deposits of a$\mathrm{Si} / \mathrm{Al}$ into individual cells on the polyimide substrate. A YAG laser, operating at $1064 \mathrm{~nm}$, is used to scribe down to the bare insulating polyimide, thereby isolating the individual cells from one another. Initially, a single beam at $532 \mathrm{~nm}$ has been used to test the concept, and to have the convenience of a visible beam. However, the increased power available at $1064 \mathrm{~nm}$ and the need for multiple laser scribing beams, makes a switch to the YAG laser in the IR and the use of fiber optics for beam delivery an attractive alternative. The $1064 \mathrm{~nm}$ YAG laser with fiber-optic delivery will reduce capital costs and improve throughput. Due to its large size (5' long support rails and $20 " \times 30 "$ " scribing platen), the $13 "$ pilot plant scriber remains fixed except to rotate, and the fiber optic assembly head moves relative to the web via $x-y$ translation stages overhead. Laser, translation stages, web stepper and tensioning motors are computer controlled, and registration for subsequent scribing and screenprinting steps is done with optical detector inputs to the computer. After a submodule is scribed on the scribing platen, a new submodule is rolled out on the platen for scribing and the just scribed web is rolled-up onto the take-up roll.

(4) Screen printing of insulator inks over scribe lines.

The next step in the manufacturing process is to screen print insulator inks over the scribe lines prior to TCC deposition to prevent electrical shorts. At the same time, an additional insulation ink line is printed on the a-si parallel to, and a short distance away from (about $0.5 \mathrm{~mm}$ ), the line printed over the scribe line. This second insulator line acts as a laser beam-stop for scribing an open in the TCC layer. The inks used are low outgasing so as to not adversely affect the deposition and conductivity of the TCC layer. The operation of the roll-to-roll screen printer involves stretching the scribed a-si coated web over a printing platen and under a printing screen patterned to match the scribe lines. The platen is free to rotate under the web, in order to align the screen and scribe patterns. A commercial screen-printing machine has been modified to print the desired pattern on the web upon computer command. 
After submodule printing, the next submodule is rolled out for printing, and the just-printed submodule enters an air-drying oven to cure the inks. After leaving the oven, the printed web is rolled-up onto the take-up roll. All operations are computer automated.

(5) Zno transparent conducting contact (TCC) deposition.

Next, the scribed a-si web, printed with insulator ink, is coated with zno top contact material to a thickness of around $4000 \mathrm{~A}$. The zno depcsition is done by thermal CVD, using diethyl zinc as the feed material. The decomposition and deposition takes place at around $150 \mathrm{C}$, and non-substrate surfaces are cooled with water lines to reduce undesired coatings and powder inside the chamber. In addition to the zno deposition chamber, there are plasma cleaning chambers to remove contamination occurring during the scribing and insulator printing steps. The zno TCC coater also uses the multichamber design with an outer can as pumping plenum. Like the other deposition chambers and major components of the scribing and printing stations, the zno deposition system was designed and constructed by ITFT. The outer can dimensions are $10^{\prime}$ 'long $\times 4^{\prime}$ wide $\times 3^{\prime}$ high.

(6) Laser scribing of the open in the znc top contact.

In the next manufacturing step, an open is scribed in the zno top contact with a laser beam. The beam follows down along the top of the second, parallel insulator ink line. This ink 1 ine acts as a beam stop for the laser beam, to prevent thermal damage to the deposited layers below. The three laser operations, scribing the a-si/Al, scribing the zno, and welding the Al to the top conductor, creates the submodule series electrical interconnect: an open in the bottom layer, an open in the top layer, and a short or shunt in between the two opens.

(7) Screen printing of the silver conducting ink.

The next manufacturing step is to screen print Ag conducting ink to make contact between the weld interconnect region and the adjoining cell's TCC zno. This printing is done to bridge over the insulating ink line on the initial scribe (with a parallel bridging strip and/or perpendicular grid lines), and to present a target strip in the region between the two closely parallel insulator ink lines for laser welding the interconnect shunts.

(8) Laser welding of the Ag ink/zno to the Al layer to form the interconnect shunt.

Next, the Ag conducting ink is bonded to the aluminum layer underneath by the laser welding process. The laser beam impinges onto the Ag ink, driving Ag metal through the $\mathrm{zno}$ and $\mathrm{Si}$ to make contact with the underlying Al. Actually, what occurs is the formation of a conducting mixture of $\mathrm{Ag}, \mathrm{Zno}, \mathrm{Si}$ and $\mathrm{Al}$, with $\mathrm{C}$ added from the thermal decomposition of the polymer vehicle in the Ag ink. Note that the order of steps (7) plus (8) can be 
reversed with step (6). However, scribing the zno open first (prior to welding the interconnection) allows the voc to be measured for isolated cells on the module.

Busbar attachment.

Next, busbar strips are attached to the ends of submodule lengths. Current attachment methods use wet, conducting Ag ink to bond a copper busbar to preprinted conducting grid lines on the module. The Ag ink is cured to form a good electrical and mechanical contact between the busbar and module. Other busbar material consists of copper foil coated with a conducting adhesive, and is commercially available. Currently, the busbars are aligned and attached by hand to cut pieces of web, but busbars can be attached in a roll-to-roll process.

(10) Cutting submodule-sized sheets from the web.

The next step is to cut the submodule web into individual submodules, prior to encapsulation. Note that these steps (9) and (10) can be switched if busbar attachment is no more dificult with sheets than with roll-to-roll web. Automated sheet cutting can be done simultaneously ith the bus bar registration and attachment, so that re-registration of the web need not be necessary.

\section{(11) Encapsulation.}

Next, the submodule sheets are encapsulated into finished modules. (Note: submodule sheets cut from the web are used, rather than web encapsulated roll-to-roll, to insure edge-sealing on all four edges of the module). Currently, polyester/EVA flexible polymer laminate material is used as a base encapsulant for handing. The final encapsulants, for both flexible and rigid module applications, depend on the application. The modules can at this point be laminated using a standard vacuum thermal laminator. However, a web slitter/rewinder/laminator can be used in a potentially more cost effective manufacturing process, based on prototype experiments using a small, pressureheated, nip-roller laminator. The module completion steps (9)(11) are the most labor intensive parts of the manufacturing process.

Photographs of the pilot-line equipment are shown in Appendix 2 .

Technology from other companies/sources upon which this process is reliant includes:

(1) Polyimide substrate with desired physical properties.

(2) Silver conducting ink, with stable bonding to the TCC surface, low contact resistance, and low bulk resistivity. There is a wide variation in the contact resistance properties of a given Ag ink to a given TCO TCC surface. 
SERI Manufacturing Initiative--Phase 1

Task 2 .

Identify and describe:

1) Potential module/cell manufacturing processes (or changes in existing processes) that can lead to improved performance, reduced manufacturing costs, and significantly increased production; and

2) The long range potential benefits of these improved processies.

To reduce module production costs, increase module performance and expand U.S. commercial production capabilities, a number of process improvements and modifications are envisioned. These improvements are designed to reduce material, labor, and capital costs as well as improve production throughput, device efficiency and module stability. Specific modifications are delineated below.

A major component of the material cost is the polyimide substrate $(\$ .80 / f t 2)$. Developing the process to allow use of 1 mil polyimide will cut that cost in half. The current preference for front transparent, outdoor encapsulant (Dupont Tefzel) is of the same order of cost $(\$ .80 / f t 2)$. We envision development of $a$ front encapsulant incorporating multilayers of lower cost material.

A-Si deposition, zno deposition and module laser scribing are the slowest steps in the manufacturing process. Research to increase deposition rates for the a-Si and zno layers are needed to improve throughputs for these deposition steps. Magnetic enhancement of the plasma in a-si deposition promises to increase deposition rates and increase film quality and stability. Multibeam fiber optic delivery systems for laser scribing are designed to keep throughput rate compatible with the a-si and zno depositions. However, mechanical scribing systems are an attractive alternative, and promise even higher throughput than multiple laser beams.

Device efficiency and stability will be increased with the transition to tandem cells and as production experience increases. It is anticipated that module power will increase from the current $5 \mathrm{Wp} / \mathrm{ft} 2$ to $8 \mathrm{Wp} / \mathrm{ft} 2$, following the current situation with a-Si on glass superstrates.

Two alternative manufacturing processes are described below:

Alternative Manufacturing Process A:

Procedures Involving Wet-Etching and sheet-Handing steps.

In addition to improvements in the rate-limiting steps, alternative flow paths in the manufacturing process are 
envisioned which will improve throughput and yield (refer to Fig. 1 and Fig. 2 ).

A new module manufacturing process has been envisioned that allows all the deposition steps to be completed, including the top TCC layer deposition, prior to any module fabrication steps. The bottom metal contact layer (aluminum, for example), the amorphous silicon a-Si:H p-i-n layers, and the top TCC layer (zno for example) are done in roll-to-roll deposition chambers. With the roll-to-roll deposition steps completed, the product at this stage is one large cell, 12" wide and $2400^{\prime}$ 'long.

Note that depositing the zno onto a pristine a-si surface eliminates the need for the web cleaning steps used in the present baseline process. Thus a single-pass, rather than double-pass, of the web through the zno deposition machine is necessary. This gives a significantly improved throughput.

Also, with the TCC completed before module manufacture begins, the requirement of roli-to-roll registration is removed. The roll of cell material can be cut into sheets between any subsequent steps, and corner- or hole-registered for subsequent scribing and printing steps. The primary advantage of cutting the web after zno deposition is to take advantage of existing sheet handling equipment in related industries, while retaining the advantages of roll-to-roll depositions. Registration times for sheets using mechanical registration appear to be faster than for roll-to-roll registration with optical detectors.

Amorphous silicon coated web usually exhibits curl due to compressive stresses in the film (created by differences in the thermal expansion coefficients between the a-si coating and the polyimide substrate). For ease in handling sheets of web cut from the roll, it will probably be necessary to eliminate web curl, e.g. by roll-to-roll lamination of the polyimide web to a low-cost polymer backing used as a stiffener. The deposition of zno TCC counteracts the curl created by the a-si deposition, flattening the web and aiding the lamination process. A suitable polymer backing stiffener would be EVA, which is inexpensive, and can be laminated to polyimide. As an alternative to lamination, an anti-curl pretreatment deposition on the web back side can be done when the front side of the web is metalized. This would, however, curl the web in tension, making subsequent a-si deposition more difficult, particularly if polyimide web thinrer than 1 mil is used.

Once the roll of coated polyimide has curl eliminated, the roll can be cut into module-sized sheets. As the web is cut into sheets, registration holes simuitaneously can be punched into the side of the web. The use of registration holes, a method adopted in the fabrication of printed circuit boards, eliminates the need for registration Iine detectors used in roll-to-roll module fabrication. The other alternative would be to perforate sprocket holes in the continuous web, and this appears to be a less desirable solution in terms of equipment cost and debris 
Fig. 2. Alternative A-Si Thin PV Module Production Process Steps Using Wet-etching and Sheet-Handling

Step \# Production Step

Metalization of polyimide web

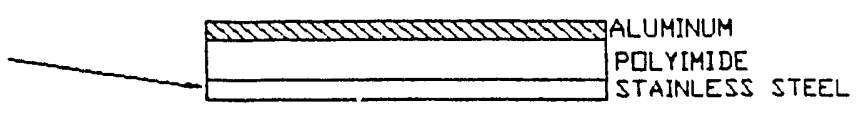

(2).

A-si p-i-n
depostion

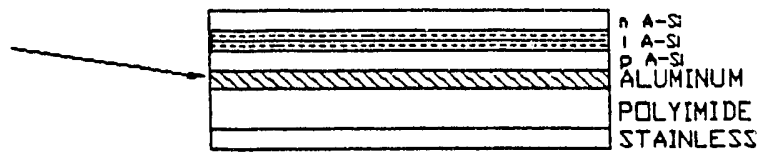

STEEL

Znd top contact deposition

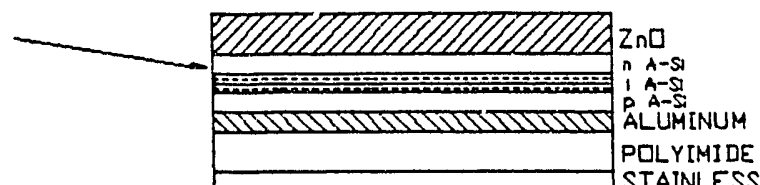
STAINLESS STEEL

(4)

(6)

Stiffening the web by lamination to backing polymer

Cutting the web into sheets and punching mechanical registration holes

Etching the TCC

(7)

Laser scribing of A-sirmetal coating

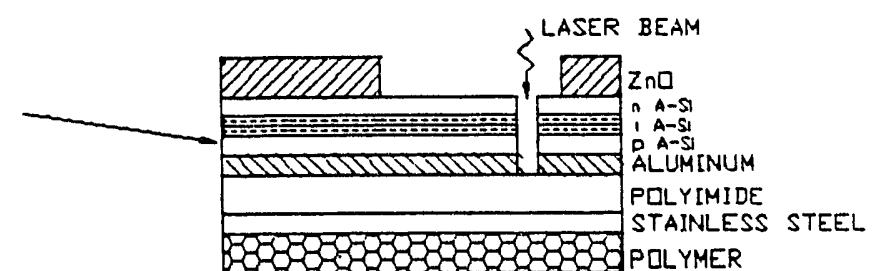

(8)

Screen-printing of insulator ink over scribe region

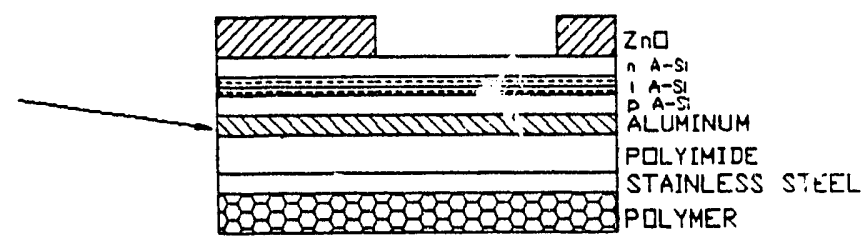

(9)

Screen-printing of Ag conducting ink

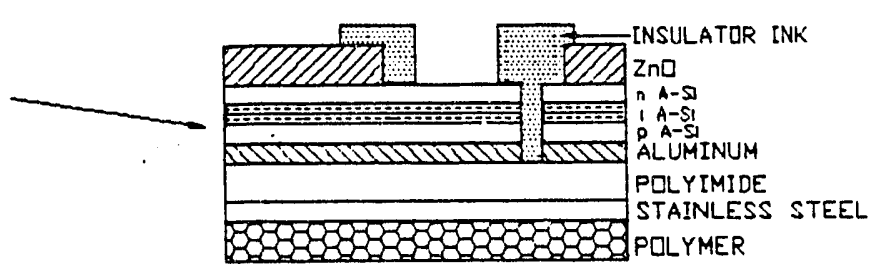

(10)

Laser welding of Ag ink/Zna
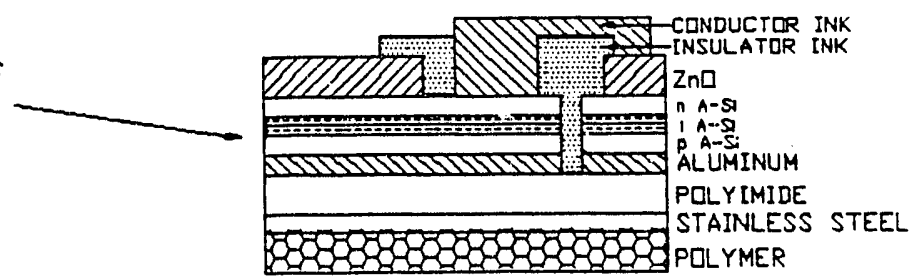

(12)

Busbar attachment

Encapsulation

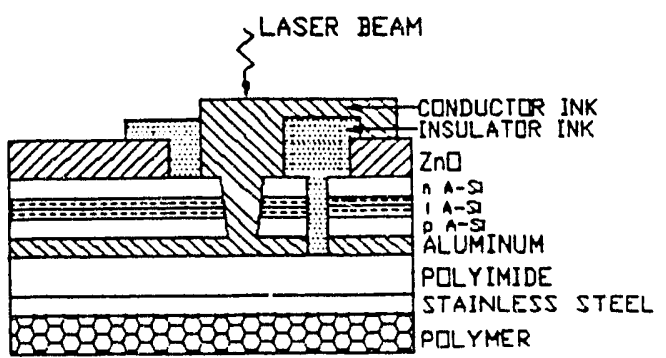

11. 
creation.

Using conventional sheet handling technology adapted from the screen-printing industry, a module sheet is placed on the registration pins on a screen-printing platen. As a vacuum pulls the sheet flat, the regisiration pins are retracted below the platen for printing. A water-soluble etchant gel is printed onto the zno TCC coating surrounding the scribe lines, either in a single wide strip, or two parallel strips. The printing screen is patterned to define individual cells by removing zno in narrow strips around the cells. At the same time, using the same patterning screen, designs for integral bypass diodes can be etched into the zno top contact surface. This method of patterning the zno (by printing an etching gel) is preferred to the alternative of printing the reverse- or negative-image with etch-resist ink (the strips of zno defining the cells are removed by immersing the etch-resist coated module in an etching bath). stripping the greater area/amount of etch-resist also requires solvents such as toluene, and, in general, disposal of the etchresists and required solvents presents a greater environmental problem than with using water-soluble etching gels.

After a suitable time for reaction $(15-30 \mathrm{sec})$, the etchant gel is removed by water-spray cleaning. The wet, etched sheets are dried on a belt-dryer, as are subsequent printing steps. The etching gel cleaning solution is pH neutralized and solids are allowed to precipitate in a settling tank. Cleaning water is filtered and recirculated in the primary cleaning stages, to minimize environmental impact.

Next, the module sheet is placed on the registration pins on a scribing platen. A vacuum pulls the sheet flat onto the platen, and a laser or mechanical scriber patterns the coated
module sheet, cutting through the 2 no, a-si and Al layers down to the polyimide substrate.

Next, the module pieces are screen printed with an insulating ink. The insulating ink covers the scribe pattern in the amorphous silicon exposed by etching and also overlaps slightly onto the TCC zno of the adjoining cell, to cover any shunts in the area between the scribe and that cell's $\mathrm{Zno}$. A line of insulating ink, parallel to the insulating ink covering the scribe region, is simultaneously printed over a strip of the amorphous silicon overlapping the cell's own TCC zno. This second series of insulating ink lines guarantees an open in the top contact. An open in the top contact, along with the open in the Al created by scribing and the interconnect weld/shunt to be described, is necessary to create a series interconnect between cells. Between the two insulating ink lines is a region of bare amorphous silicon. This is the region where the conducting Ag ink is to be printed and welded to create the cell interconnect shunt. As an alternative to leaving a single, wide bare silicon region exposed by etching, a central strip of unetched TCC zno can be left between two strips of amorphous silicon exposed by etching and covered by the aforementioned insulating ink prints. 
This unetched TCC zno reduces the amount of conducting ink necessary to create the interconnect shunt to be discussed.

Next, conducting Ag ink lines are printed to make contact between the weld interconnect region and the adjoining cell's TCC zno. These conducting ink patterns bridge over the insulating ink strip covering the scribe through the Al layer. If a single, wide etched amorphous silicon strip is exposed, it is necessary to print a conducting ink line between the two insulating ink strips along the scribe. If an unetched TCC strip is left between the insulating ink strips, a continuous conducting ink strip between the insulating ink strips is not necessary. The Zno strip can be welded to the Al layer and create the conducting shunt. A silver ink grid is still necessary to bridge over the insulator ink to make contact with the adjoining cell's TCC. The connection lines to make contact with the busbars are printed at this time also.

To create the interconnect shunt, it is necessary to create a path of minimum resistance in-between the open in the TCC top contact and the Al bottom contact. A laser has been used to weld a Ag conducting ink strip to the Al bottom layer. The laser weld can be effected by directing a focussed beam down onto the coated web or by shining the beam through the polyimide onto the backside of the deposited Al. By shining through the web, less laser power is needed to weld the $\mathrm{ZnO}$ and $A l$ directly together, without using the Ag ink. Note that it is easier to weld sheets cut from the web by shining the laser beam through the back, rather than using roli-to-roll web. With sheets there would be no scraping damage to the web as there might be with dragging a coated web across the scribing platen. Alternative welding methods include electronic and ultrasonic spot-welding.

Next, copper busbars are attached to the modules, at the ends of the series string of cells. Current attachment methods use wet, conducting Ag ink applied to the busbar to contact preprinted conducting grid lines on the module. The Ag ink is cured to form a bond between the busbar and module. spot-welding techniques are also under test. For corrosion resistance, tinned, copper-foil strips are attached by soldering to the busbars, for external circuit connection.

Shunt removal is obtained by reverse biasing the modules, thereby heating shunt regions and changing the conductive properties of the $\mathrm{zno}$ to an insulator.

Finally, the completed modules are encapsulated, with a border of flexible encapsulating material surrounding the four sides of the module. As the current encapsulant (Tefzel) is quite expensive, a multilayer substitute is an option for cost reduction. Whatever encapsulating materials are used, the encapsulating layers should have the following properties, on the illuminated side of the modules, in addition, of course, to high optical transparency:
1)
the outermost
layer should be scratch-and
UV-damage- 
resistant;

2) the next layer should be a UV-light barrier to protect UVsensitive layers underneath (a film can be UV-damage resistant, but not a UV-barrier, and transmit uv light through it to layers below);

3) the next layer should be a vapor barrier;

4 ) the innermost layer should be chemically non-reactive in contact with the module surface.

(The principal function of the back layer to the module is as a vapor barrier, and as the place where the busbar wires are connected to an external junction-box). Some of these layerfunctions can be filled with one material. For example, Dupont's Tefzel is scratch-resistant, UV resistant, a UV barrier and a vapor barrier. EVA (ethylene vinyl acetate) is generally accepted as a good material to place in contact with the cell surface.

In summary then, the steps identified in this new, proposed method for module manufacture are as follows (see Fig. 2):

(1) metalization of the web:

(2) deposition of the a-si:H device;

(3) deposition of the transparent conducting contact (TCC);

(4) treatment of the web to eliminate curl (e.g. by stiffener lamination, or anti-curl pretreatment deposition);

(5) cutting the veb into sheets and punching mechanical registration holes;

(6) etching the TCC around the metalization layer scribe-area, creating an open in the TCC and forming integral bypass diode pads;

(7) scribing the metalization layer;

(8) printing an insulating ink over the scribe lines (to prevent cell shorting), and over the region of exposed a-si:H surface (to protect the open in the TCC);

(9) printing a conductor ink to bridge over the insulating ink line, and to complete integral bypass diodes;

(10) welding the conducting ink to the metal back contact of the cell (i.e. creating the interconnect shunt);

(11) attachment of busbars to the module ends, and shunt removal;

(12) encapsulation of the module with suitable encapsulant glazing materials.

Specifically, these new process steps differ from the present pilot-line process in the following ways. Referring to Fig. 2, and comparing it with Fig. 1 of the baseline case:

(a) For step (3), rather than scribe the a-si/metal layers, the zno TCC would be deposited. This would mean all depositions would be completed before further submodule fabrication, avoiding handling and contamination.

(b) For step (4), the web is treated to eliminate curl.

(c) For step (5), the fully coated web would be cut into sheets of finished module size, and registration holes punched 
into the edges of the sheets.

(d) For step (6), the Zno TCC would be patterned with an etchant gel developed for this process, and washed clean. This is a wet step in the process, although the gel developed is water-soluble.

(e) For step (7), the submodule sheet is laser scribed in a method similar to the original step (3). Note that it may be possible to switch steps (6) and (7).

(f) For step (8), insulator inks are printed over scribe lines, in a method similar to the original step (4). However, a beamstopping line is not necessary, since the zno electrical open will not be laser scribed, but will be created by the etching process in the new step (6) above.

(g) For step (9), conducting Ag lines are printed in a method similar to the original step (6) in Fig. 1 .

(h) For step (10), the Ag ink/Zno is welded to the Al back contact in a method similar to the original step (7).

(i) For step (11), busbars are attached in a manner similar to the original step (10), except here submodule sheets are used rather than roll-to-roll web. Actually, the original steps (9) and $(10)$ can be switched if busbar attachment is no more difficult with sheets than with roll-to-roll web.

(j) For step (12), the submodules are encapsulated into modules as in the original step (11) in Fig. 1 .

Note that steps (6) and (7), the metalization scribe and TCC etch steps, may be reversible. Scribing before etching allows the etch to clean up scribe debris and undesired shunt path layers. However, the etchant gel or bath may attack the Al too vigorously, undercutting the a-si overlayer adjacent to the scribe, or leave a residue that corrodes the Al over time. The cleaning steps would have to remove, and/or $\mathrm{pH}$ neutralize, all residue.

In any case, if it is possible to scribe before etching, the scribe line provides a precision mark for opto-electronic alignment. This would be important if micro-registration is required, even with the mechanical registration holes.

There are advantages in the above alternative process: all three coatings are deposited in sequence, and registration of sheets would be simpler than roll-to-roll web. However, $a$ wet etching process is necessary, and specialized sheet-handling equipment would be needed for other than the lamination process. ITFT is currently working with personnel in the ISU school of Industrial Engineering under subcontract to develop a manufacturing process model to evaluate the relative costs of the various alternatives, using the manufacturing simulation program SIMAN IV (see Appendix 3). 
Alternative Manufacturing Process B: Procedures involving wet-etching and roll-to-roll fabrication steps.

Actually, the process described above, completing the depositions prior to module manufacture, can also be done rollto-roll, rather than as cut sheets. This process, shown in Fig. 3 , is an alternative roll-to-roll process and requires the least amount of new equipment, as compared to sheet handling. A rollto-roll washing and drying step is required. Optical detectors could align the web on the etched region preparatory to scribing, although more precise registration would be allowed if scribing could precede etching, and web alignment done on the scribe lines. Alternatively, just the edges of the web could be scribed, preparatory to etch-printing. The etch-print alignment would be done on the edge-scribes, and the etching would not be near them. The full module scribe patterning, done after etching, would realign on these preliminary scribe marks. An extra process step through the scriber would be necessary, but it would be rapid, requiring a $1 / 2$ " long scribe on both sides of the web, for each module length. Screen-printed insulator ink registration marks are also a possibility. Printed registration lines would have higher throughput, but poorer resolution: typical laser scribe lines are $2 \mathrm{mil}$ wide, whereas $10 \mathrm{mil}$ screenprinted registration marks are standard.

The processing of modules by roll-to-roll etch-patterning would share many of the details previously mentioned for processing by sheet etch-patterning. The steps identified in this second new, proposed method for module manufacture are as follows (see Fig. 3 ):

(1) metalization of the web;

(2) deposition of the a-Si:H device;

(3) deposition of the transparent conducting contact (TCC);

(4) etching the TCC around the area of the metalization scribe, creating an open in the TCC and forming integral bypass diode pads ;

(5) scribing the metalization layer;

(6) printing an insulating ink over the scribe lines (to prevent cell shorting), and over the region of exposed a-si:H surface ito protect the open in the TCC);

(7) printing a conductor ink to bridge over the insulating ink line, and to complete the integral bypass diodes;

(8) welding the conducting ink to the metal back contact of the cell (i.e. creating the interconnect shunt);

(9) attachment of busbars to the module ends, and shunt removal (by heating and reverse-biasing, and/or by electrochemical methods);

(10) cutting the web into sheets;

(11) encapsulation of the module with suitable encapsulant/glazing materials.

Specifically, these new process steps differ from the present pilot-line process in the following ways. Referring to 
Fig. 3' Alternative A-SI Thin Fllm PV Module Production Process Stefs using Wet-etching oind Roll-to-roll Handling

Step \#

(1)

(2)

(3)

(5)

(6)

(7)

(8)

(9)

(10)

(11)

Production Step

Metalization of polyimide web

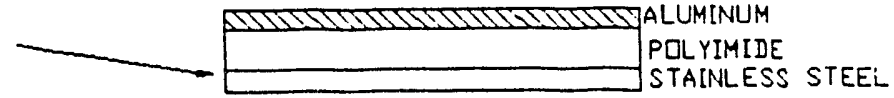

$A-S i p-i-n$

depostion

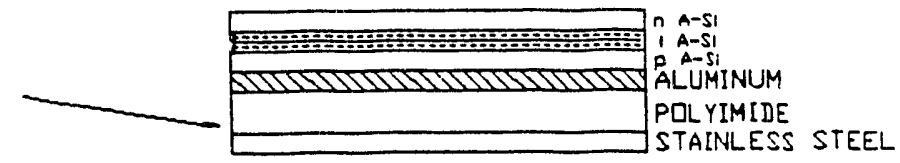

Zna top contact deposition

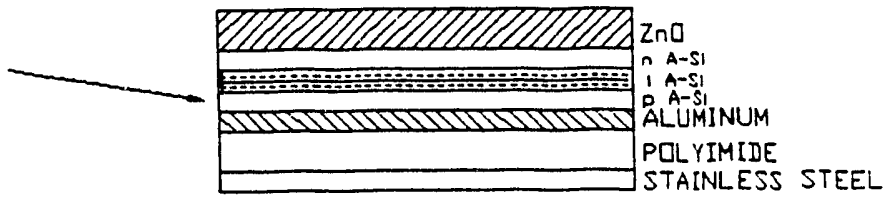

Etching the TCC
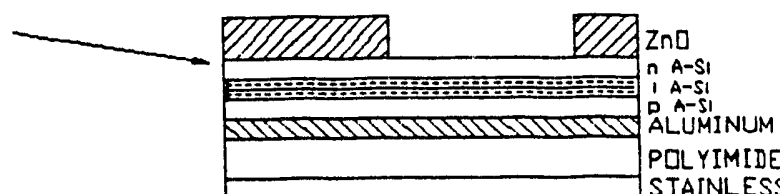

STEEL

Laser scribing of A-Si/metal coating

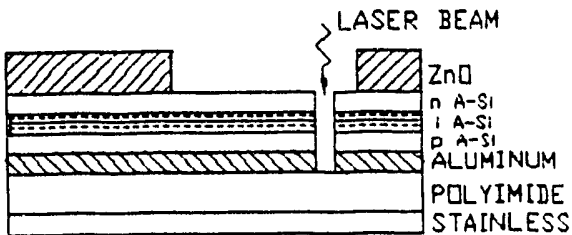
STEEL

Sereen-printing of insulator ink over scribe region

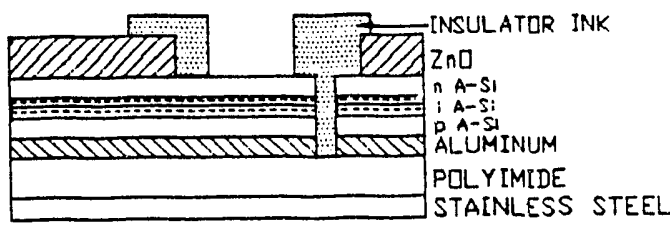

Screen-printing of Ag conducting ink
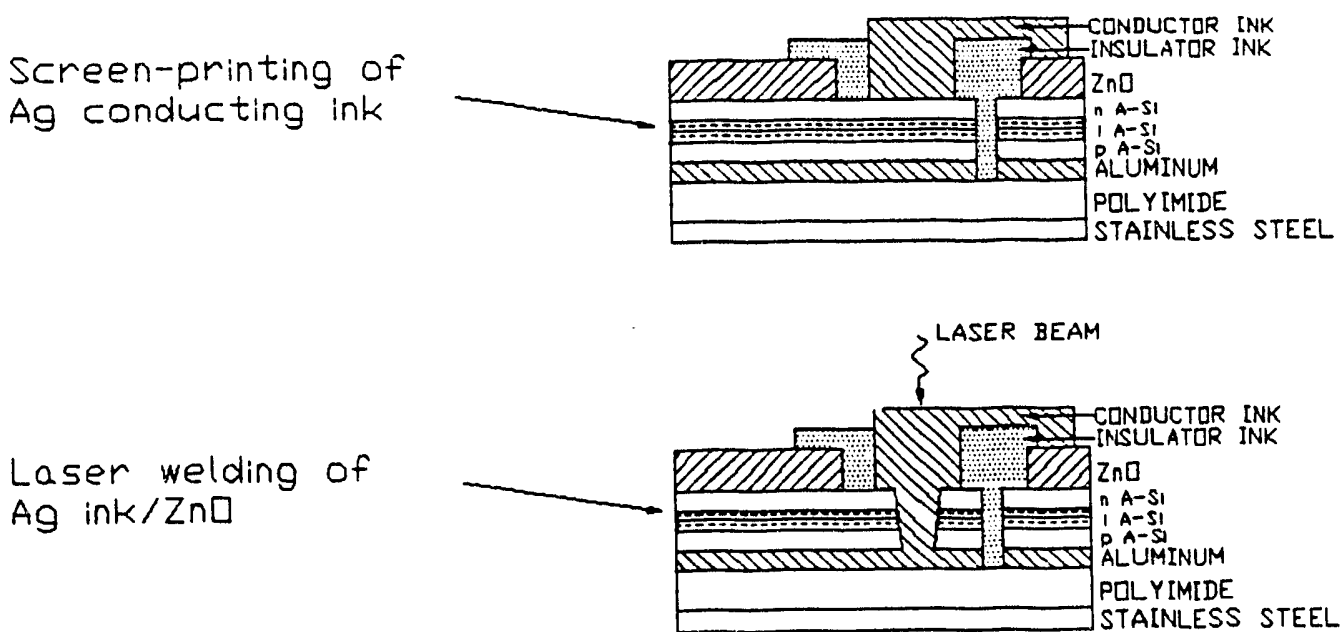

Busbar attachment

cutting web into sheets

Encapsulation 
Fig. 3, and comparing it with Fig. 1 of the baseline case:

(a) For step (3), rather than scribe the a-si/metal layers, the Zno TCC would be deposited. This would mean that all depositions would be completed before further submodule fabrication, avoiding handing and contamination.

(b) For step (4), the zno TCC would be patterned with an etchant gel developed for this process, and washed clean. This is a wet step in the process, although the gel developed is wate: soluble.

(c) For step (5), the submodule pattern is laser scribed in a method similar to the original step (3). Note that it may be possible to switch steps (4) and (5).

(d) For step (6), insulator inks are printed over scribe lines, in a method similar to the original step (4). However, a beamstopping line is not necessary, since the zno electrical open will not be laser scribed, but will be created by the etching process in the new step (4) above.

(e) For step (7), conducting Ag lines are printed in a method similar to the original step (7) in Fig. 1.

(f) For step (8), the Ag ink/Zno is welded to the Al back contact in a method similar to the original step (8).

(g) For step (9), busbars are attached in a manner similar to the original step (9).

(h) For step (10), the web is cut into sheets in a manner similar to the original step (10).

(i) For step (11), the submodules are encapsulated into modules as in the original step (11) in Fig. 1.

The long range potential benefits of these improved processes can be projected by using a manufacturing simulation program, such as SIMAN IV. The results of these simulations are summarized below, and discussed in detail in Appendix 3.

Increased automation is envisioned in the last several steps of the process to reduce labor costs. Simulations with the SIMAN IV program indicate that the cost/ft2 module using the current or baseline manufacturing methods (schematically shown in Fig. 1) is given by $\$ 5.67$ (see Appendix 3 ). Simulations with SIMAN IV for the alternative process involving print-etching and sheethanding, indicate that the cost/ft2 are given by $\$ 5.84$. Finally, simulations for the alternative process using printetching and roll-to-roll processing indicate that the cost/ft2 are given by $\$ 5.66$. 
SERI Manufacturing Initiative--Phase 1

Task 3 .

Identify and describe the problems that may impede the achievement of the potential benefits described in Task 2 . Also, identify all generic problems for which solutions are sought (e.g. encapsulation).

(1) To institute the alternate manufacturing flows, an appropriate etching process must be developed to remove $\mathrm{Zno}$ for cell patterning. Suitable etching materials, printing screen emulsions, etching patterns and processing machinery need to be developed.

(2) At some point between the roll-to-roll TCC deposition, and the final encapsulation of submodule sheets into finished modules, the web roll must be cut into sheets. We have indicated that the best point to do the sheet handling rather than roll-toroll is immediately after the TCC deposition. With adequate registration (less than $0.005^{\prime \prime}$ ) using pin-holes in the cut sheets and guide pins in the platens, the time-consuming roll-to-roll registration on $0.002 "$ wide laser scribe lines can be avoided. Also, sheet handling avoids queue build-up between process equipment stages as occurs with roll-to-roll processing, and avoids stress damage caused by stretching web at high tension over a platen. However, suitable sheet cutting, hole punching/drilling, and handling equipment needs to be developed. Rapid alignment/positioning of submodule sheets needs to be developed. As for flexible printed circuit boards, punched hole registration may be adequate, but secondary optical registration may also be necessary in conjunction with alignment pin-holes.

(3) Throughput must be increased in the a-si deposition step. There are two basic ways to increase the throughput in this process-rate limiting step. One way is to construct a second, parallel output a-si deposition system. A second way is to increase the a-si deposition rate. The first way necessitates a considerable infusion of new capital, whereas the second way does not.

(4) Improvement in the throughput of the zno transparent conducting contact (TCC) step is required. Like the a-si deposition, the zno deposition is a rate limiting step. Again, like the a-si deposition case, there are two basic ways to increase the throughput in this process-rate limiting step. One way is to construct a second, parallel output zno deposition system. A second way is to increase the zno deposition rate. The first needs considerable new capital, whereas the second way does not.

(5) Higher throughput in the laser scribing and welding processes is required to reduce capital and production costs in those steps. Laser scribing and welding of cell interconnects 
are "linear" processes in that the laser beam produces a scribed or welded line on the module. By contrast, screen-printing is an "areal" process in that an area of material is printed at one time. Higher throughput in the scribing and welding processes can be achieved either by having multiple laser beams to process more than one scribed or welded line at a time, or by using alternate scribing and welding methods that have higher throughput and/or lower capital cost.

(6) For the bottleneck process steps (a-si deposition, zno deposition and laser scribing/welding) the tradeoff in parallel systems (e.g. more than one 13" wide-web a-si deposition system) versus a larger capacity, higher throughput machine (e.g. using 1 meter wide web), needs to be examined. Capital costs, repair or "down" times and scaling effects of equipment size need to be considered in determining the lowest cost per watt or cost per $\mathrm{m} 2$.

(7) Computer automation is a key to the success of any of our module manufacturing processes. A significant number of automated processes need to be solved or optimized. Computer process times and algorithms require continual updates and refinements. Certain of the manufacturing stations have operational programs (e.g. scribing and printing), whereas others do not (e.g. busbar attachment).

(8) Reductions in flexible substrate cost must be obtained. Such cost reductions could be obtained by development of a lowcost, high-temperature polymer.

(9) In the current, baseline process, reduction of the outgasing effects from the insulating inks on the subrequent zno deposition is needed to improve performance of the flexible modules.

(10) The process for producing the series interconnect by using semi-flexible, non-brittle Ag conducting inks must be improved to reduce series resistance in the full modules. Both Ag ink properties (ink adhesion, contact resistance to the zno surface and bulk resistivity), and appropriate contact grid design need to be considered. Ag ink properties will also affect the construction of bypass diodes.

(11) A lower cost top transparent flexible polymer encapsulant must be developed. Current available encapsulants suitable for outdoor terrestial power applications are expensive.

(12) In the current, baseline process, web wander or skew is controlled by collar-guides on the rollers. The ability to control web-skew is limited by this method, even with web-guide actuators.

The generic problems for which solutions are sought include the following:

(1) Stability of the devices must be improved. Improvements in 
material quality, particularly in the i-layer, can improve stability somewhat. However, most improvement in device stability has been obtained by using appropriate device construction, e.g. p-layer vs. n-layer window, and tandem p-i-n$p-i-n$ vs. single-junction $p-i-n$ device.

(2) Passivation layers are needed for the top contact/transparent encapsulant interface, for corrosion resistance of the busbars under the encapsulant, and for the generic problem of hermelic sealing of flexible electronic devices.

(3) Modeling of the reaction rate and plasma properties of the a-si deposition process is needed, so as to increase the deposition rate in a controlled manner.

(4) Deposition and control of electronic and optical properties of zno is common to many thin-film photovoltaic devices (e.g. aSi, CIS, CdTe). A thorough understanding of growth chemistry and doping properties for large area deposition of zno is needed.

(5) Shunt defects in thin-film photovoltaic devices is a common problem. Methods to eliminate or reduce them include thermal and electrical annealing, and electrochemical etching/deposition. Effects of remaining shunt defects can be minimized by appropriate module design. Both material processing and module design need further refinement. 
SERI Manufacturing Initiative--Phase 1

Task 4 .

Identify and describe the approaches which can be taken for the solution of those problems identified in Task 3 , including timeand cost-estimates for achieving those solutions.

Three different module manufacturing paths were outlined in Task 1 and Task 2. The first such path is based on the 13 " pilot-plant, with modification of certain steps and equipment from earlier work done at $3 M$ on SERI contract. Some development has been done on the alternate manufacturing paths, but no equipment has been built and the process is conceptual. However, the critical step, to pattern the zno TCC with a screen printable etching gel, has been performed. The perceived benefits of depositing zno directly onto pristine a-si for maximum device quality are considerable. The problems with a wet etching process are present but not insurmountable. The problems of developing equipment to handle pieces of submodule material for processing and encapsulation have solutions that already exist in the printing industry: designs seem straightforward. Nevertheless, to do an adequate study of these alternative module manufacturing steps, equipment designs and costing need to be undertaken, and prototype equipment needs to be constructed and operated. The anticipated increases in throughput rate, decreases in capital equipment and operating expenses, and increases in reliability need to be incorporated into production models for their verification. Simulation studies done using SIMAN IV will indicate the best methods to process cut-web pieces in the steps leading to final encapsulation.

Approaches to solve the problems identified in Task 3 for the alternate manufacturing flows (see Task 2) are discussed below:

(1) To institute the alternate manufacturing flows, an appropriate etching process must be developed.

Development of etching gels to pattern the TCC zno coating for cell definition and interconnection by screen printing wili be required. Also, screen emulsions need to be found that are stable to attack by the etching gel; equipment needs to be designed and built to wash off the etchant; and methods of disposal of the waste liquids from this wet process need to be environmentally safe. A first effort, screen-printable etching gel has been developed from commercially available constituents, to pattern the zno. A candidate etch-resistant emulsion has been identified to pattern the screen. The gel is water soluble, so that the waste-liquid from the wet process is not solvent-based, but essentially is an aqueous solution. Machinery for zno removal has been designed but not built.

Based on information obtained from vendors and our own 
engineering analysis, cost and time estimates for etching equipment are approximately $\$ 5,000$ initial capital cost; $\$ 5,000$ engineering, installation and shake-down cost; and 6 weeks startup time after arrival of the equipment. These costs are part of the printer system and consist of a water-spray cleaner integrated into an existing system, and would not greatly affect the estimated value $(\$ 86,000)$ used in the manufacturing simulation cost for the printer. The cost of the research and development for the process is $\$ 100,000$ over 2 years.

(2) In order to reduce labor costs in the final process steps, designed for the processes.

Equipment for automated rolling-off submodule material from a web; registering submodule lengths of web; cutting off web lengths; punching registration holes; attaching busbars; handling sheets for scribing, printing and welding; and sheet developed. Fortunately, this is an area where suitable equipment already exists (or can be modified) to handle roll-to-sheet processing. The printing industry is one source of such expertise. The polyimide sheets may exhibit too much curl to handle, may be too "floppy" to avoid creasing-damage, or may otherwise need back lamination with a low-cost plastic sheet stiffener or back vacuum-coating with an anti-curl layer, prior to cutting the web into sheets. Evaluation and selection of a registration process will drive much of this development.

Based on information obtained from vendors and our own engineering analysis, cost and time estimates for a sheet-cutter are approximately $\$ 20,000$ initial capital cost; $\$ 12,500$ engineering, installation and shake-down cost; and 6 weeks startup time after arrival of equipment. Similar costs and times for the registration-hole punching equipment are: $\$ 15,000$ capital cost; $\$ 12,500$ engineering costs; and 6 weeks start-up time. Costs and times for busbar attachment are: $\$ 30,000$ capital cost; $\$ 12,500$ engineering costs; and 6 weeks start-up time. Cost and time estimates for the automatic sheet feeders (needed on the printing; scribing, hole punching, and busbar attachment stations) are $\$ 40,000$ initial cost each; and 6 weeks start up time. Finally, costs and times for encapsulating equipment are: $\$ 6,000$ (Eor two systems operating in parallel) capical cost; $\$ 12,500$ engineering costs; and 6 weeks start-up time. Associated $R \& D$ costs are $\$ 400,000$ over 2 years.

(3) Throughput must be increased in the a-si deposition step.

The most cost effective way of achieving this is to increase the deposition rate of the a-si i-layer. Care must be taken when doing this to minimize powder formation which would lead to shunt defects. Our primary technical approach to accomplishing this is to pursue the use of magnetic enhancement of the plasma for deposition of a-si i-layers. A range of powers, gas flow rates and magnetic field patterns are planned. The effects on 
deposition rate, uniformity and powder generation will be investigated.

Estimated associated $R \& D$ costs and times: $\$ 300,000$ over 3 years.

(4) Improvement in the throughput of the zno transparent conducting contact step is cequired.

zno deposition rate may be increased by raising the substrate temperature. However, it is critical to maintain proper doping levels to insure adequate conductivity. Alternative dopant feedstocks and variations in the inflow gas manifolding will be evaluated for their ability to maintain conductivity at higher deposition rates. In the zno TCC deposition system constructed, several plasma and chemical vapor etching/cleaning in-line stages are provided to prepare the p+ layer for zno deposition by CVD. Process development to minimize the time needed for these steps will be performed. In particular, zno deposition on a pristine a-si coated web may preclude need for. a predeposition cleaning.

Estimated $R \& D$ costs and times: $\$ 200,000$ over 2 years.

(5) Higher throughput in the laser scribing and welding processes is required to reduce capital and labor costs in those steps.

To this end, we have developed a multiple-beam $1064 \mathrm{~nm}$ fiber optic laser-scribing and welding system with minimum spot size consistent with laser power densities allowable in fiber transmission. The single-beam laser scribing system was capable of 50 micron spot size using an open beam. Using fiber optics, we have managed to scribe a 70 micron wide line in an a-Si/AI coating with a single fiber. Using beam splitting, we have built a 4 fiber optic beam system for laser scribing at $1064 \mathrm{~nm}$, using a Q-switched YAG laser nominally rated at 15 W TEM $(00)$.

A second alternative which must be evaluated is the development of mechanical scribing methods. Scribing blade methods have been examined and appear feasible. Electro-chemical scribing and ultrasonic engraving techniques are also possibilities, particularly for cutting the zno open on top of insulator lines in the present baseline roll-to-roll process. Tolerances for scribing through a 1 micron thick coating without cutting deeper than 5 micron are necessary (polyimide film thickness is $50+-5$ micron, and printed insulator lines are typically $20 \mathrm{micron}$ thick).

Alternate, high throughput methods of establishing welded shunts in cell interconnects include spot welding the Al bottom contact to the zno top contact of the adjoining cell, via the Ag ink grid lines. Both electronic- and ultrasonic- spot welding techniques need evaluation. 
Estimated $R$ \& $D$ costs and times: $\$ 100,000$ for 1 year, each, for the scribing and welding processes.

(6) To examine easing the problems of bottleneck steps, the manufacturing simulation program, SIMAN IV, will be used to evaluate the universe of alternatives.

Manufacturing simulation is an ongoing process (ITFT has its own copy of SIMAN IV). Data gathered from manufacturing experience will be used as inputs to the program, whose algorithms will be updated as changes in the manufacturing process are made.

Yearly simulation expenses (labor) of $\$ 10,000$ are expected.

(7) Computer automation of manufacturing processes needs to be optimized.

ITFT needs a full time motion-control specialist, familiar with hardware and software of automation equipment, and having the ability to write custom programs in a structured format.

Yearly expenses of $\$ 100,000$ are expected for 3 years.

(8) Substrate is a major component of the material cost and must be reduced.

To accomplish this, a process modification must be developed to allow use of 1 mil or thinner polyimide substrate. various thicknesses of polyimide will be used in the deposition systems to determine the lower limit of polyimide thickness which can be used without suffering defects due to physical distortion. Laminating lower cost polymers as stiffeners onto the back of the polyimide after the high temperature deposition processes are completed will be studied.

Estimated $R \& D$ costs and times: $\$ 50,000$ for 1 year.

(9) Reduction of the effects from the insulating inks on the zno are needed to improve performance of the full modules in the baseline process.

Accomplishing this requires development of insulator inks that are low outgasing and resistant to environmental degradation. In the present module construction, where the zno is deposited after insulator inks are printed, low outgasing inks are crucial to preserve the most conductive stoichiometry of the oxide. Inks have been selected using the NASA database for lowoutgasing materials. Qualification of the insulator (and conductor) inks needs to be established for the terrestial and space environments. Temperature-humidity tests, and thermal expansion cycling are necessary tests for module durability.

Estimated $R \& D$ costs and times: $\$ 50,000$ for 1 year. 
(10) The process for producing the series interconnect must be improved to reduce series resistance in the full modules.

Obtaining conducting (Ag) inks that have the highest conductivity, make low resistance contact with the $\mathrm{zno} T C C$, have weld points that are stable over time to changes in conductivity, are resistant to environmental degradation, and are curable at temperatures compatible with the other module materials is required. A variety of Ag conductive inks (two part epoxy, onepart epoxy, etc.) were examined and a promising candidate is currently being used. However, the list of possible inks that can be cured at low temperatures (less than $130 \mathrm{C}$ ) has not been exhausted. A systematic study of the conductivity of welded Ag inks needs to be undertaken. Modifying the chemistry of the conducting inks to reduce the contact resistance to the zno surface also needs to be examined. Very thin priming layers, such as indium oxide, deposited on the zno prior to Ag ink printing may be necessary to achieve optimum electrical contact. Also, appropriate grid line designs that overlap the insulator line and contact the TCC of the adjoining cell need to be examined. Of interest also is a design of Ag ink stitches perpendicular to and overlapping the insulator line, but which allow welding of a strip of zno material (in the welded interconnect region) to the underlying $\mathrm{Al}$.

Estimated $R \& D$ costs and times: $\$ 100,000$ for 1 year.

(11) A lower cost top trarsparent encapsulant must be developed.

Multiple layers of lower cost transparent polymers will be investigated as a replacement for the current high-cost materials. The envisioned multiple layer stack would have a top layer with good abrasion and UV resistance, a second layer with UV absorbing properties, a 3 rd layer with excellent moisture barrier properties and a very inert bottom layer which bonds and seals well to the cell. Some of these layer properties may be combined if the proper material can be found.

\section{Estimated $R \& D$ costs and times: $\$ 200,000$ over 2 years.}

\section{(12) Web guide must be improved to eliminate skew.}

For roll-to-roll processes, particularly for the zno deposition and subsequent stages, sprocket guide holes are possible. These are best punched into bare web substrate, but the creation of dust/debris by the punching process may create shunts (this has been observed to occur with web slitting). For the baseline process, where all scribing and printing steps are done roll-to-roll, punching of sprocket holes would be best done after a-si deposition, and before laser scribing, insulator ink printing, and TCC deposition. The roll-to-roll web skew for the metalization and a-si depositions is acceptable for these steady state, constant web motion processes. However, the zno TCC requires closer web-motion tolerance, to avoid dust build-up in process gas exit slits and to provide for uncoated, bare a-si 
strips of uniform width along the web edge. Punching sprocket holes after the a-si deposition will not create further shunts. Another possibility is to use nip rollers to grab the edges of the web and pull it taut across its width. If feasible, this would accomplish the same purpose as sprocket holes.

Estimated $R \& D$ costs and times: $\$ 180,000$ for 1 year.

Approaches to solve the generic problems identified in Task 3 are discussed below:

(1) Stability of the devices must be improved.

Our most direct approach to solving this problem is to transfer the tandem cell construction which has been developed in the laboratory, to the pilot-plant a-si deposition system by using two passes through the chamber. This requires examining the effects of reroliing the web to create tandem cells by a double-pass through the $13^{\prime \prime}$ pilot-line a-si multichamber. Coated surface contamination and shunt defect creation are two possible problems. The addition of the second junction may, however, add protection against shunt defects.

Estimated costs and times: Unknown for stability in general. For the approach here, $\$ 100,000$ for 1 year.

(2) Passivation layers are needed for hermetic sealing of flexible electronic devices.

The general approach of G. Chandra at Dow-Corning, MI, under DARPA contract 49620-86-C-0110 should be followed: a stack of planarizing, passivation and barrier layers should be tried.

Estimated $R$ \& D costs and times: $\$ 200,000$ over 2 years.

(3) Modelling of the reaction rate and plasma properties of the a-si deposition process.

Commercial modelling programs exist and need to be modified to be the basis of a-si deposition modelling studies. FLUENT (Creare, Hanover, NH), and FIDAP (Fluid Dynamics International, Evanston, IL) are exampies of such codes.

Estimated $R \& D$ costs and times: $\$ 200,000$ over 2 years, including the cost of the software.

(4) Deposition and control of electronic and optical properties of $\mathrm{zno}$.

Deposition temperature, reaction gas flow rates and dopants and doping levels will be varied to obtain optimum electronic, optical and mechanical properties of the zno layer.

Estimated $R$ \& D costs and times: $\$ 200,000$ over 2 years. 
(5) Shunt-defect reduction/elimination.

Methods available include: thermal and electrical annealing, electrochemical etching/deposition, and clever series/ parallel module design. Shunt analysis using infra-red microscope cameras would help to determine the physical nature of shunt defects, and direct efforts into eliminating the various classes of shunts.

Estimated costs and times: $\$ 200,000$ over 2 years. 
APPENDIX 1.

FABRICATION OF PHOTOVOITAIC NODUIE S TRIES INTERCONNECTS BETIVEN a-SI:H THIN FIIM SOIAR CELIS DEPOSITED ON FLEXIBLE POIYIMIDE SUBSTRATES

D.P. Grimmer,* K.R. Paulson, J.R. Gilbert, and M. Raykowski 3M Company

St. Paul, MN USA

* Present address: Iowa Thin Film Technology, Inc., Ames, IA USA

Abstract: Hyorogenated amorphous silicon device material, deposited on flexible polyimide web substrate by glow-discharge, can be fabricated into photovoltaic modules of series interconnected cells. The roll-to-roll module fabrication process uses automated laser scribing/welding and screen-printing of insulating and conducting inks.

\section{INTRODUCTION}

Photovoltaic modules consist of individual cells connected in series or parallel to provide a desired voltage or current, respectively. Discrete cells consisting of single or polycrystalline wafers are wired in the appropriate series/parallel pattern. Thin film solar cells deposited on an insulating substrate provide a unique opportunity to construct modules of monolithically interconnected cells.

A series interconnect between photovoltaic cells, whether discrete wafers or thin film depositions, consists of an electrical connection between the top contact of one cell to the bottom contact of an adjacent cell. This series electrical connection must not create shunt paths between the top and bottom contacts of either cell. Thus, the module voltage is the sum of the voltages from each cell. To obtain maximum module efficiency, the current output from each cell must be equalized.

A schematic representation of a monoliticic, series interconnect betwe $3 n$ cells in a thin film photovoltaic module is shown in Fig. 1. The current path between the bottom contact of one cell and the top contact of an adjacent cell is indicated by the arrow in Fig. 1. This "idealized" thin film interconnect construction iliustrates the elements of every monolithic interconnect scheme: an electrical open in the top contact and an open in the bottom contact, separated by a low-resistance electrical shunt path conrecting the-'bottom and top contacts of adjacent cells.

\section{DISCUSSION}

The "idealized" monolithic cell interconnect scheme of Fig. 1 
can be fabricated by masking, scribing and/or etching the successive layers of deposited bottom contact, a-Si:H device and top contact. Cleaning of each processed layer is necessary before the next deposition is done. While ultrasonic cleaning in suitable solvents is possible using glass, stainless steel or other rigid substrates, ultrasonic cleaning of layers deposited on polymeric substrates, such as polyimide, resulted in a fracturing of the deposited films and deterioration of device quality. To avoid ultrasonic cleaning, necessary to remove shunt-producing slag created by scribing the metal contact, module construction is not started until after the a-Si:H device layers are deposited.

The optimum method of module fabrication is to begin after the final, top contact is deposited. This method assures maximum cleanliness of the deposited layers and, especially, of the contact interiaces between the layers. However, to avoid creating shunts between top and bottom contacts, the top contact, usually a conducting oxide, must be removed in the vicinity of the interconnect line. Removal of the conducting oxide can be done by $\mathrm{HCl}$ acid etch. Unfortunately, the acid can also arrive at the polyimide/metal contact interface through pin-hole defects and along substrate edges, causing substrate-film delamination in a selfpropagating effect, even after the acid residues are removed by solvent washing and neutralization with a base..

Hence, to avoid immediate and long-term problems, ultrasonic cleaning and acid-etching are techniques not used in thin film module fabrication methods described here. [1], [2], [3] It was felt that wet-cleaning processes are to be avolded in module fabrication from thin film devices on polyimide substrates, Dry cleaning steps, such as plasma etching, can be substituted where necessary to clean contaminated silicon-conducting oxide interfaces.

The module interconnect fabrication method judged to be the most successful, and amenable to roll-to-roll web production, involves fabrication after the a-Si:H layers are deposited, $\because$ but before the top contact is deposited. This preferred interconnect method involves five fabrication steps and is schematically shown in Fig. 2. The current path through the laser-welded interconnect shunt is shown by the arrow in Fig. 2. Note the electrical opens, created by laser scribing in the top and bottom contacts, on either side of the electrical shunt in Fig. 2 .

Starting with web-substrate coated with bottom contact and a-Si:H layers, the construction steps for fabrication are as follows: (1) The a-Si:H/bottom contact layers are laser-scribed down to the polyimide substrate. This creates the individual cell strips by producing the electrical opens in the bottom contact.

(2) Insulating ink lines are screen-printed. Two, parallel ink lines, separated by about an ink-line width, are registered so that one of the insulating lines covers the initial scribe line. These parallel insulating ink lines thus serve two puposes: (a) the first line electrically isolates the exposed bottom contact from the subsequently deposited top contact (preventing shunts); and (b) the second line provides an ablative, beam-stopping surface for subsequent laser-scribing of the electrical open in 
the transparent top contact.

After the top transparent contact is deposited over the partialIy completed module, the series interconnect fabrication process continues:

(3) A conducting ink line is screen-printed over the top contact between the two previously printed insulator ink lines. Depending on the top contact used, it may be necessary to print a wider conducting ink line overlapping the first insulator ink line, to make good contact with the top contact of the adjacent cell. Alternatively, thin conducting grid lines can be printed perpendicular to the main conducting ink lines described above, to make good contact with the adjacent top contact. Because of aesthetic concerns, the grid-line pattern is generally not used. (4) The screen-printed conducting ink line is laser-welded to the bottom contact beneath it. The resulting conducting shunt region is composed of a mixture of metals and metal silicides. The laser wolding step is one that requires careful control. The laser power is adjusted so that the beam just barely avoids cutting through the deposited layers.

(5) Finally, an electrical open in the top contact is laserscribed along the second insulating ink line, which acts as an ablative, beam-stopping region, preventing thermal damage to the layers below.

A variation in this fabrication method is shown schematically in Fig. 3. In this fabrication method, six steps are used. Again, one starts with the bottom contact and a-Si:H layers deposited on the substrate:

(1) A solvent-washable ink strip is printed on the a-Si:H layer. The width of this ink strip is indicated by the gap in the topcontact layer shown in Fig. 3. Inks are used that can be baked up to temperatures that do not damage devices, are low outgassing yet remain removable by solvents.

After the web is coated with the top contact, module fabrication continues:

(2) The web is laser scribed, at high power, through the solvent washable ink, down through the deposited layers to the substrate. This step creates the individual cells.

(3) The web is immersed in a suitable solvent, which dissolves the solvent-washable ink via the laser scribe cut. Hence, the top contact is undercut and removed along with the dissolvable ink. Although this is a wet-cleaning process, the deposited layers and substrate are stable to most solvent washing.

(4) A single insulator ink line is printed over the scribe that goes down to the substrate.

(5) A conducting ink line is printed to bridge over the insulator ink line and make contact with the top contact, as shown. Note the conducting ink does not touch the top contact of the cell to the left.

(6) The conducting ink is laser welded to the bottom contact.

Automated, roll-to-roll laser scribing and screen-printing equipment has been developed for a 4" wide prototype web system, using the module fabrication method described by Fig. 2. The same equipment can be used for the method shown in Fig. 3 , but a 


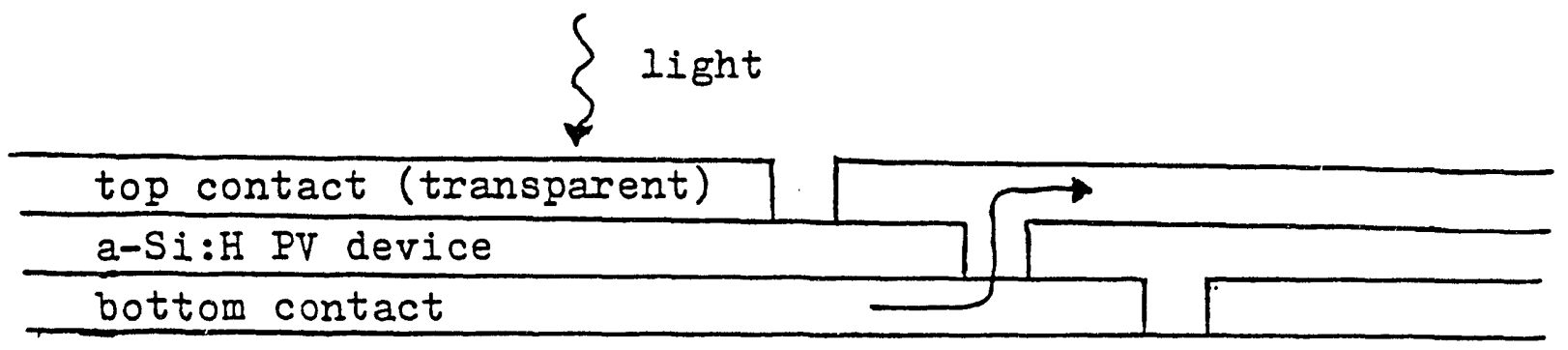

substrate

Figure 1. Cross-section of "idealized" thin-film photovoltaic module interconnect line. Arrow indicates current path.

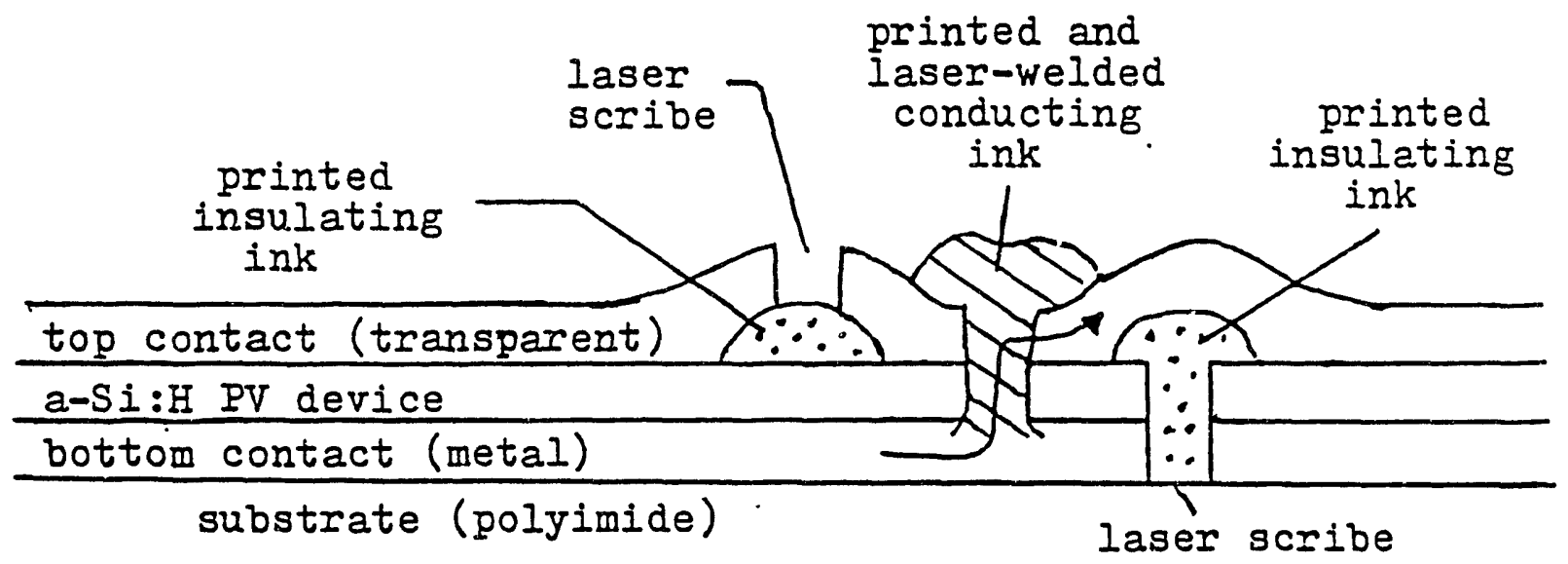

Figure 2. Preferred monolithic series-interconnect construction. Arrow indicates current path.

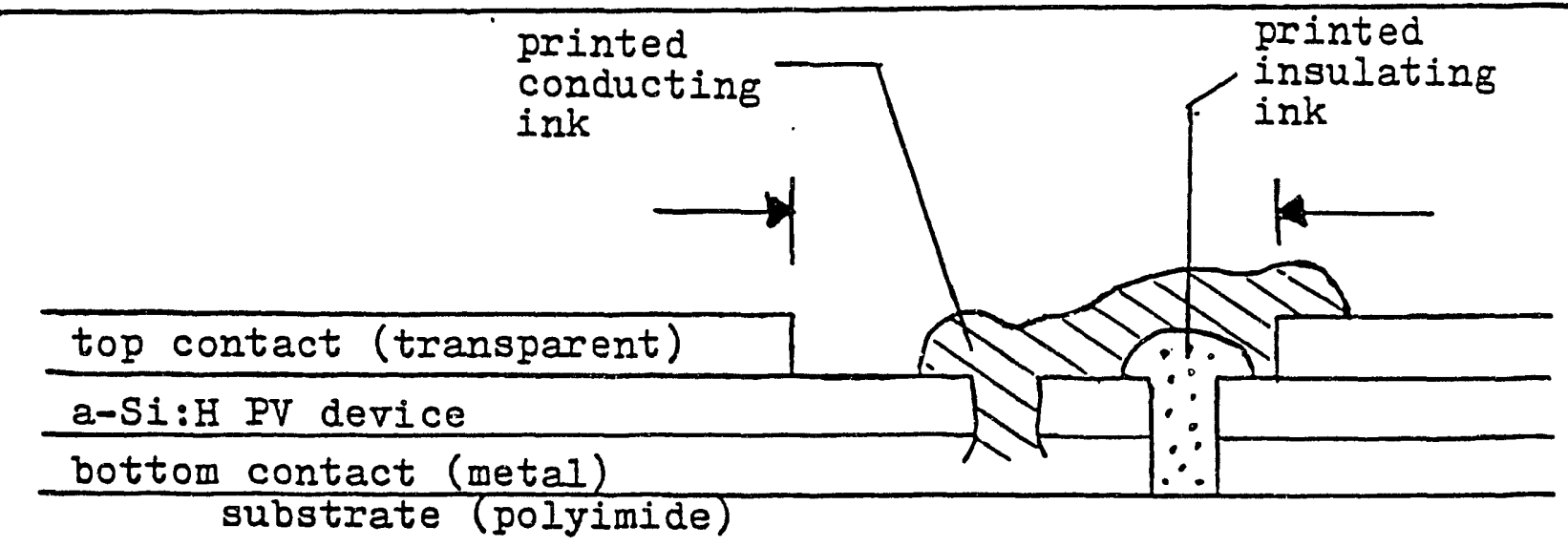

Figure 3. Alternate method of monolithic series-interconnect. construction. The arrows indicate the gap created by printing solvent washable ink on a-Si:H surface. 
solvent-washing system is required also.

The methods described here produce modules with active area efficiencies of $5.6 \%$. Devices produced on polyimide substrates generally have lower yields (more defect shunts) than devices deposited on glass or stainless steel. However, the yields on polyimide are steadily improving, and there is reason to expect that such modules can be produced that equal those obtained on non-polymeric substrates,

Problems peculiar to module fabrication using the methods described here revolve around the choice of insulating and conducting inks. The insulating inks used should be fully curable at $1600 \mathrm{C}$, low-outgassing and cleanable by plasma discharge. The conducting inks should have as high a conductivity as possible, provide stable welds and be unaffected by moisture and other solvents.

\section{CONCLUSION}

Two methods of fabricating photovoltaic module series interconnects between a-Si:H thin film solar cells on polyimide sub- strate have been described. Polymer substrates, such as polyimide, present unique opportunities and difficulties for the fabrication of photovoltaic modules with monolithic series interconnections between cells. The advantages of roll-to-roll production are high volume throughput. The difficulties include ultrasonic cleaning, acid etching, coating adhesion to a polymer substrate, and choice of appropriate inks for electrical isolation and connectivity. However, these are fundamentally engineering problems that are resolvable by an Idisonian. approach. The volume throughput of a roli-to-roll process enables a large number of modules to be statistically analyzed to evaluate parametric changes.

\section{ACKNOWIEDGEMENTS}

The authors would like to thank $W$. Wallace of the Solar Energy Research Institute for his suggestions. The authors would also like to thank F. Jeffrey, * M. Weber, K. Epstein, and N. Tran. for helpful dj.scussions, and $R$. Thompson of Doradus, Inc., for software development in the automated roll-to-roll processes. The support of the U.S. Department of Energy, Solar Energy Research Institute, under subcontract $2 B-4-03056-2$ is also eratefully acknowledged.

\section{REFERENCES}

(1) G.R. Ashton, F.E. Aspen, K.A. Epstein, R.I. Jacobson, F.R. Jeffrey, R.I. Patel, J.R. Schirck, D.J. Mulien (ed.), "Research on High Efficiency Single-Junction Monolithic Thin Film

Amorphous Silicon Solar Cells," Annual Technical Progress Report No. 1, December 1984.

(2) F.E. Aspen, D.P. Grimmer, R.I. Jacobson, F.R. Jeffrey, Fpresent address: Iowa Thin Film Technology, Inc., P.0. Box 1085, Ames, IA 50010 USA. 
N.T. Tran, D.J. Mullen (ed.), "Research on High Efficiency Single-Junction Monolithic Thin Film Amorphous Silicon Solar Cells," Annual rechnical Progress Report No. 2, October 1985. (3) F.E. Aspen, D.P. Grimmer, R.I. Jacobson, F.R. Jeffrey, N.T. Tran, I.C. McGraw (ed.), "Research on High Efficiency Single-Junction Monolithic Thin Film Amorphous Silicon Solar Cells," Final Technical Report, February 1987. 


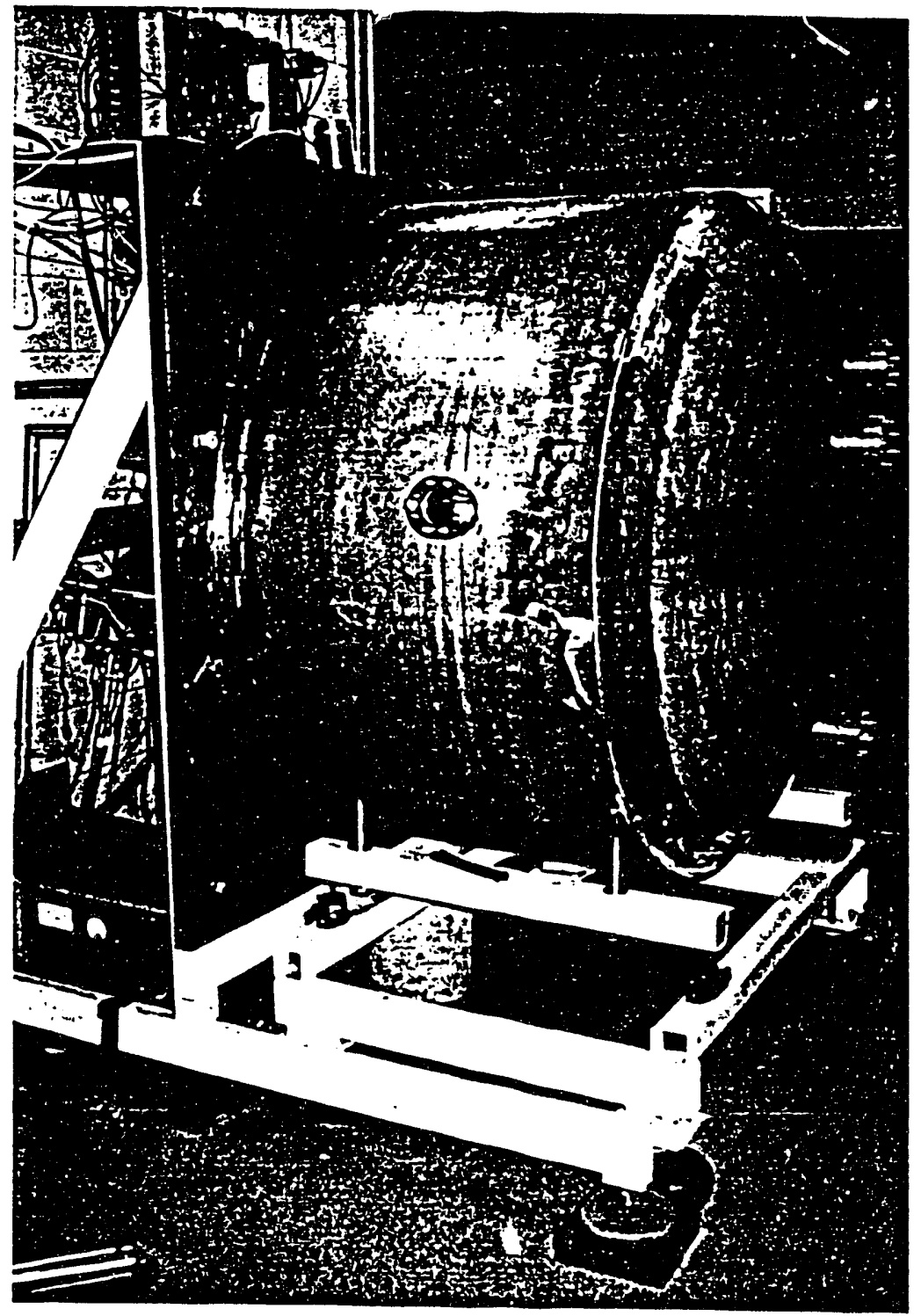

Figure A-2-1

Roll-to-roll metalization deposition sytem. 


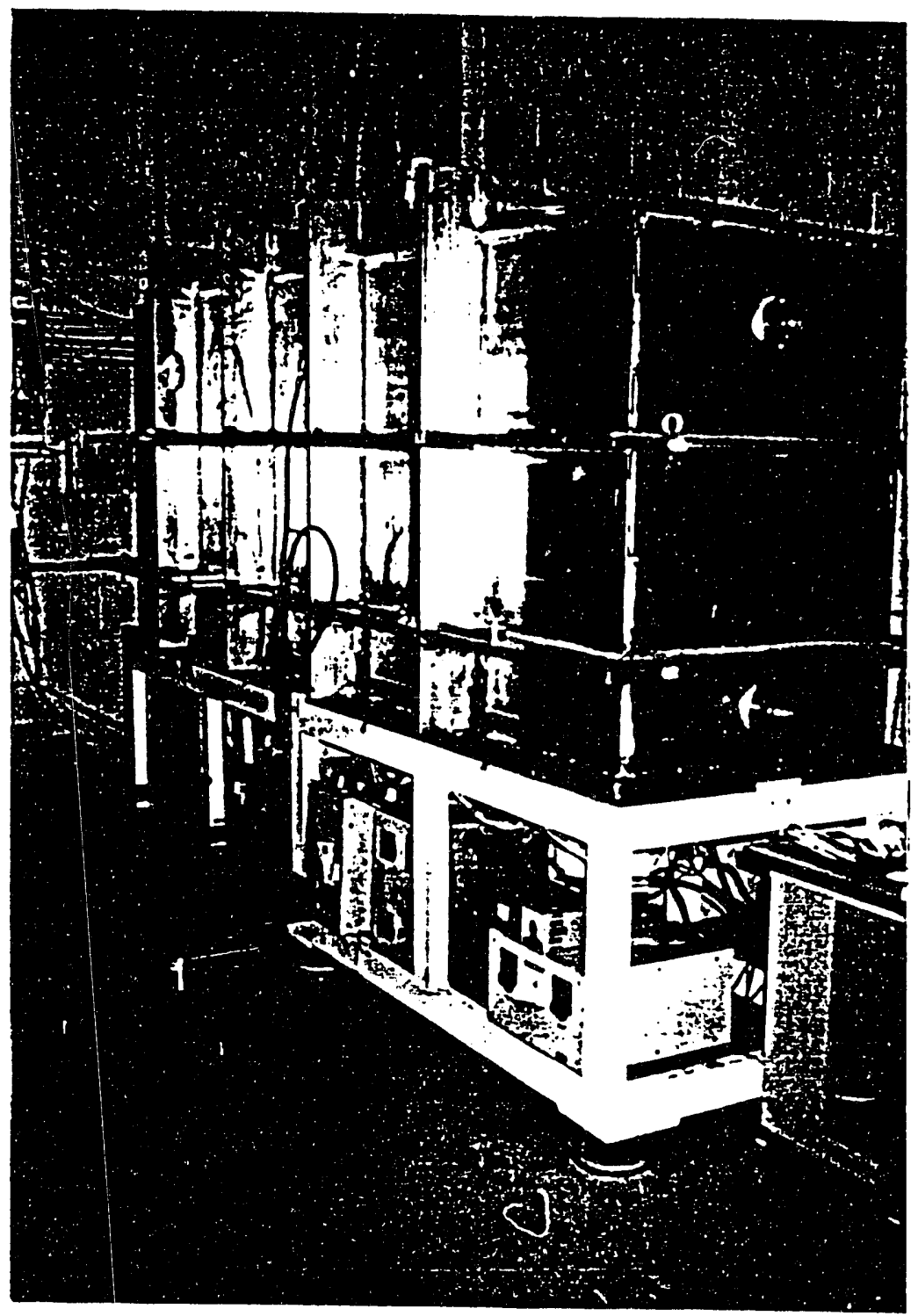

Figure $\mathrm{A}-2-2$

Roll-to-roll a-Si deposition system. 


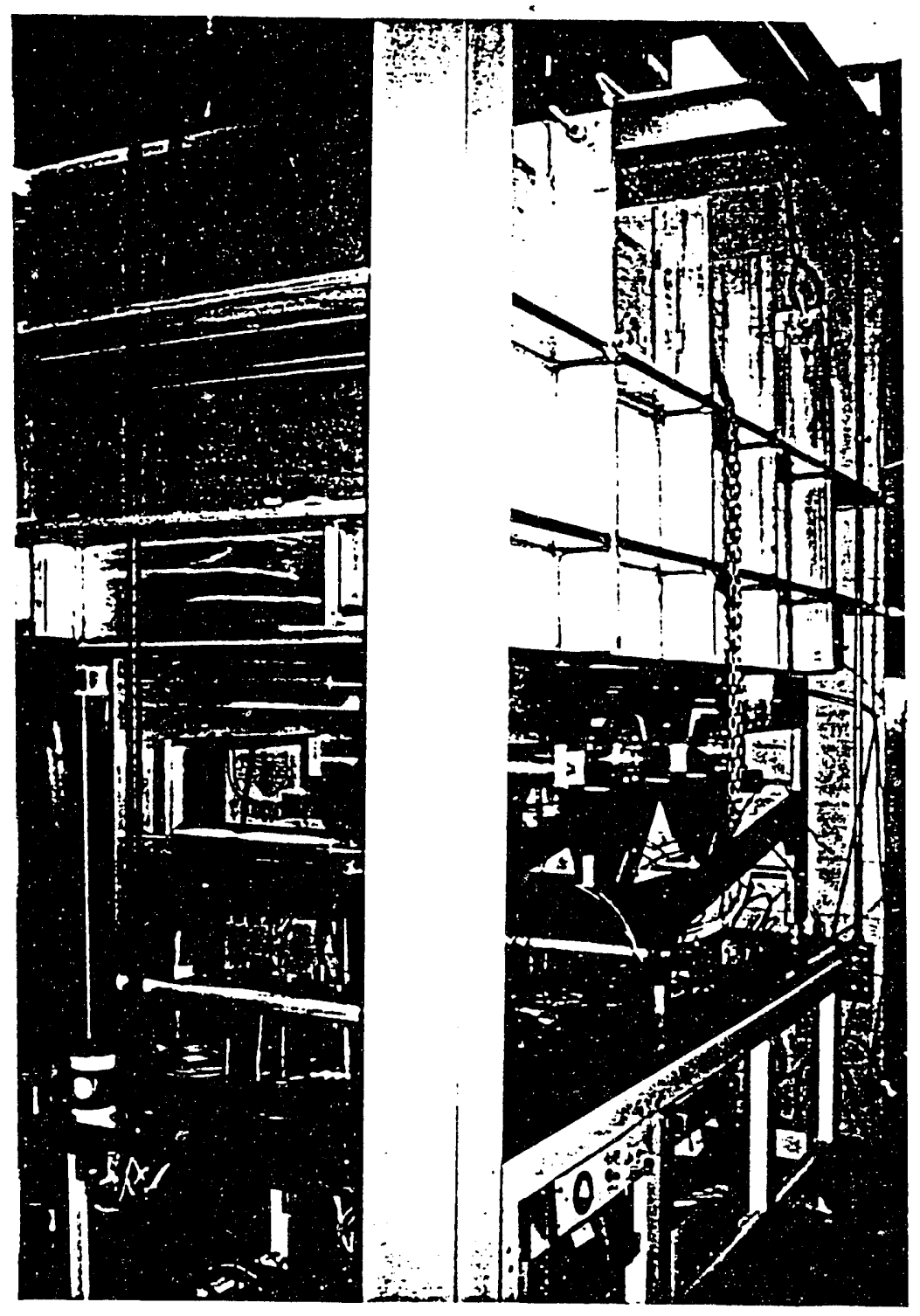

Figure $A-2-3$

Rol1-to-roll Zno deposition system. 


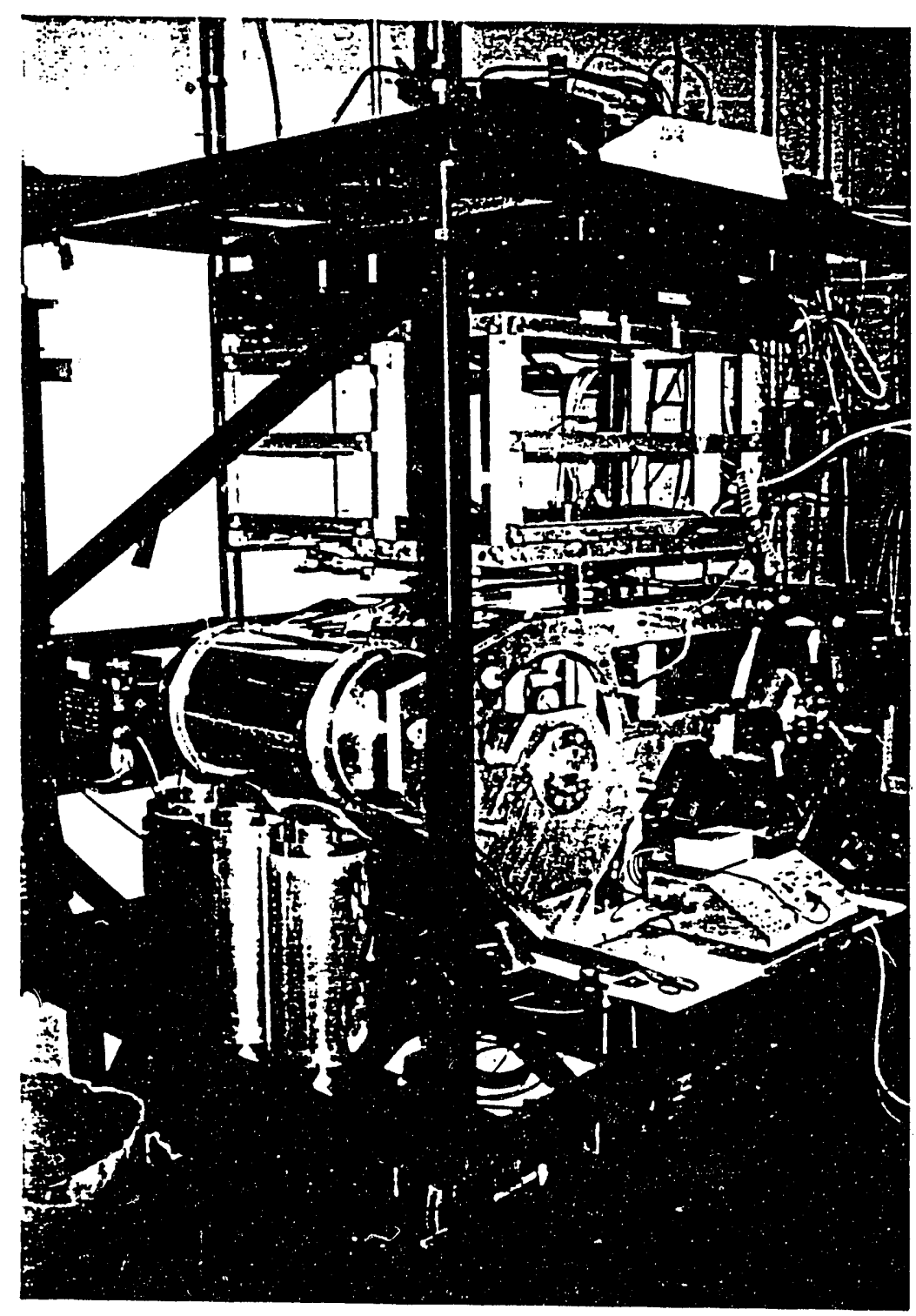

Figure $A-2-4$

Roll-to-roll laser scribing system. 


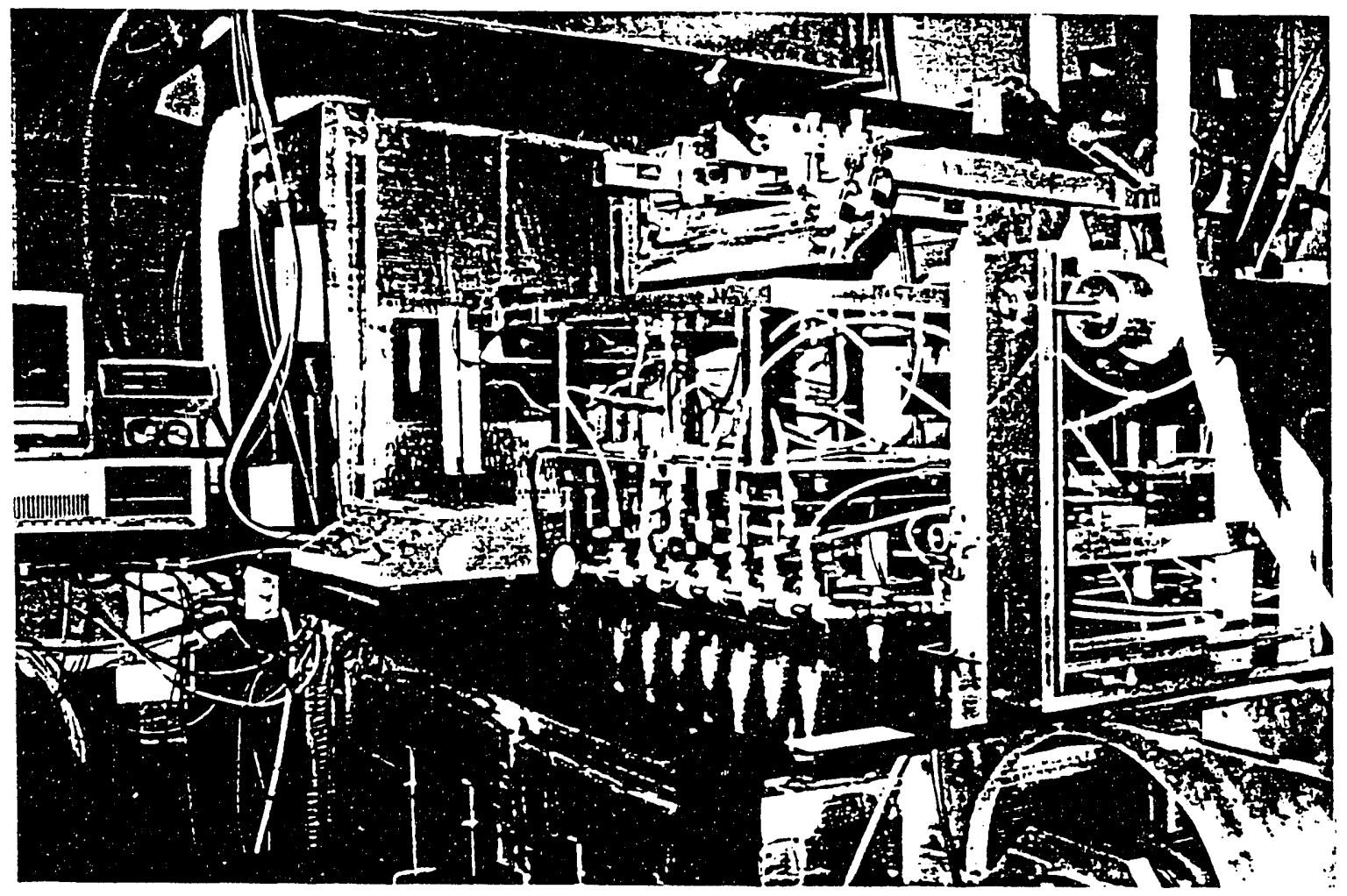

Figure $A-2-5$

Rol1-to-roll screen-printing system. 
APPENDIX 3

Computer Simulation of Various Manufacturing Processes.

Executive Summary:

The operation of the pilot-line has been modelled using a simulation and the performance results input to an economic model allowing the development of a cost per module. The basic pilot line configuration recommended consists of one station of each needed type served by three operators. The cost to produce each module from this basic line is $\$ 5.67$, including materials and outdoor encapsulation, and the annual output is 72 rolls (assuming no station failures and $100 \%$ yield). A lower cost per module is not achievable until the number of each type of deposition station is doubled. Reducing the deposition times will increase output but the impact cannot be assessed until the additional investment required is known. Failure modes will decrease annual production by $15 \%$ to 62 rolls. The configuration using roll-to-roli deposition with sheet-module processing using automatic feed and a print-etch step yielded a cost of $\$ 5.84$ per one ft2 module. Finally, the case of roll-toroll deposition with roll-to-roll module processing and a printetch step yielded a cost of $\$ 5.66$ per one ft2 module.

Assuming a $6 \mathrm{Wp}$ one ft 2 module, the cost per peak watt for the baseline, print-etch/sheet and print-etch/roll-to-roll configurations are $\$ 0.95 / \mathrm{Wp}, \quad \$ 0.97 / \mathrm{Wp}$, and $\$ 0.94 / \mathrm{Wp}$, respectively. 
1.0 Introduction.

1.1 Purpose of the study.

This study provides information on the probable behavior of a prototype manufacturing system. The interaction between components of the system and their interdependencies are investigated. This study considers five issues important to successful operation of the ITFT Pilot Line:

* manufacturing performance

* alternate line configurations

* operating parameters

* manufacturing costs

* alternate investment strategies

* failure modes

Each issue is investigated through the use of a simulation model of the functioning ITFT pilot line. The simulation model's parameters were altered in a systematic way to obtain line performance measures under a variety of operating strategies. The simulation results were statistically analyzed to develop the conclusions presented in this report.

1.2 Tools of the study

Two basic tools were used in the development and analysis of the pilot line simulation model. Those tools are the following software packages: SIMAN and Lotus 1-2-3. Some statistical analysis was carried out with the MINITAB software, although the majority of the work was done using the output processor capabilities of SIMAN.

\subsection{Description of Models used in the study}

The analysis of the pilot line required the develoment of two models. The first, a simulation model, depicts the pilot line as a running system with known operating parameters. The second model is an economic model of the pilot line. The economic model develops the cost per amorphous silicon solar module by combining the costs of materials and production facilities.

\subsection{SIMAN Model of Pilot Line}

2.1.0 Description of the SIMAN Model

The pilot line is modelled as a series of processing stations that act upon rolls of material passing through each station. Processing is interrupted by line or station failures. Depcisition stations are operated up to 24 hours a day in all line configuration scenarios. The operating schedules for other stations vary among line configuration scenarios.

The line is operated as a "push" system with buffer storage 
in front of each station. The priming station is the first visited by each roll. A batch of rolls is periodically processed through the priming station. This batch processing was selected since the primer process is less than $10 \%$ of the time required for the next process, silicon deposition. Batch priming of rolls appears to be the most effective use of the station and does not affect later processing of the rolls (or sheets).

\subsubsection{1.a Modelling Line Operation}

The SIMAN model simulates the movement of rolls or sheets of modules through a series of stations for processing. The processing stations are:

Processing station

Primer

a-si Deposition

Laser Scriber

Screen Printer

Top Contact Deposition

Cutter

Hole Puncher

Busbar

Encapsulation

\section{Operation}

Priming and Metalization of Web. Silicon Deposition.

Scribing Cell patterns in Metal and Top Contact Electrode Layers, and Welding of Conductor Inks.

Print Etching Gels, Insulator Inks and Conducting Inks.

Deposition of Top Contact Layer.

Cut web into sheets for Modules.

Punch Registration Holes in

Substrate for Mechanical

Registration.

Attach Busbars to Modules.

Encapsulate Modules for Outdoor Use.

Not all of these stations are used in each of the three different process scenarios examined here: baseline roll-to-roll (no etching); etching steps plus sheet handling; and etching steps plus roll-to-roll. For example, hole punching is used only for sheet handling. For the processes that are roll-to-roli until module sheets are cut for encapsulation, registration is by optoelectronic methods using registration marks. Encapsulation remains a manual operation.

\subsection{1.b Modeling Operation Times}

The station loading, set-up, processing and unloading times are estimates. Ideally, actual times will be obtained during line operation and substituted in the model.

Exponential and uniform distribution times for loading and unloading of a roll are taken from an exponential distribution with a mean of .25 hours. start-up and set-up times are also taken from exponential distributions.

The loading, unloading, start-up, and set-up operations are all performed manually by operators. Modeling these times by an 
exponential distribution reflects the high nature of variability in manual operations.

Processing times are represented by a uniform distribution. The approximate mean process time for each station was taken as the lower limit of the range of possible times. The upper limit was set as the mean plus $10 \%$.

\subsubsection{Research on Potential Failure Modes}

Equipment failure data was obtained from equipment manufacturers and professionals in industries in which similar equipment is used. Power failure data was obtained from City of Ames data on actual power disturbance data during 1990 . A description of failure modes, mean time to failures, and mean time to repair equipment was obtained.

In every case, conservative estimates on equipment reliability are used. In the future, model failure parameters should be obtained from equipment log data.

\subsubsection{Experimental Method Used in Simulating the Pilot Line}

The model parameters were altered and line operation was simulated for individual runs of nne year during which statistics were collected. The model was run for anywhere from 1000 to 3000 hours without statistics collection in order for the line to achieve a steady state condition.

2.2 Economic Model of Pilot Line

Pilot line performance statistics, averaged from simulation runs, are entered into a Lotus $1-2-3$ spread sheet to develop a cost per module for rolls/sheets produced under any given scenario. Scenario data describing the configuration of the pilot line and its operating parameters must also be entered. The resulting cost per module is a direct manufacturing and material cost.

The inputs required by the spread sheet are as follows:

Inputs to the Economic Model:

* name of scenario

* yield per roll produced

* watt capacity per module

* tax rate

* interest rate (rate of return)

* labor cost per hour

* capital cost and salvage value of each station

* number of stations, hours operating, \# of operators assigned, and power cost per hour

* annual production (\# rolls per year)

* \# of repair/maintenance occurrences per year

* \# of rolls in queue for each station 
The last three items are obtained from simulation results.

2.2.1 Assumptions Used in Economic Model

A cost per module is developed that includes the direct production cost (equipment, labor, power), direct material cost, and work in process costs. Certain assumptions were used in calculating the cost per module. The assumptions are divided into general categories and listed below.

\subsection{1.a Tax Handling Assumptions:}

* equipment is depreciated over 5 years using the ACRS schedule

* salvage value at the end of 5 years is taxed as ordinary income to the manufacturer

* depreciation and operating expenses are used as offsets to the manufacturer's income and provide annual tax credits which are treated as reducing the total cost of production

\subsection{1.b Operating Assumptions:}

* power, maintenance and labor costs are assumed to increase at the rate of $5 \%$ each year

* equipment and operators work the exact number of hours given in the scenario

* mrintenance and repairs are performed by line operators

* operators are trained in all aspects of line operation and can perform all necessary tasks

* no rolls are damaged during failures

\subsubsection{Items NOT INCLUDED in the Economic Model:}

* overhead of the pilot line, including all indirect manufacturing expenses

* cost of stocking spare parts for equipment repair

3.0 Results

\subsection{Manufacturing 'erformance}

This section contains the economic data and simulation data for three basic manufacturing process scenarios:

(1) the basic line using roll-to-roll stations and no wetetching steps ( $i . e$. module manufacture begins before all deposition steps are ended);

(2) the hybrid process using roll-to-roll deposition stations before module manufacture begins, using etching to pattern the top contact layer and sheet module processing;

(3) the roll-to-roll process with depositions completed before 
module manufacture begins, using etching to pattern the top contact layer and roll-to-roll module processing.

Process scenario (1), the basic line, the configuration that the pilot line has presently, has been the most studied. The most notable feature (obtained from graphical analysis) of the pilot line's operation is the cyclical nature of the line's performance. This emphasizes the interdependence of the stations. Early in the study it became obvious that line performance is dominated by the two lengthy deposition processes, the $a-s i$ and top-contact (zno). No gains in output will occur unless these processes can be shortened either by installing additional deposition stations (for each of these two deposition processes) or by speeding up the process. Another interesting note about the basic line, from failure analysis, is that allowing for line failures slows down the average roll processing time so much that fewer operators are actually required on the line.

In the following Results of Economic comparison, the baseline process is scenario 1A. This scenario $1 \mathrm{~A}$ in turn was the optimum scenario of seven baseline variations done in an earlier study by ISU's Dept. of Industrial Engineering. Also in the Results of Economic Comparison summary, the hybrid etching/sheet process with manual sheet or piece feed are listed under Scenarios $2 \mathrm{~B}$ and $2 \mathrm{C}$. The corresponaing etching/sheet processes with automatic sheet or piece feed are listed under Scenarios $4 \mathrm{~A}, 4 \mathrm{~B}$ and $4 \mathrm{C}$. Finally in the Results of Economic Comparison, the etching/roll-to-roll process are listed under Scenarios $3 A$ and $3 B$. 


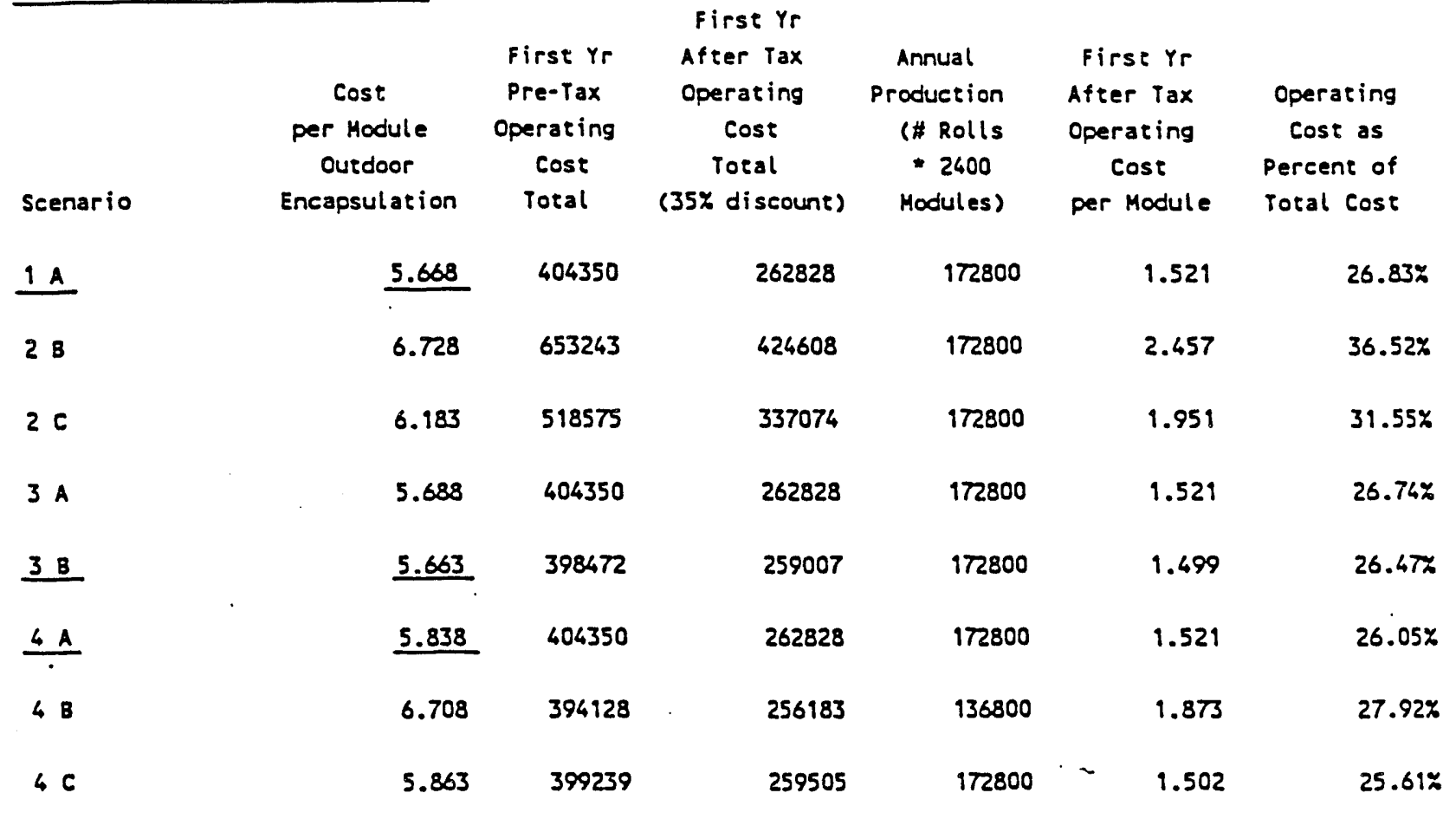

Scenario 1A: Baseline roll-to-roll process with

all equipment running 24 hours a day.

The optimized cost will not differ from scenario 38 util

the additional cost for print etching equipment is included.

Scenario 28: Piece processing with mamul feed at all stations

following the sheet cutting station.

Scenario 2C: Piece processing with manual feed at all stations

following the cutting station. Mon-deposition stations operate

12 hours out off every 24 . Scenario 3A: Roll-to-roll with etch print and with all equipment
running 24 hours per day.
scenario 38: Roll-to-roll with eteh print and with non-
doposition equipment runaing 24 hours 5 days out of 7 days.

Scensrio 4A: Auto feed of non-deposition equipment and all equipment rurning 24 hours per day.

Scenario 48: Auto feed of non-deposition equipment and non-deposition equipment ruming 12 hours of every 24 hours.

Scenario 4C: Auto feed of non-deposition equipment and non-deposition equipment ruming 18 hours of every 24 hours.

Note: In all scenarios 24 hour line supervisor assists with operating tasks and the encapsulation station is run 24 hours per day by a dedicated operator. 
Name of Scenario Being Evaluated: SCENARIO 1 A BASIC LIME

Yield per Roll Produced (\# of modules 2400

Average Watts per Module:

Tax Rate: $\quad 0.35$

Interest Rate: $\quad 0.10$

Labor Rate per/hr for line supervisor $\quad 17.00$

\begin{tabular}{|c|c|c|c|c|c|c|c|}
\hline $\begin{array}{l}\text { Station Input Data } \\
\text { Name }\end{array}$ & Number & $\begin{array}{l}\text { First } \\
\text { Cost }\end{array}$ & $\begin{array}{l}\text { Hon-Depr } \\
\text { First } \\
\text { Cost }\end{array}$ & $\begin{array}{l}\text { Salvage } \\
\text { (as Yrs) }\end{array}$ & $\begin{array}{l}\text { Number } \\
\text { Operators } \\
\text { a station }\end{array}$ & $\begin{array}{l}\text { Effective } \\
\text { Operator } \\
\text { Rate } \\
\text { per } \mathrm{Hr}\end{array}$ & $\begin{array}{l}\text { Cost of } \\
\text { Material/Module } \\
\text { When it reaches } \\
\text { station }\end{array}$ \\
\hline nan & $\cdots \cdots+\cdots$ & $\cdots+\cdots$ & $\ldots+\cdots$ & (n) & n & $\cdots+\cdots$ & $\cdots+\cdots$ \\
\hline Metalization & 1 & 154000 & 120000 & 32500 & 0.000 & 0.00 & 0.80 \\
\hline a-Si Deposition & 1 & 220000 & 120000 & 50000 & 0.167 & 15.00 & 1.00 \\
\hline 2no Deposition & 1 & 81000 & 80000 & 10000 & 0.167 & 15.00 & 1.25 \\
\hline Sheeter & 1 & 20000 & 12500 & 2000 & 0.000 & 9.50 & 1.35 \\
\hline Punch & 0 & 15000 & 12500 & 1500 & 0.000 & 9.50 & 1.35 \\
\hline Laser & 1 & 108000 & 120000 & 25000 & 0.333 & 15.00 & 1.35 \\
\hline Screen Printer & 1 & 46000 & 40000 & 8000 & 0.333 & 15.00 & 1.35 \\
\hline Bus Bar Attachment & 1 & 30000 & 12500 & 10000 & 0.000 & 9.50 & 1.50 \\
\hline Encapsul ator & 2 & 3000 & 12500 & 0 & 1.000 & 9.50 & 1.55 \\
\hline & & & & & & & 1.65 aend \\
\hline
\end{tabular}

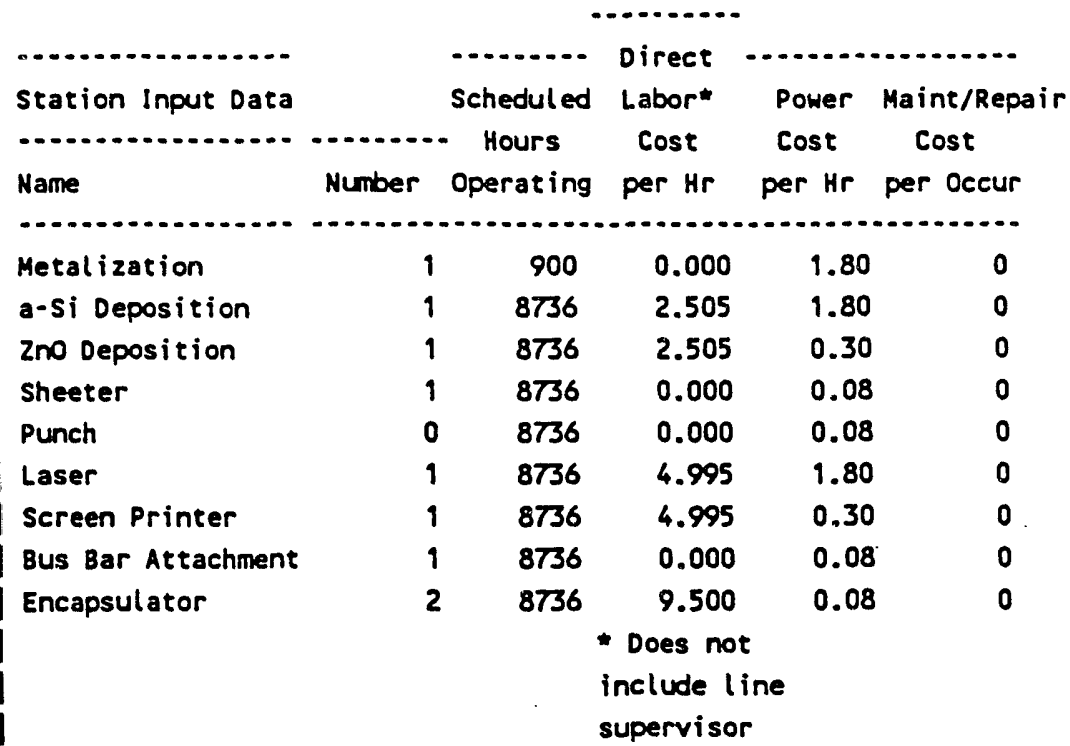




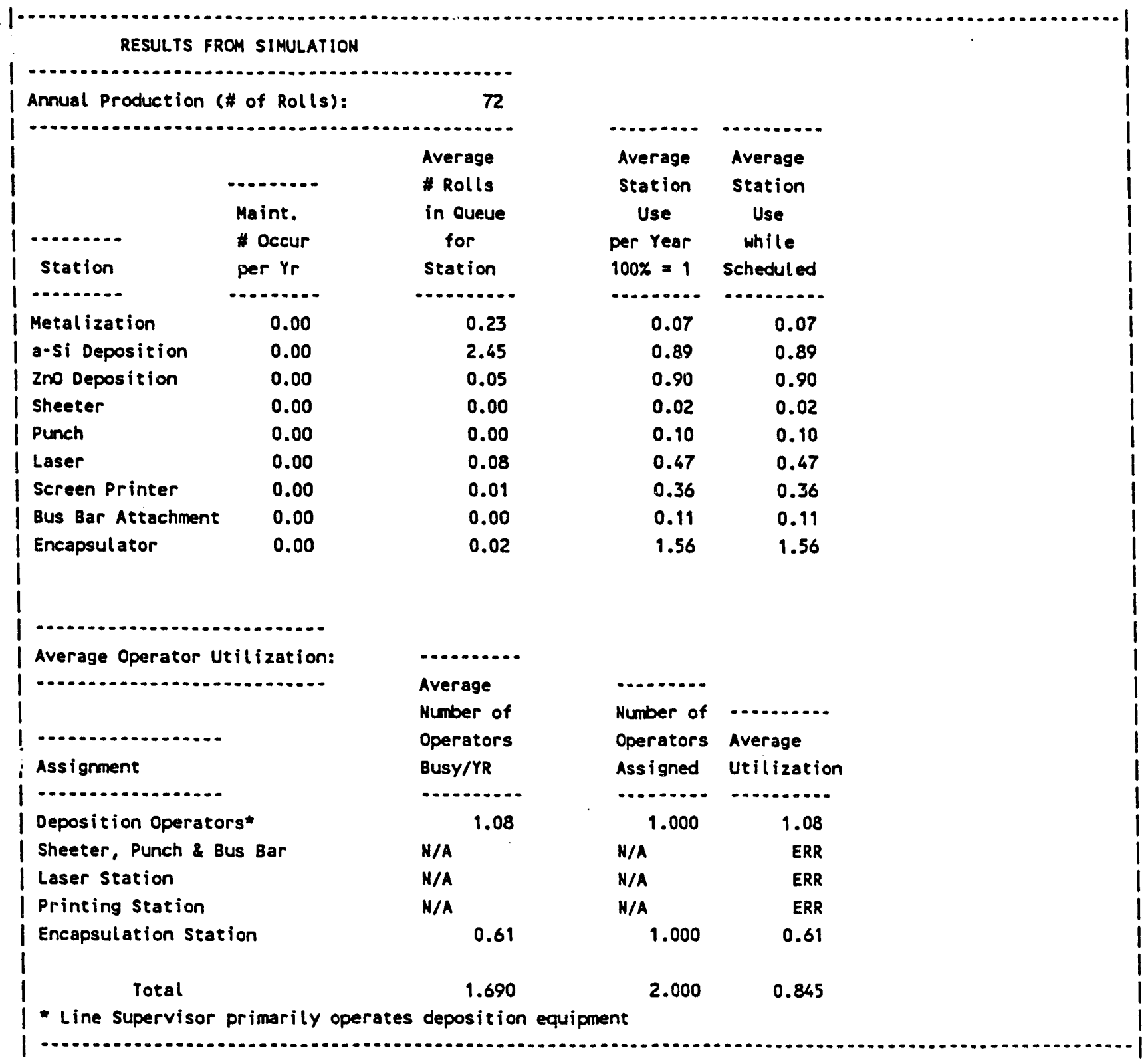


Assumptions:

Tax Rate:

Interest Rate:

0.10

Annual Production (\# rolls):

Yield per Roll Produced (\# of modules) :

Average Watts per Module:

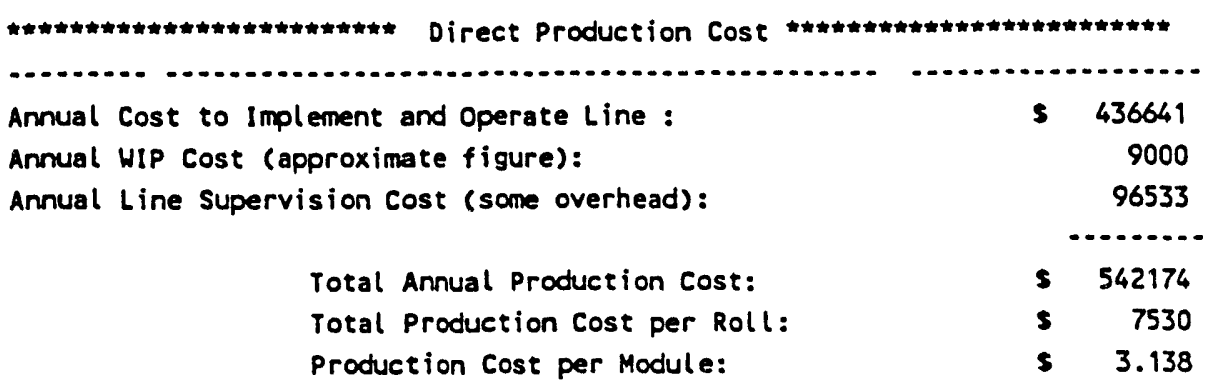

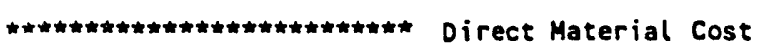

2 Mil Polyimide Substrate

\begin{tabular}{|c|c|}
\hline Material Cost & S/Module \\
\hline$\cdots$ & - \\
\hline no encaps: & 1.550 \\
\hline Material indoor encaps: & 1.650 \\
\hline Material outdoor encaps: & 2.550 \\
\hline
\end{tabular}

NOTE: This calculation assumes $100 \%$ yield per roll. No scrap material charges are included.
1 Mil Polyimide Substrate

\begin{tabular}{|c|c|}
\hline Material Cost per Module & s/Module \\
\hline n. & $\ldots \ldots \ldots$ \\
\hline Material -- no encaps: & 1.150 \\
\hline Material indoor encaps: & 1.250 \\
\hline Material outdoor encaps: & 2.150 \\
\hline
\end{tabular}

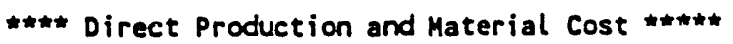

\begin{tabular}{|c|c|c|c|c|}
\hline \multirow{3}{*}{ PROOUCTION \& MATERIAL COSTS } & \multicolumn{2}{|c|}{2 MIL SUBSTRATE } & \multicolumn{2}{|c|}{1 MIL SUBSTRATE } \\
\hline & $\ldots \ldots . . . . . .$. & $\cdots$ & .............. & \\
\hline & S/Moc: le & \$/Watt & s/Module & S/Watt \\
\hline & & $\cdots$ & $\cdots \cdots$ & \\
\hline Production Cost Alone (no material): & 3.138 & 0.628 & 3.138 & 0.628 \\
\hline Cost with NO Encapsulation: & 4.688 & 0.938 & 4.288 & 0.858 \\
\hline Cost with INDOOR Encpsulation: & 4.788 & 0.958 & 4.388 & 0.878 \\
\hline Cost with QUTDOOR Encapsulation: & 5.688 & 1.138 & 5.288 & 1.058 \\
\hline
\end{tabular}




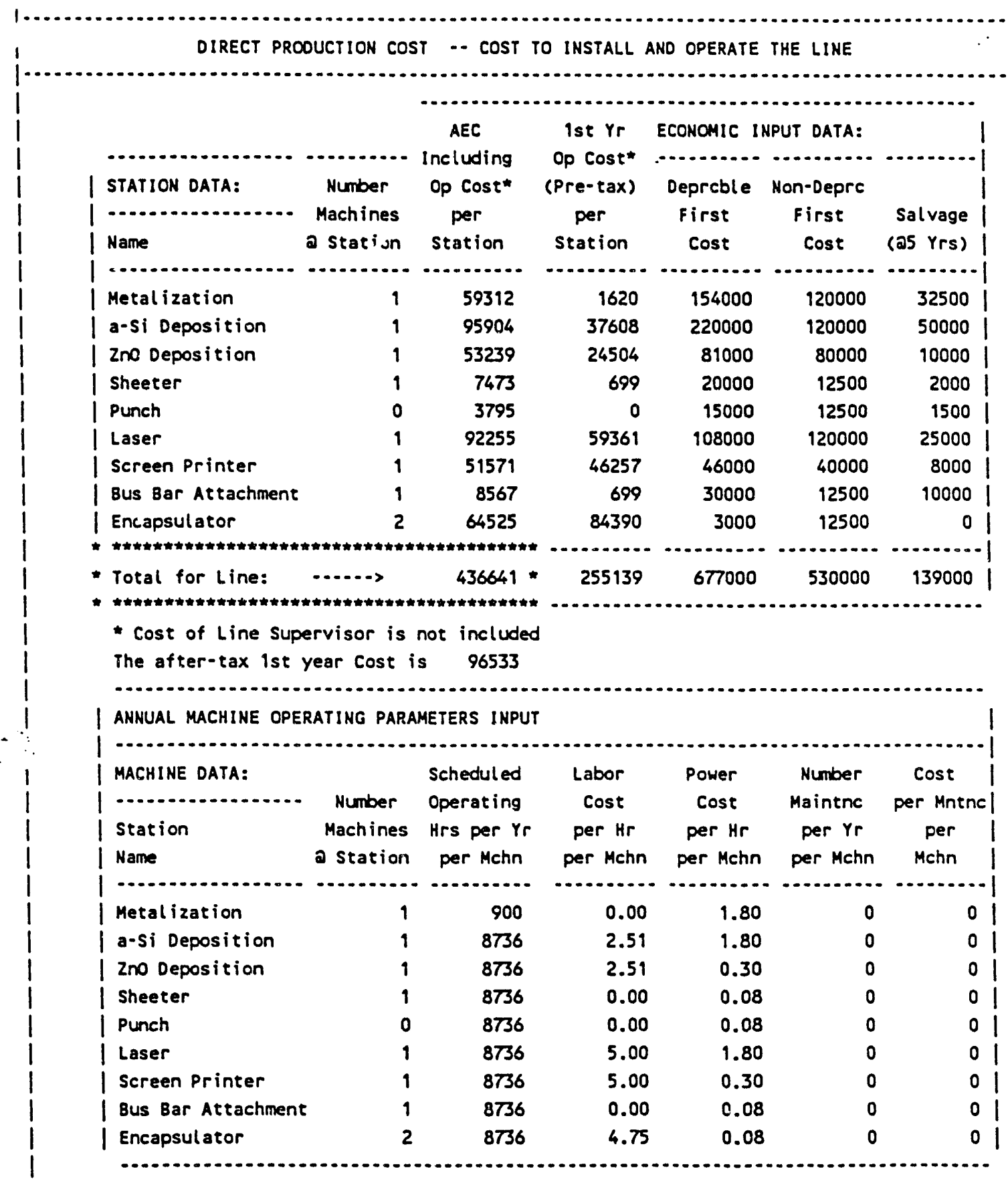

Annual Equivalent Cost for Priming and Metalization Station

$\begin{array}{lr}\text { First Cost: } & 274000 \\ \text { Salvage: } & 32500 \\ \text { Operating Cost: } & 1620\end{array}$




\begin{tabular}{|c|c|c|c|c|c|c|}
\hline \multirow{3}{*}{$\begin{array}{l}\text { End } \\
\text { Year }\end{array}$} & \multicolumn{4}{|c|}{ Annual } & \multicolumn{2}{|c|}{ After-Tax } \\
\hline & First & (ACRS) & Operating & & $\operatorname{Tax}$ & Cash \\
\hline & Cost & Deprec. & Expense & Salvage & Savings & Flow \\
\hline 0 & 274000 & & & & & \\
\hline 1 & & 23100 & 1620 & & 8652 & -7032 \\
\hline 2 & & 33880 & 1701 & $\cdot$ & 12453 & -10752 \\
\hline 3 & & 32340 & 1786 & & 11944 & -10158 \\
\hline 4 & & 32340 & 1875 & & 11975 & -10100 \\
\hline 5 & & 32340 & 1969 & 32500 & 633 & -31164 \\
\hline & & 154000 & & & & \\
\hline
\end{tabular}

Present Value of After-Tax Cash Flow: $\quad-49160$

First Cost of Equipment: $\quad 274000$

Total Present Value of Equipment: $\quad 224840$

Annual Equivalent Cost to Install and Operate (5yr): 59312

Annual Equivalent Cost for a-si Deposition Station

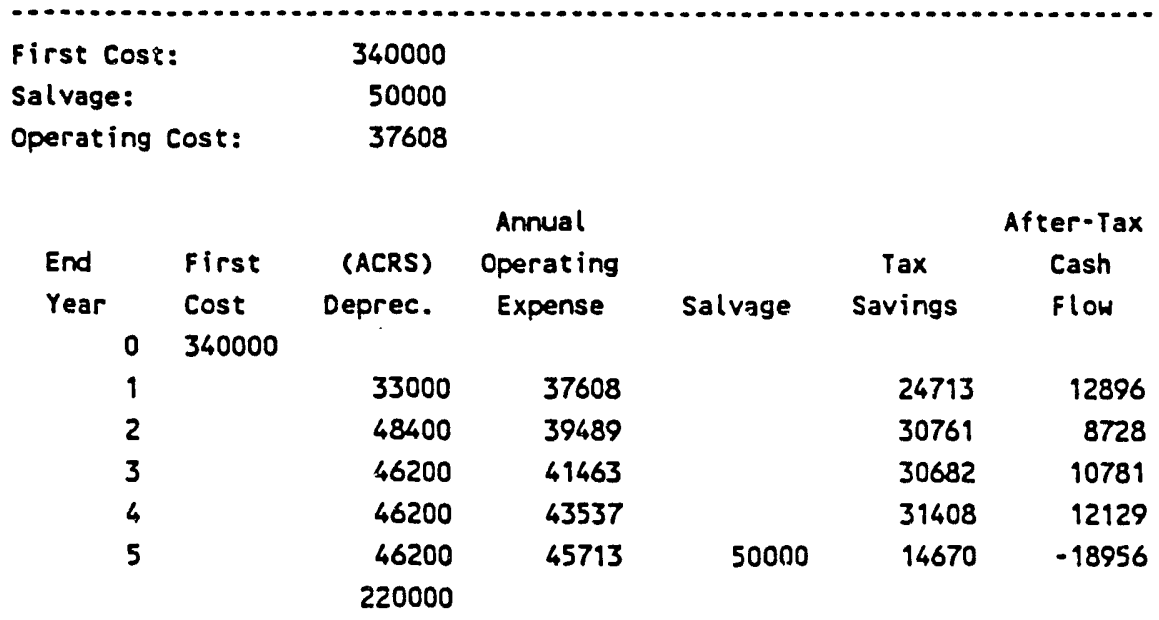

Present Value of After-Tax Cash Flow: 23550

First Cost of Equipment: $\quad 340000$

Total Present Value of Equipment: $\quad 363550$

Annual Equivalent Cost to Install and Operate (5yr): 95904

Annual Equivalent Cost for Zno (top contact coating) Deposition Station

\begin{tabular}{|c|c|c|c|c|c|c|}
\hline \multicolumn{2}{|c|}{ First Cost: } & 161000 & & & & \\
\hline \multicolumn{2}{|l|}{ Salvage: } & 10000 & & & & \\
\hline \multirow[t]{2}{*}{ Operating } & Cost: & 24504 & & & & \\
\hline & & & Annual & & & Ifter-Tax \\
\hline \multirow{3}{*}{$\begin{array}{l}\text { End } \\
\text { Year }\end{array}$} & First & (ACRS) & Operating & & $\operatorname{Tax}$ & Cash \\
\hline & Cost & Deprec. & Expense & Salvage & Savings & Flow \\
\hline & 161000 & & & & & \\
\hline 1 & & 12150 & 24504 & & 12829 & 11675 \\
\hline 2 & & 17820 & 25730 & & 15242 & 10487 \\
\hline
\end{tabular}




$\begin{array}{rrrrrr}3 & 17010 & 27016 & & 15409 & 11607 \\ 4 & 17010 & 28367 & & 15882 & 12485 \\ 5 & 17010 & 29785 & 10000 & 12878 & 6907 \\ & 81000 & & & & \end{array}$

Present Value of After-Tax Cash Flow: - 40818

First Cost of Equipment: $\quad 161000$

Total Present Value of Operating Station: 201818

Annual Equivalent Cost to Install and Operate (5yr): 53239

Annual Equivalent Cost for Sheet Cutting station

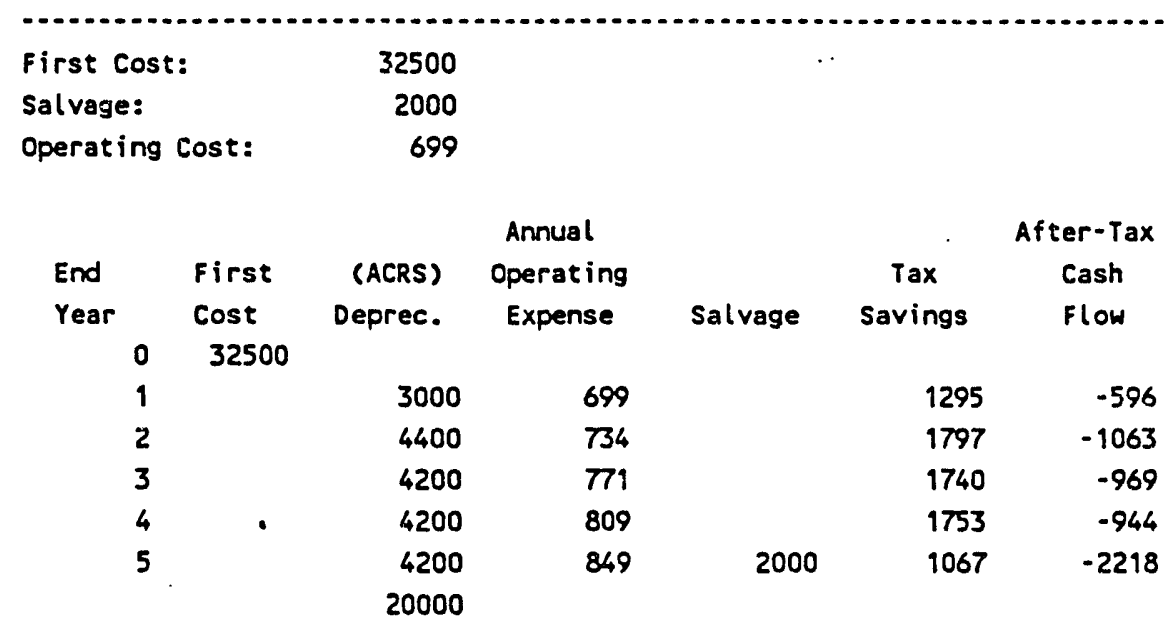

Present Value of After-Tax Cash Flow: $\quad-4170$

First Cost of Equipment: $\quad 32500$

Total Present Value of Operating Station: 28330

Annual Equivalent Cost to Install and Operate (5yr):

Annual Equivalent Cost for Sheet Punching Station

First Cost: $\quad 12500$

Salvage: 0

Operating Cost: $\quad 699$

\begin{tabular}{|c|c|c|c|c|c|c|}
\hline \multirow{3}{*}{$\begin{array}{l}\text { End } \\
\text { Year }\end{array}$} & \multirow[b]{2}{*}{$\begin{array}{l}\text { First } \\
\text { Cost }\end{array}$} & \multicolumn{2}{|r|}{ Annual } & \multicolumn{3}{|c|}{ After-Tax } \\
\hline & & $\begin{array}{l}\text { (ACRS) } \\
\text { Deprec. }\end{array}$ & $\begin{array}{l}\text { Operating } \\
\text { Expense }\end{array}$ & Salvage & $\begin{array}{c}\text { Tax } \\
\text { Savings }\end{array}$ & $\begin{array}{l}\text { Cash } \\
\text { Flow }\end{array}$ \\
\hline & 12500 & & & 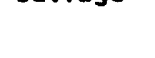 & & \\
\hline 1 & & 0 & 699 & & 245 & 454 \\
\hline 2 & & 0 & 734 & & 257 & 477 \\
\hline 3 & & 0 & 771 & & 270 & 501 \\
\hline 4 & & 0 & 809 & & 283 & 526 \\
\hline 5 & & 0 & 849 & 0 & 297 & 552 \\
\hline & & 0 & & & & \\
\hline
\end{tabular}

Present Value of After-Tax Cash Flow: 
First Cost of Equipment:

Annual Equivalent Cost for Laser Scribing Station

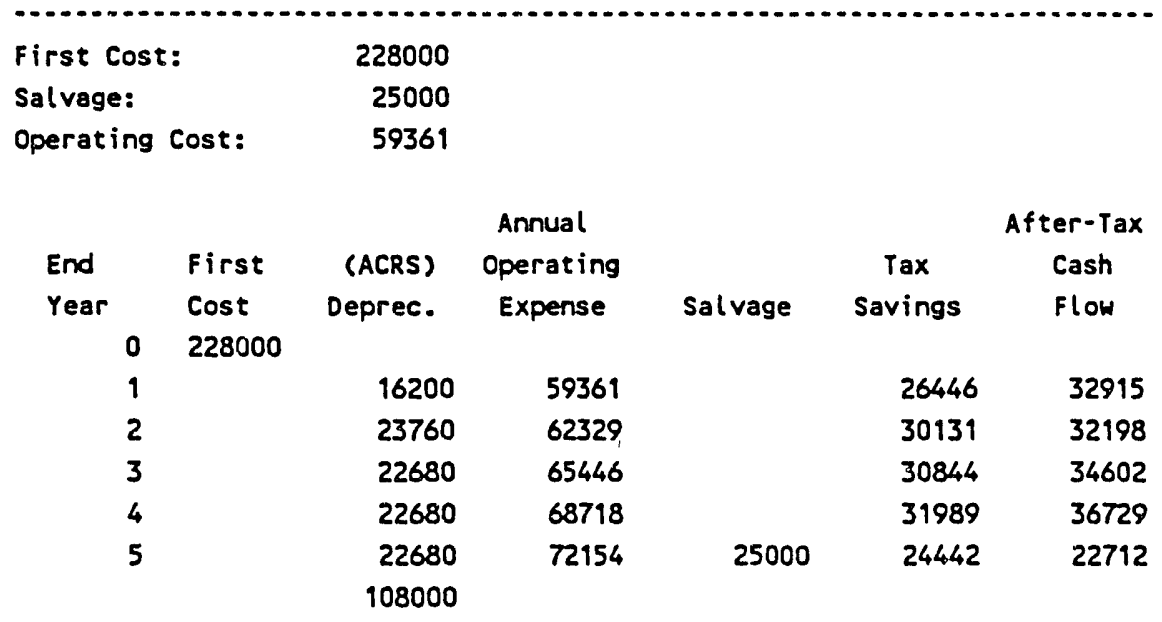

Present Value of After-Tax Cash Flow:

121718

228000

First Cost of Equipment:

349718

Total Present Value of Operating Station:

92255

Annual Equivalent cost to Install and Operate (5yr):

Annual Equivalent Cost for Screen Printing Station

$\begin{array}{lr}\text { First Cost: } & 86000 \\ \text { Salvage: } & 8000 \\ \text { Operating Cost: } & 46257\end{array}$

\begin{tabular}{|c|c|c|c|c|c|c|c|}
\hline \multirow{3}{*}{$\begin{array}{l}\text { End } \\
\text { Year }\end{array}$} & \multicolumn{5}{|c|}{ Annual } & \multicolumn{2}{|c|}{ After-Tax } \\
\hline & & First & (ACRS) & Operating & & $\operatorname{Tax}$ & Cash \\
\hline & 0 & $\begin{array}{l}\text { Cost } \\
86000\end{array}$ & Deprec. & Expense & Salvage & Savings & Flow \\
\hline & 1 & & 6900 & 46257 & & 18605 & 27652 \\
\hline & 2 & & 10120 & 48570 & & 20541 & 28028 \\
\hline & 3 & & 9660 & 50998 & & 21230 & 29768 \\
\hline & 4 & & 9660 & 53548 & & 22123 & 31425 \\
\hline & 5 & & 9660 & 56226 & 8000 & 20260 & 27966 \\
\hline & & & 46000 & & & & \\
\hline
\end{tabular}

Present Value of After-Tax Cash Flow: 109496

First Cost of Equipment: $\quad \mathbf{8 6 0 0 0}$

Total Present Value of Operating Station: 195496

$\begin{array}{ll}\text { Annual Equivalent Cost to Install and Operate (5yr): } & 51571\end{array}$ 
Annual Equivalent Cost for Bus Bar Attachment Station

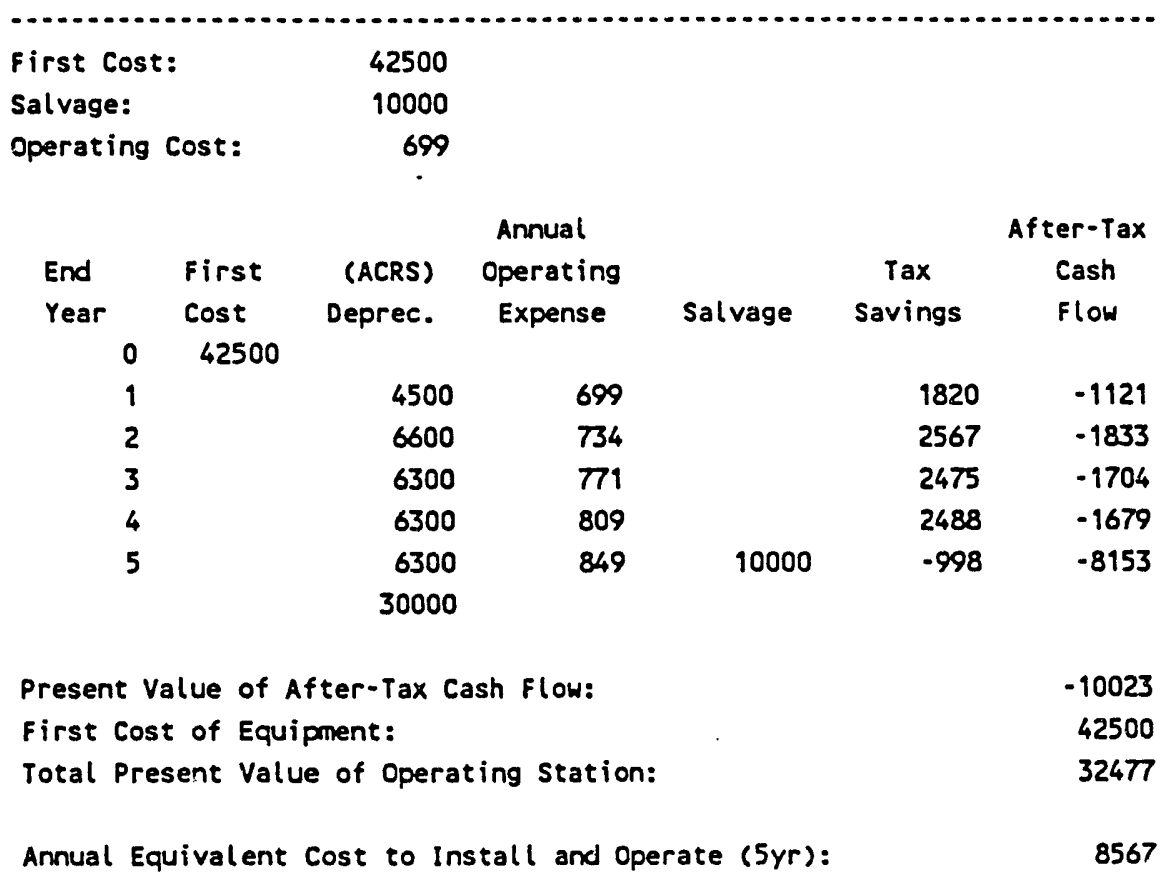

Annual Equivalent Cost for Encapsulation Station

$\begin{array}{lr}\text { First Cost: } & 18500 \\ \text { Salvage: } & 0 \\ \text { Operating Cost: } & 84390\end{array}$

\begin{tabular}{|c|c|c|c|c|c|c|}
\hline \multirow{3}{*}{$\begin{array}{l}\text { End } \\
\text { Year }\end{array}$} & \multicolumn{4}{|c|}{ Annual } & \multicolumn{2}{|c|}{ After-Tax } \\
\hline & First & (ACRS) & Operating & & $\operatorname{Tax}$ & Cash \\
\hline & Cost & Deprec. & Expense & Salvage & Savings & Flow \\
\hline 0 & 18500 & & & & & \\
\hline 1 & & 900 & 84390 & & 29851 & 54538 \\
\hline 2 & & 1320 & 88609 & & 31475 & 57134 \\
\hline 3 & & 1260 & 93040 & & 33005 & 60035 \\
\hline 4 & & 1260 & 97692 & & 34633 & 63059 \\
\hline 5 & & 1260 & 102576 & 0 & 36343 & 66234 \\
\hline & & 6000 & & & & \\
\hline
\end{tabular}

Present Value of After-Tax Cash Flow:

226099

First Cost of Equipment:

18500

Total Present Value of Operating Station:

244599

Annual Equivalent Cost to Install and Operate (5yr):

64525 
SCENARIO $2 \mathrm{~B}$

INPUT DATA REQUIRED FOR ANALYSIS DATE EVALUATED: $3 / 27 / 91$

1

I Name of Scenario Being Evaluated: SCENAR10 2 B Piece Processing

I Yield per Roll Produced (\# of modules 2400

I Average Watts per Module:

| Tax Rate: $\quad 0.35$

Interest Rate: $\quad 0.10$

| Labor Rate per/hr for line supervisor 17.00

Station Input Data

I

I Name

Number

Cost cost (aS Yrs) a station

Operator

Cost of

Material/Module

Metalization

a-si Deposition

$1-154000$

$120000 \quad 32500 \quad 0.000$

Rate

per $\mathrm{Hr}$

Ino Deposition

154000

0.500

0.00

15.00

81000

80000

10000

0.500

15.00

0.333

9.50

12500

2000

15000

12500

1500

0.333

9.50

120000

25000

1.000

9.50

When it reaches

I Laser

46000

40000

8000

1.000

9.50

station

I Bus Bar Attachment

130000

12500

10000

0.333

12500

1.000

9.50

9.50

0.80

1.00

1.25

1.35

1.35

1.35

1.35

1.50

1.55

1.65 Dend

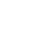
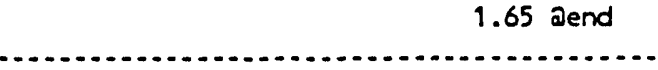

Direct

Power Maint/Repair

Scheduled Labor*

Cost Cost

I

Hours

Cost

Number Operating per $\mathrm{Hr}$ per $\mathrm{Hr}$ per Occur

I Metalization

a-si Deposition

I Zno Deposition

| Sheeter

I Punch

| Laser

I screen Printer

I Bus Bar Attachment

| Encapsulator

$\begin{array}{lr}1 & 900 \\ 1 & 8736 \\ 1 & 8736 \\ 1 & 8736 \\ 1 & 8736 \\ 1 & 8736 \\ 1 & 8736 \\ 1 & 8736 \\ 2 & 8736\end{array}$

0.000

1.80

1.80

7.500

0.30

3.164

0.08

3.164

0.08

9.500

1.80

9.500

0.30

3.164

0.08

9.500

0.08

- Does not

include line

supervisor 


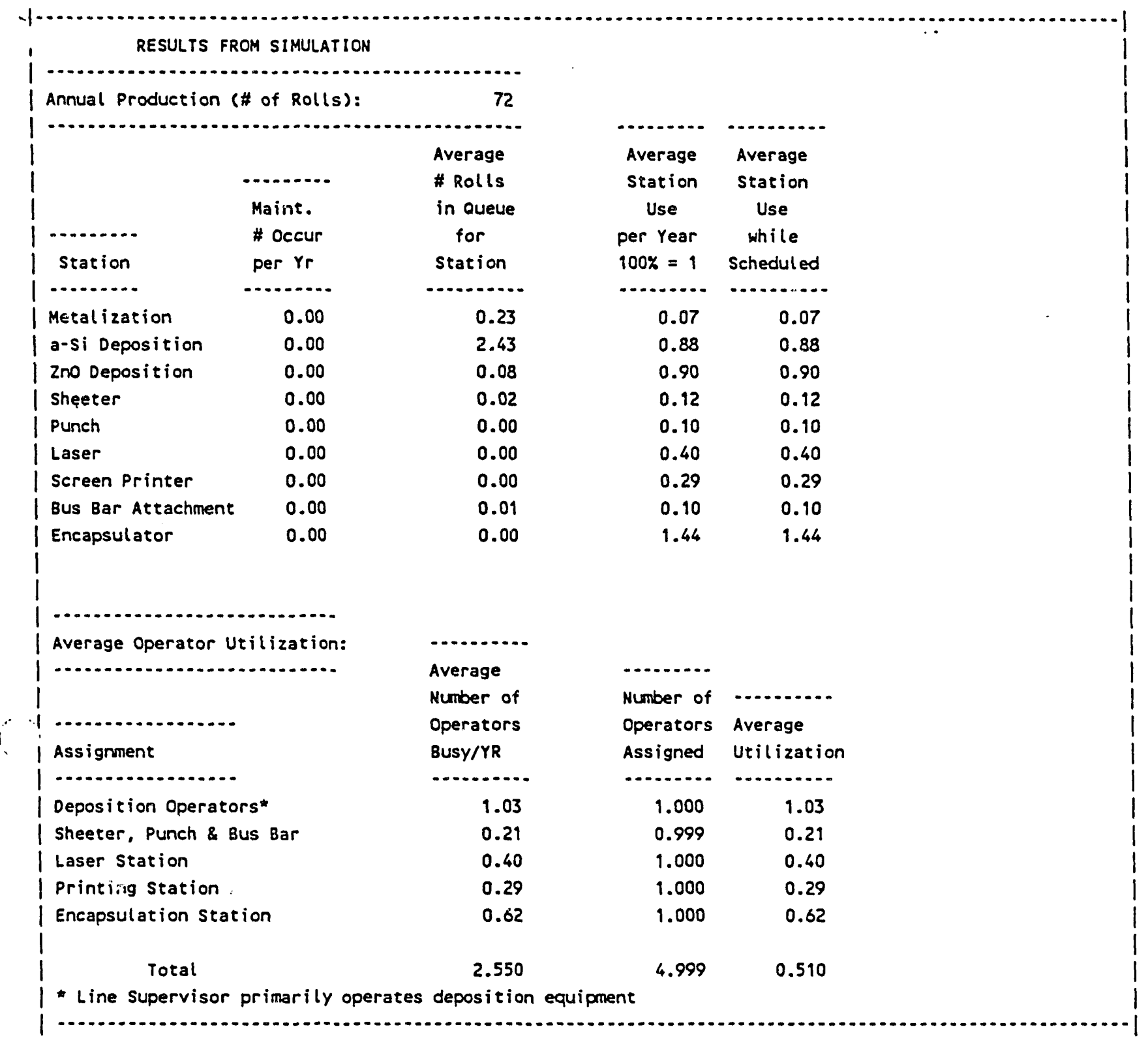




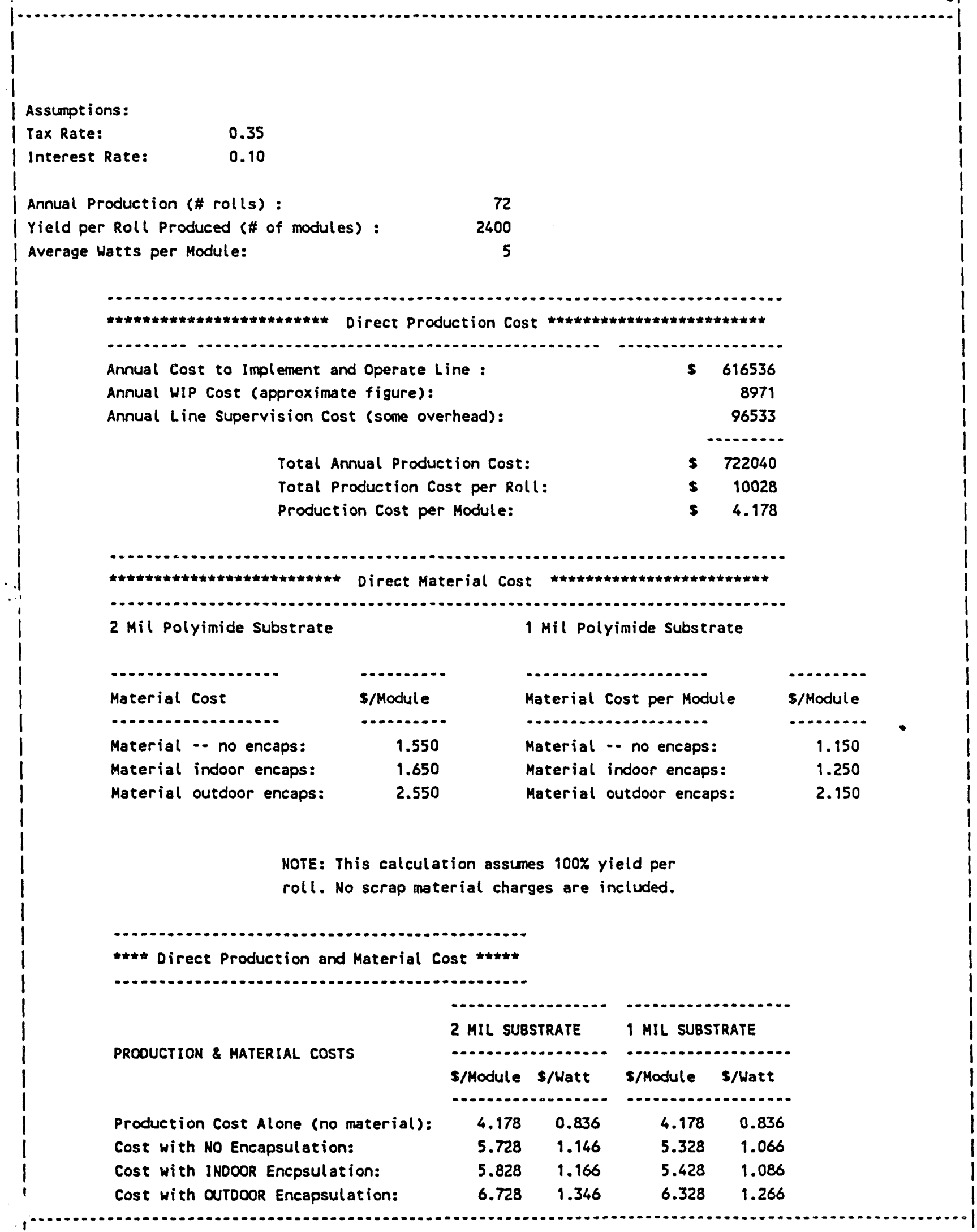




\begin{tabular}{|c|c|c|c|c|c|c|}
\hline \multirow{3}{*}{$\begin{array}{l}\text { End } \\
\text { Year }\end{array}$} & \multicolumn{4}{|c|}{ Annual } & \multicolumn{2}{|c|}{ After-Tax } \\
\hline & First & (ACRS) & Operating & & $\operatorname{Tax}$ & Cash \\
\hline & $\operatorname{Cos} t$ & Deprec. & Expense & Salvage & Savings & Flow \\
\hline 0 & 274000 & & & & & \\
\hline 1 & & 23100 & 1620 & & 8652 & -7032 \\
\hline 2 & & 33880 & 1701 & & 12453 & -10752 \\
\hline 3 & & 32340 & 1786 & & 11944 & -10158 \\
\hline 4 & & 32340 & 1875 & & 11975 & -10100 \\
\hline 5 & & 32340 & 1969 & 32500 & 633 & -31164 \\
\hline & & 154000 & & & & \\
\hline
\end{tabular}

Present Value of After-Tax Cash Flow: $\quad-49160$

First Cost of Equipment: $\quad 274000$

Total Present Value of Equipment: $\quad 224840$

Annual Equivalent Cost to Install and Operate (5yr): 59312

Annual Equivalent Cost for a-Si Deposition Station

\begin{tabular}{|c|c|c|c|c|c|c|}
\hline \multicolumn{2}{|c|}{ First Cost: } & 340000 & & & & \\
\hline \multirow[t]{2}{*}{ Operating } & Cost: & 81245 & & & & \\
\hline & \multicolumn{5}{|c|}{ Annual } & ter-Tax \\
\hline End & First & (ACRS) & Operating & & $\operatorname{Tax}$ & Cash \\
\hline Year & Cost & Deprec. & Expense & Salvage & Savings & Flow \\
\hline 0 & 340000 & & & & & \\
\hline 1 & & 33000 & 81245 & & 39986 & 41259 \\
\hline 2 & & 48400 & 85307 & & 46797 & 38510 \\
\hline 3 & & 46200 & 89572 & & 47520 & 42052 \\
\hline 4 & & 46200 & 94051 & & 49088 & 44963 \\
\hline 5 & & 46200 & 98754 & 50000 & 33234 & 15520 \\
\hline & & 220000 & & & & \\
\hline
\end{tabular}

Present Value of After-Tax Cash Flow: $\quad 141276$

First Cost of Equipment:

340000

Total Present Value of Equipment:

481276

Annual Equivalent Cost to Install and Operate (5yr):

126959

Annual Equivalent Cost for 2 no (top contact coating) Deposition station

\begin{tabular}{|c|c|c|c|c|c|c|}
\hline \multicolumn{2}{|c|}{ First Cost: } & 161000 & & & & \\
\hline \multicolumn{2}{|l|}{ Salvage: } & 10000 & & & & \\
\hline \multirow[t]{2}{*}{ Operating } & Cost: & 68141 & & & & \\
\hline & & & Annusl & & & fter-Tax \\
\hline \multirow{2}{*}{$\begin{array}{l}\text { End } \\
\text { Year }\end{array}$} & First & (ACRS) & Operating & & $\operatorname{Tax}$ & Cash \\
\hline & $\operatorname{Cos} t$ & Deprec. & Expense & Salvage & Savings & Flow \\
\hline 0 & 161000 & & & & & \\
\hline 1 & & 12150 & 68141 & & 28102 & 40039 \\
\hline 2 & & 17820 & 71548 & & 31279 & 40269 \\
\hline
\end{tabular}




$\begin{array}{llllll}3 & 17010 & 75125 & & 32247 & 42878 \\ 4 & 17010 & 78881 & & 33562 & 45319 \\ 5 & 17010 & 82826 & 10000 & 31442 & 41383 \\ & 81000 & & & & \end{array}$

Present Value of After-Tax Cash Flow:

158544

First Cost of Equipment:

161000

Total Present Value of Operating station:

319544

Annual Equivalent Cost to Install and Operate (5yr):

84295

Annual Equivalent cost for sheet Cutting station

$\begin{array}{lr}\text { First Cost: } & 32500 \\ \text { Salvage: } & 2000 \\ \text { Operating Cost: } & 28335\end{array}$

\begin{tabular}{|c|c|c|c|c|c|c|}
\hline \multirow{3}{*}{$\begin{array}{l}\text { End } \\
\text { Year }\end{array}$} & \multirow{3}{*}{$\begin{array}{l}\text { First } \\
\text { Cost }\end{array}$} & \multicolumn{2}{|r|}{ Annual } & \multicolumn{3}{|c|}{ After-Tax } \\
\hline & & (ACRS) & Operating & & $\operatorname{Tax}$ & Cash \\
\hline & & Deprec. & Expense & Salvage & Savings & Flow \\
\hline 0 & 32500 & & & & & \\
\hline 1 & & 3000 & 28335 & & 10967 & 17368 \\
\hline 2 & & 4400 & 29752 & & 11953 & 17799 \\
\hline 3 & & 4200 & 31240 & & 12404 & 18836 \\
\hline 4 & & 4200 & 32802 & & 12951 & 19851 \\
\hline 5 & & 4200 & 34442 & 2000 & 12825 & 19617 \\
\hline & & 20000 & & & & \\
\hline
\end{tabular}

Present Value of After-Tax Cash Flow:

70389

First Cost of Equipment:

32500

Total Present Value of Operating Station:

102889

Annual Equivalent Cost to Install and Operate (5yr): 27142

Annual Equivalent Cost for Sheet Punching Station

$\begin{array}{lr}\text { First Cost: } & 27500 \\ \text { Salvage: } & 1500 \\ \text { Operating Cost: } & 28335\end{array}$

\begin{tabular}{|c|c|c|c|c|c|c|}
\hline \multirow{3}{*}{$\begin{array}{l}\text { End } \\
\text { Year }\end{array}$} & \multicolumn{4}{|c|}{ Annual } & \multicolumn{2}{|c|}{ After-Tax } \\
\hline & First & (ACRS) & Operating & & Tax & Cash \\
\hline & Cost & Deprec. & Expense & Salvage & Savings & Flon \\
\hline 0 & 27500 & & & & & \\
\hline 1 & & 2250 & 28335 & & 10705 & 17630 \\
\hline 2 & & 3300 & 29752 & & 11568 & 18184 \\
\hline 3 & & 3150 & 31240 & & 12036 & 19203 \\
\hline 4 & & 3150 & 32802 & & 12583 & 20219 \\
\hline 5 & & 3150 & 34442 & 1500 & 12632 & 20310 \\
\hline & & 15000 & & & & \\
\hline
\end{tabular}


First Cost of Equipment:

Annual Equivalent Cost for Laser Scribing Station

$\begin{array}{lr}\text { First Cost: } & 228000 \\ \text { Salvage: } & 25000 \\ \text { Operating Cost: } & 98717\end{array}$

\begin{tabular}{|c|c|c|c|c|c|c|}
\hline \multirow{3}{*}{$\begin{array}{l}\text { End } \\
\text { Year }\end{array}$} & \multicolumn{4}{|c|}{ Annual } & \multicolumn{2}{|c|}{ After-Tax } \\
\hline & First & (ACRS) & Operating & & $\operatorname{Tax}$ & Cash \\
\hline & $\cos t$ & Deprec. & Expense & Saivage & Savings & Flor \\
\hline 0 & 228000 & • & & & & \\
\hline 1 & & 16200 & 98717 & & 40221 & 58496 \\
\hline 2 & & 23760 & 103653 & & 44594 & 59058 \\
\hline 3 & & 22680 & 108835 & & 46030 & 62805 \\
\hline 4 & & 22680 & 114277 & & 47935 & 66342 \\
\hline 5 & & 22680 & 119991 & 25000 & 41185 & 53806 \\
\hline & & 108000 & & & & \\
\hline
\end{tabular}

Present Value of After-Tax Cash Flow: 227895

First Cost of Equipment: $\quad 228000$

Total Present Value of Operating Station: 455895

Annual Equivalent Cost to Install and Operate (5yr): 120264

Annual Equivalent Cost for Screen Printing Station

$\begin{array}{lr}\text { First Cost: } & 86000 \\ \text { Salvage: } & 8000\end{array}$

Operating Cost: 85613

\begin{tabular}{|c|c|c|c|c|c|c|}
\hline \multirow{3}{*}{$\begin{array}{l}\text { End } \\
\text { Year }\end{array}$} & \multicolumn{4}{|c|}{ Annual } & \multicolumn{2}{|c|}{ After-Tax } \\
\hline & First & (ACRS) & Operating & & $\operatorname{Tax}$ & Cash \\
\hline & Cost & Deprec. & Expense & Salvage & Savings & Flow \\
\hline 0 & 86000 & & & & & \\
\hline 1 & & 6900 & 85613 & & 32379 & 53233 \\
\hline 2 & & 10120 & 89893 & & 35005 & 54889 \\
\hline 3 & & 9660 & 94388 & & 36417 & 57971 \\
\hline 4 & & 9660 & 99108 & & 38069 & 61039 \\
\hline 5 & & 9660 & 104063 & 8000 & 37003 & 59060 \\
\hline & & 46000 & & & & \\
\hline
\end{tabular}

Present Value of After-Tax Cash Flow: 215673

First Cost of Equipment: $\quad 86000$

$\begin{array}{ll}\text { Total Present Value of Operating Station: } 301673 & 3600\end{array}$

Annual Equivalent Cost to Install and Operate (5yr): 79581 
Annual Equivalent Cost for Bus Bar Attachment Station

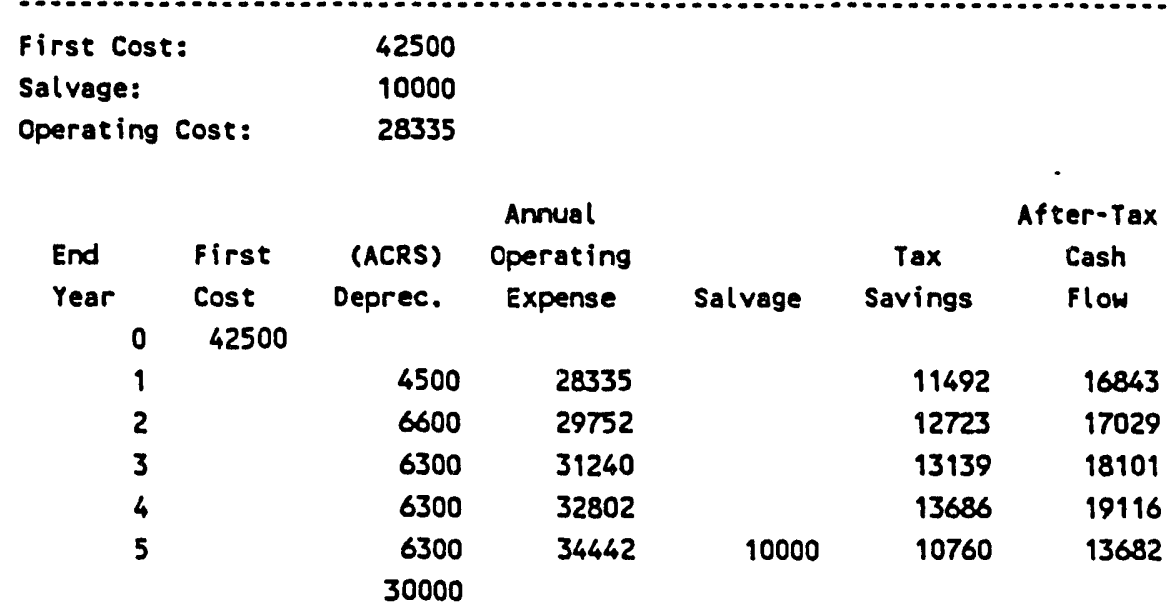

Present Value of After-Tax Cash Flow:

rotal Present Value of Operating Station:

107036

Annual Equivalent Cost to Install and Operate (5yr):

28236

Annual Equivalent cost for Encapsulation station

\begin{tabular}{|c|c|c|c|c|c|c|}
\hline \multicolumn{2}{|c|}{ First Cost: } & 18500 & & & & \\
\hline \multicolumn{2}{|c|}{ Salvage: } & 0 & & & & \\
\hline \multirow[t]{2}{*}{ Operating } & Cost: & 84390 & & & & \\
\hline & \multicolumn{5}{|c|}{ Annual } & fter-Tax \\
\hline End & First & (ACRS) & Operating & & $\operatorname{Tax}$ & Cash \\
\hline Year & Cost & Deprec. & Expense & Salyage & Savings & Flow \\
\hline 0 & 18500 & & & & & \\
\hline 1 & & 900 & 84390 & & 29851 & 54538 \\
\hline 2 & & 1320 & 88609 & & 31475 & 57134 \\
\hline 3 & & 1260 & 93040 & & 33005 & 60035 \\
\hline 4 & & 1260 & 97692 & & 34633 & 63059 \\
\hline 5 & & 1260 & 102576 & 0 & 36343 & 66234 \\
\hline & & 6000 & & & & \\
\hline
\end{tabular}

Present Value of After-Tax Cash Flou:

226099

First Cost of Equipment:

18500

Total Present Value of Operating Station:

244599

Anmual Equivalent Cost to Install and Operate (5yr):

64525 


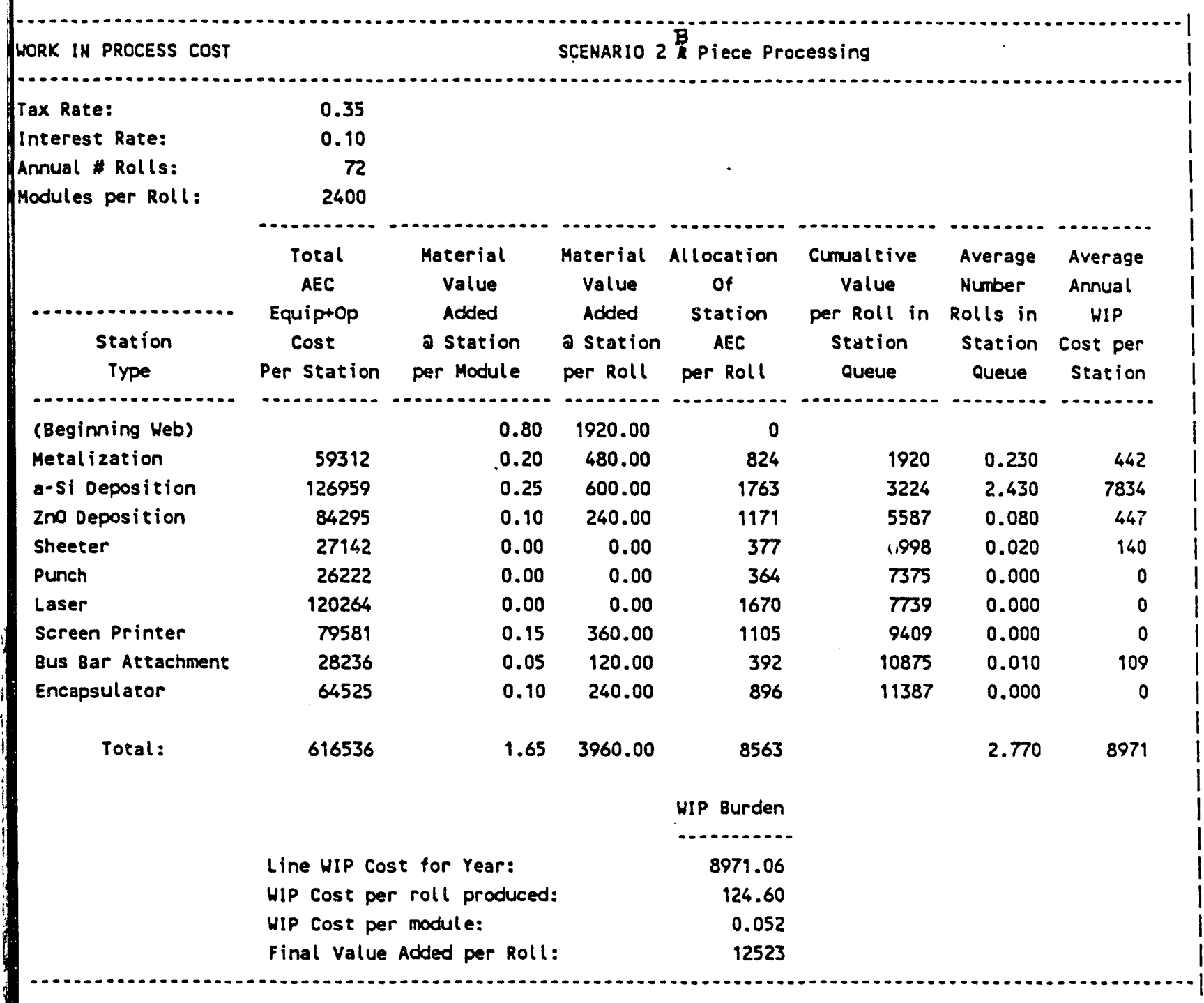




\section{SCENARIO $2 \mathrm{C}$}

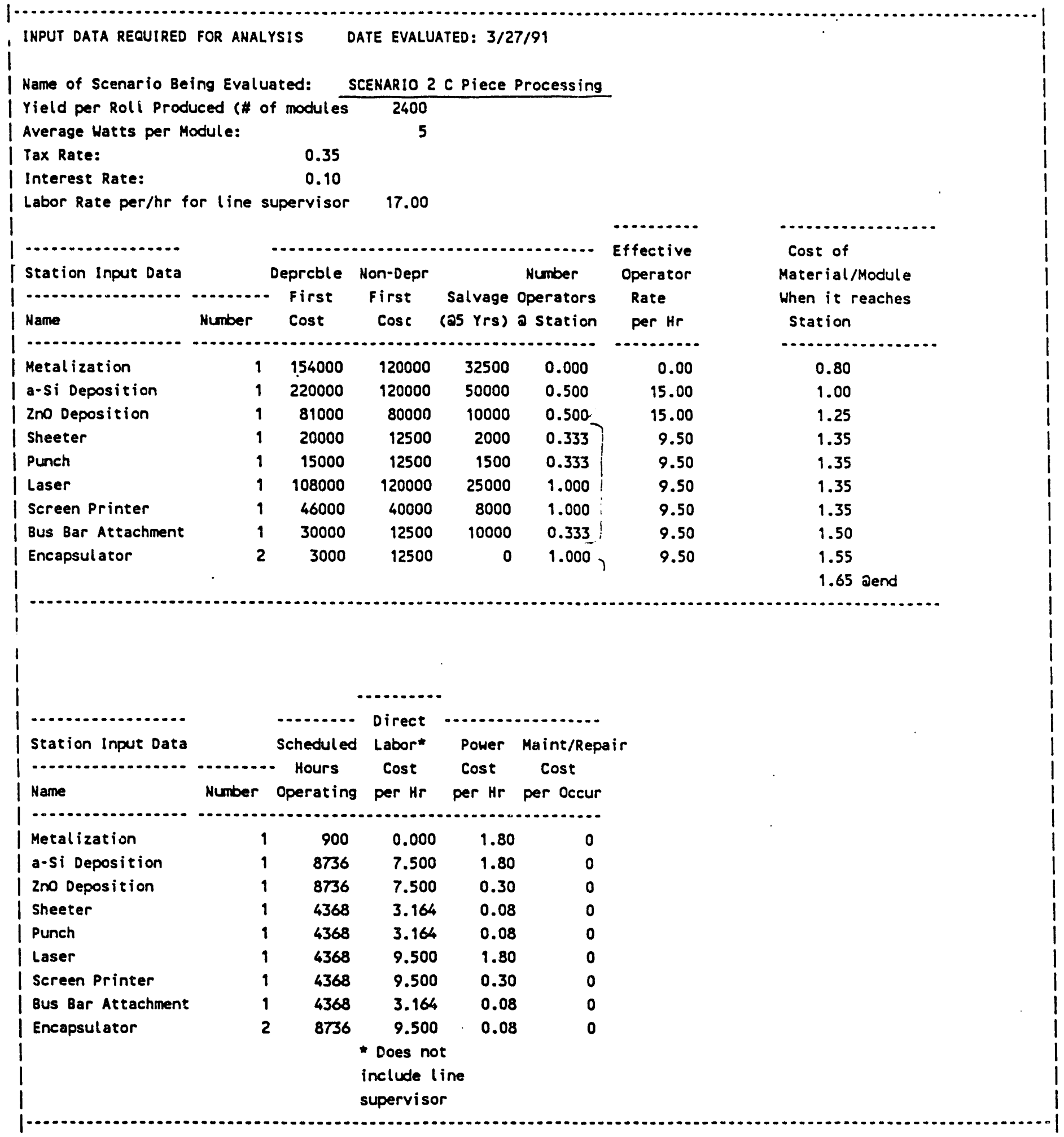


Assumptions:

Tax Rate:

0.35

Interest Rate:

0.10

Annual Production (\# rolls):

Yield per Roll Produced (\# of modules):

Average Watts per Module:

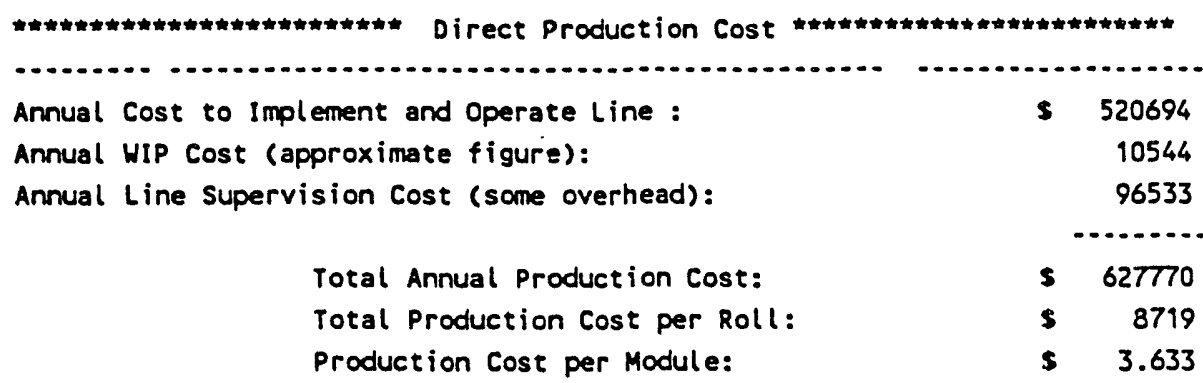

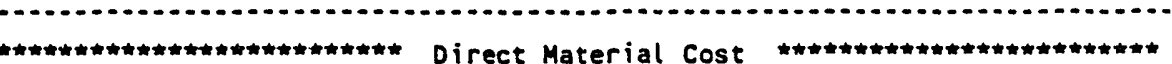

2 Mil Polyimide Substrate

\begin{tabular}{lc} 
Material Cost & \$/Module \\
\hline Material ... no encaps: & 1.550 \\
Material indoor encaps: & 1.650 \\
Material outdoor encaps: & 2.550
\end{tabular}

1 Mil Polyimide Substrate

\begin{tabular}{|c|c|}
\hline Material Cost per Module & S/Module \\
\hline (1) & $\cdots \ldots$ \\
\hline Material -- no encaps: & 1.150 \\
\hline Material indoor encaps: & 1.250 \\
\hline Material outdoor encaps: & 2.150 \\
\hline
\end{tabular}

NOTE: This calculation assumes $100 \%$ yield per roll. No scrap material charges are included.

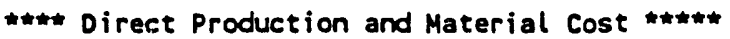

\begin{tabular}{|c|c|c|c|c|}
\hline \multirow{3}{*}{ PROOUCTION \& MATERIAL COSTS } & \multicolumn{2}{|c|}{2 MIL SUBSTRATE } & 1 MIL SUBS & - \\
\hline & (n)........... & - n-n & (n) & $\cdots$ \\
\hline & movare & Hate & movire & thes \\
\hline Production Cost Alone (no material): & 3.633 & 0.727 & 3.633 & 0.727 \\
\hline Cost with NO Encapsulation: & 5.183 & 1.037 & 4.783 & 0.957 \\
\hline Cost with INDOOR Encpsulation: & 5.283 & 1.057 & 4.883 & 0.977 \\
\hline Cost with QUTDOOR Encapsulation: & 6.183 & 1.237 & 5.783 & 1.157 \\
\hline
\end{tabular}




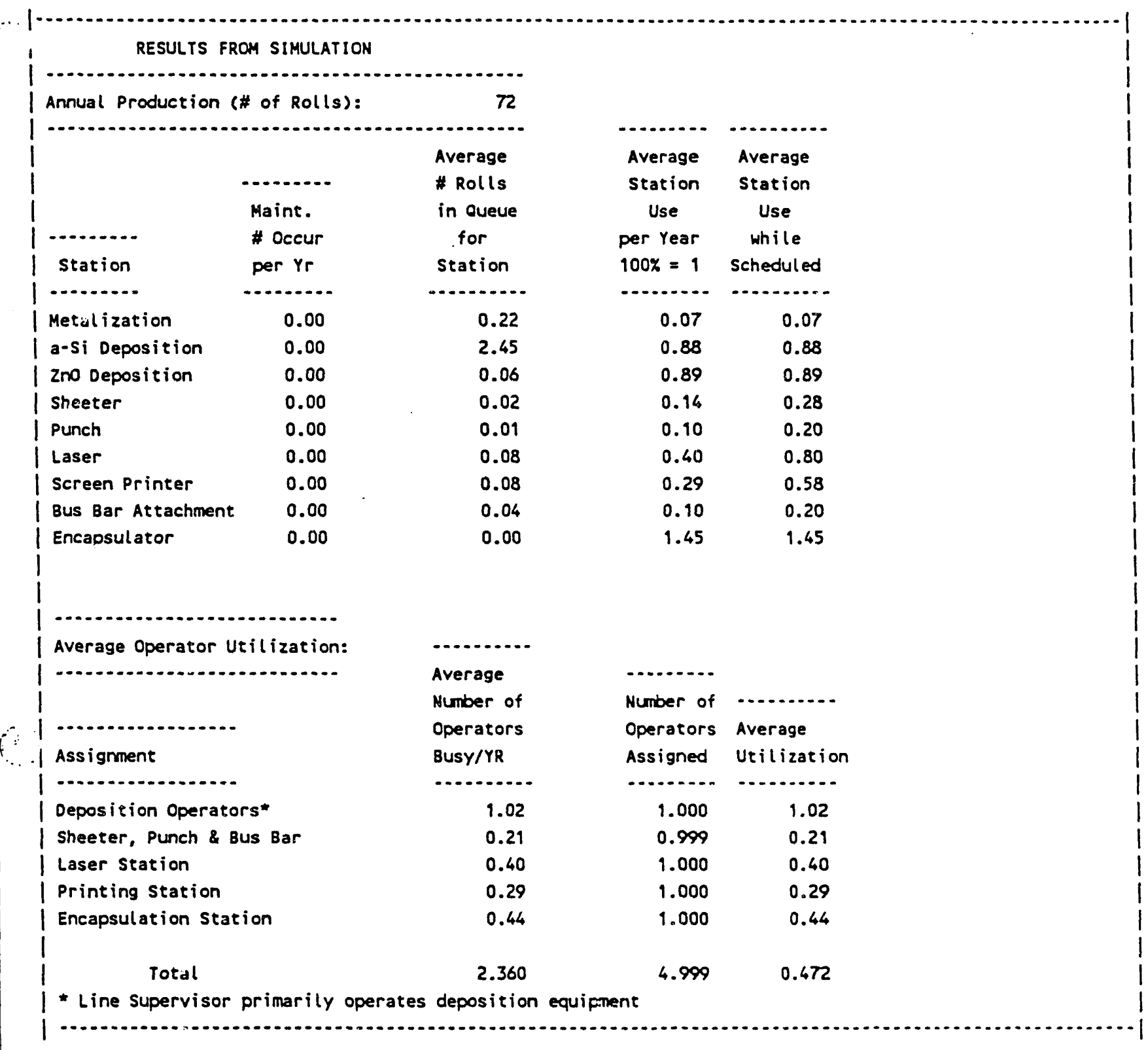


DIRECT PROOUCTION COST -- COST TO INSTALL AND OPERATE THE LINE

\begin{tabular}{|c|c|c|c|c|c|c|}
\hline & & AEC & 1st $\mathrm{Yr}$ & ECONOMIC IN & NPUT DATA: & \\
\hline & $\ldots$ & Including & Op Cost* & $\ldots \ldots \ldots$ & $\cdots$ & \\
\hline STATION DATA: & Numbe: & Op Cost* & (Pre-tax) & Deprcble & Non-Deprc & \\
\hline - n & Machines & per & per & First & First & Salvage \\
\hline Name & a station & Station & Station & Cost & Cost & (2S Yrs) \\
\hline 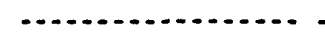 & $\ldots \ldots$ & $\ldots \ldots$ & $\cdots+\ldots$ & $\cdots+\ldots$ & $\cdots \ldots$ & $\cdots \ldots$ \\
\hline Metalization & 1 & 59312 & 1620 & 154000 & 120000 & 32500 \\
\hline a-Si Deposition & 1 & 126959 & 81245 & 220000 & 120000 & 50000 \\
\hline Zno Deposition & 1 & 84295 & 68141 & 81000 & 80000 & 10000 \\
\hline Sheeter & 1 & 17059 & 14168 & 20000 & 12500 & 2000 \\
\hline Punch & 1 & 16139 & 94168 & 15000 & 12500 & 1500 \\
\hline Laser & 1 & 85136 & 49358 & 108000 & 120000 & 25000 \\
\hline Screen Printer & 1 & 49116 & 42806 & 46000 & 40000 & 8000 \\
\hline Bus Bar Attachment & 1 & 18153 & 14168 & 30000 & 12500 & 10000 \\
\hline Encapsulator & 2 & 64525 & 84390 & 3000 & 12500 & 0 \\
\hline Total for Line: & 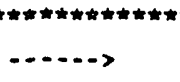 & 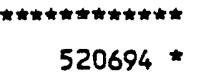 & 370063 & 677000 & 530000 & 139000 \\
\hline $\begin{array}{l}\text { Cost of Line Supe } \\
\text { The after-tax ist y }\end{array}$ & $\begin{array}{l}\text { ervisor is } n \\
\text { year cost is }\end{array}$ & $\begin{array}{l}\text { not included } \\
\text { s } 96533\end{array}$ & & 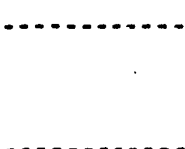 & & \\
\hline ANNUAL MACHINE OPER & RATING PARAM & METERS INPUT & & & & \\
\hline MACHINE DATA: & - & Scheduled & Labor & Power & Number & $\operatorname{Cos} t$ \\
\hline - n & Number & Operating & $\operatorname{Cos} t$ & Cost & Maintne & per Mntne| \\
\hline Station & Machines & Hrs per Yr & per $\mathrm{Hr}$ & per $\mathrm{Hr}$ & per $Y r$ & per \\
\hline Name & a station & per Mchn & per Mchn & per Mchn & per Mchn & Mchn \\
\hline (n. & $\cdots+\ldots$ & $\ldots$ & $\ldots$ & - & $\ldots \ldots$ & $\ldots \ldots . . . .$. \\
\hline Metalization & 1 & 900 & 0.00 & 1.80 & 0 & 0 \\
\hline a-si Deposition & 1 & 8736 & 7.50 & 1.80 & 0 & 0 \\
\hline Zno Deposition & 1 & 8736 & 7.50 & 0.30 & 0 & 0 \\
\hline Sheetir & 1 & 4368 & 3.16 & 0.08 & 0 & 0 \\
\hline Punch & 1 & 4368 & 3.16 & 0.08 & 0 & 0 \\
\hline Laser & 1 & 4368 & 9.50 & 1.80 & 0 & 0 \\
\hline Screen Printer & 1 & 4368 & 9.50 & 0.30 & 0 & 0 \\
\hline Bus Bar Attachment & 1 & 4368 & 3.16 & 0.08 & 0 & 0 \\
\hline Encapsulator & 2 & 8736 & 4.75 & 0.08 & 0 & 0 \\
\hline
\end{tabular}

Annual Equivalent Cost for Priming and Metalization Station

$\begin{array}{lr}\text { First Cost: } & 274000 \\ \text { Salvage: } & 32500 \\ \text { Operating Cost: } & 1620\end{array}$




\begin{tabular}{|c|c|c|c|c|c|c|}
\hline \multirow[b]{2}{*}{ End } & \multicolumn{4}{|c|}{ Annual } & \multicolumn{2}{|c|}{ After-Tax } \\
\hline & First & (ACRS) & Operating & & Tax & Cash \\
\hline Year & Cost & Deprec. & Expense & Salvage & Savings & Flow \\
\hline 0 & 274000 & & & & & \\
\hline 1 & & 23100 & 1620 & & 8652 & -7032 \\
\hline 2 & & 33880 & 1701 & & 12453 & -10752 \\
\hline 3 & & 32340 & 1786 & & 11944 & -10158 \\
\hline 4 & & 32340 & 1875 & & 11975 & -10100 \\
\hline 5 & & 32340 & 1969 & 32500 & 633 & -31164 \\
\hline & & 154000 & & & & \\
\hline
\end{tabular}

Present Value of After-Tax Cash Flow:

First cost of Equipment:

Total Present Value of Equipment:

224840

Annual Equivalent Cost to Install and Operate (5yr):

59312

Annual Equivalent Cost for a-Si Deposition Station

$\begin{array}{lr}\text { First Cost: } & 340000 \\ \text { Salvage: } & 50000 \\ \text { Operating Cost: } & 81245\end{array}$

\begin{tabular}{|c|c|c|c|c|c|c|}
\hline \multirow{3}{*}{$\begin{array}{l}\text { End } \\
\text { Year }\end{array}$} & \multirow{4}{*}{$\begin{array}{l}\text { First } \\
\text { Cost } \\
340000\end{array}$} & \multicolumn{3}{|c|}{ Annual } & \multicolumn{2}{|c|}{ After-Tax } \\
\hline & & (ACRS) & Operating & & $\operatorname{Tax}$ & Cash \\
\hline & & Deprec. & Expense & Salvage & Savings & Flow \\
\hline 0 & & & & & & \\
\hline 1 & & 33000 & 81245 & & 39986 & 41259 \\
\hline 2 & & 48400 & 85307 & & 46797 & 38510 \\
\hline 3 & & 46200 & 89572 & & 47520 & 42052 \\
\hline 4 & & 46200 & 94051 & & 49088 & 44963 \\
\hline 5 & & 46200 & 98754 & 50000 & 33234 & 15520 \\
\hline & & 220000 & & & & \\
\hline
\end{tabular}

Present Value of After-Tax Cash Flow:

141276

340000

First Cost of Equipment:

481276

Annual Equivalent Cost to Install and Operate (5yr):

126959

Anmual Equivalent Cost for Zno (top contact coating) Deposition station

$\begin{array}{lr}\text { First Cost: } & 161000 \\ \text { Salvage: } & 10000 \\ \text { Operating Cost: } & 68141\end{array}$

\begin{tabular}{|c|c|c|c|c|c|c|}
\hline \multirow{3}{*}{$\begin{array}{l}\text { End } \\
\text { Year }\end{array}$} & \multirow{3}{*}{$\begin{array}{l}\text { First } \\
\text { Cost }\end{array}$} & \multicolumn{3}{|c|}{ Annual } & \multicolumn{2}{|c|}{ After-Tax } \\
\hline & & (ACRS) & Operating & & $\operatorname{Tax}$ & Cash \\
\hline & & Deprec. & Expense & Salvage & Savings & Flow \\
\hline 1 & & 12150 & 68141 & & 28102 & 40039 \\
\hline 2 & & 17820 & 71548 & & 31279 & 40269 \\
\hline
\end{tabular}




$\begin{array}{llllll}3 & 17010 & 75125 & & 32247 & 42878 \\ 4 & 17010 & 78881 & & 33562 & 45319 \\ 5 & 17010 & 82826 & 10000 & 31442 & 41383 \\ & 81000 & & & & \end{array}$

Present Value of After-Tax Cash Flow: $\quad 158544$

First Cost of Equipment:

161000

Total Present Value of Operating Station:

319544

Annual Equivalent Cost to Install and Operate (5yr):

84295

Annual Equivalent Cost for Sheet Cutting Station

$\begin{array}{lr}\text { First Cost: } & 32500 \\ \text { Salvage: } & 2000 \\ \text { Operating Cost: } & 14168\end{array}$

$\begin{array}{rrrrrrr}\text { End } & \text { First } & \begin{array}{c}\text { Annual } \\ \text { (ACRS) } \\ \text { Year }\end{array} \begin{array}{c}\text { Cost } \\ \text { Deprec. }\end{array} & \begin{array}{c}\text { After-Tax } \\ \text { Expense }\end{array} & \text { Salvage } & \begin{array}{c}\text { Tax } \\ \text { Savings }\end{array} & \begin{array}{c}\text { Cash } \\ \text { Flow }\end{array} \\ 0 & 32500 & & & & 6009 & 8159 \\ 1 & & 3000 & 14168 & 6747 & 8129 \\ 2 & 4400 & 14876 & & 6937 & 8683 \\ 3 & 4200 & 15620 & & 7210 & 9191 \\ 4 & 4200 & 16401 & & 6797 & 8424 \\ 5 & 4200 & 17221 & 2000 & & \end{array}$

Present Value of After-Tax Cash Flow: $\quad 32167$

First Cost of Equipment: $\quad 32500$

$\begin{array}{ll}\text { Total Present Value of Operating Station: } & 64667\end{array}$

Annual Equivalent cost to Install and Operate (5yr): 17059

Annual Equivalent Cost for Sheet Punching Station

$\begin{array}{lr}\text { First Cost: } & 27500 \\ \text { Salvage: } & 1500 \\ \text { Operating Cost: } & 14168\end{array}$

\begin{tabular}{|c|c|c|c|c|c|c|}
\hline \multirow[b]{2}{*}{$\begin{array}{l}\text { End } \\
\text { Year }\end{array}$} & \multirow[b]{2}{*}{$\begin{array}{l}\text { First } \\
\text { Cost }\end{array}$} & \multicolumn{2}{|r|}{ Annual } & \multicolumn{3}{|c|}{ After-Tax } \\
\hline & & $\begin{array}{l}\text { (ACRS) } \\
\text { Deprec. }\end{array}$ & $\begin{array}{c}\text { Operating } \\
\text { Expense }\end{array}$ & Salvage & $\begin{array}{c}\text { Tax } \\
\text { Savings }\end{array}$ & $\begin{array}{l}\text { Cash } \\
\text { Flow }\end{array}$ \\
\hline 0 & 27500 & & & & & \\
\hline 1 & & 2250 & 14168 & & 5746 & 8421 \\
\hline 2 & & 3300 & 14876 & & 6362 & 8514 \\
\hline 3 & & 3150 & 15620 & & 6569 & 9050 \\
\hline 4 & & 3150 & 16409 & & 6843 & 9558 \\
\hline 5 & & 3150 & 17221 & 1500 & 6605 & 9116 \\
\hline & & 15000 & & & & \\
\hline
\end{tabular}

Present Value of After-Tax Cash Flow: 
First Cost of Equipment:

Total Present Value of Operating Station:

Annual Equivalent Cost to Install and Operate (5yr):

Annual Equivalent Cost for Laser Scribing Station

$\begin{array}{lr}\text { First Cost: } & 228000 \\ \text { Salvage: } & 25000 \\ \text { Operating Cost: } & 49358\end{array}$

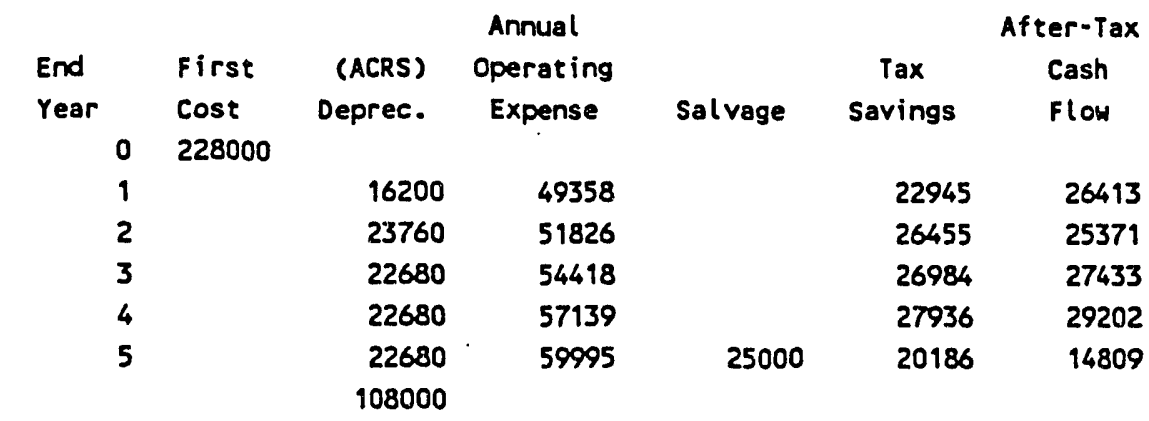

Present Value of After-Tax Cash Flow:

Total Present Value of Operating Station:

322731

Annual Equivalent Cost to Install and Operate (5yr):

85136

Annual Equivalent Cost for Screen Printing station

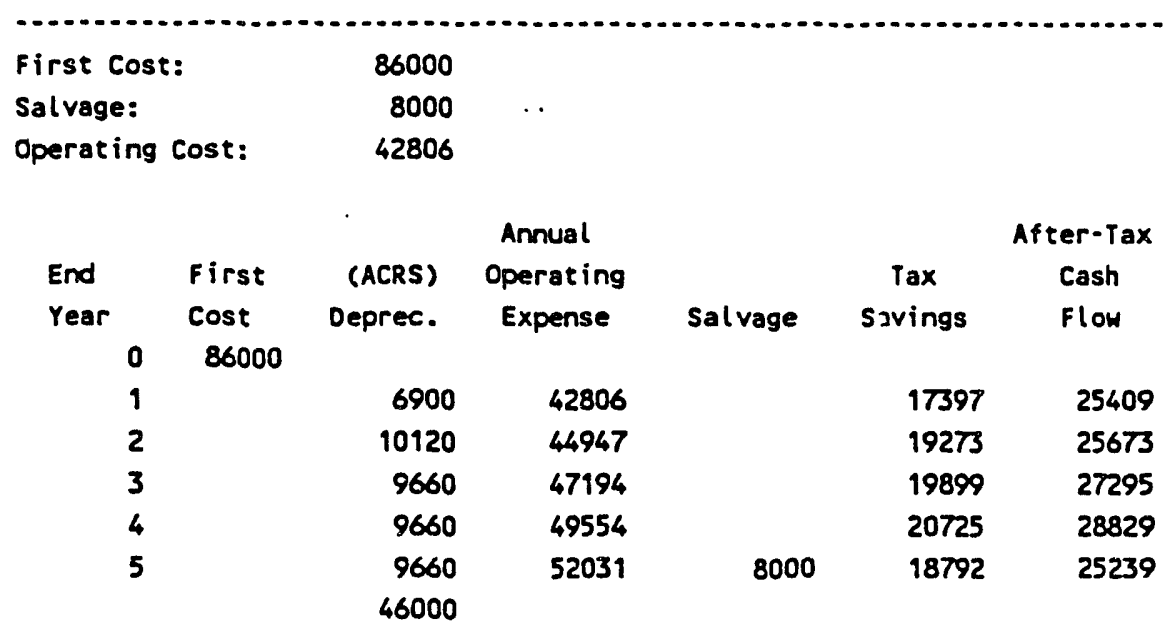

Present Value of After-Tax Cash Flow:

100186

86000

First Cost of Equipment:

186186

Total Present Value of Operating station:

49116

Annual Equivalent Cost to Install and Operate (5yr): 
Annual Equivalent Cost for Bus Bar Attachment station

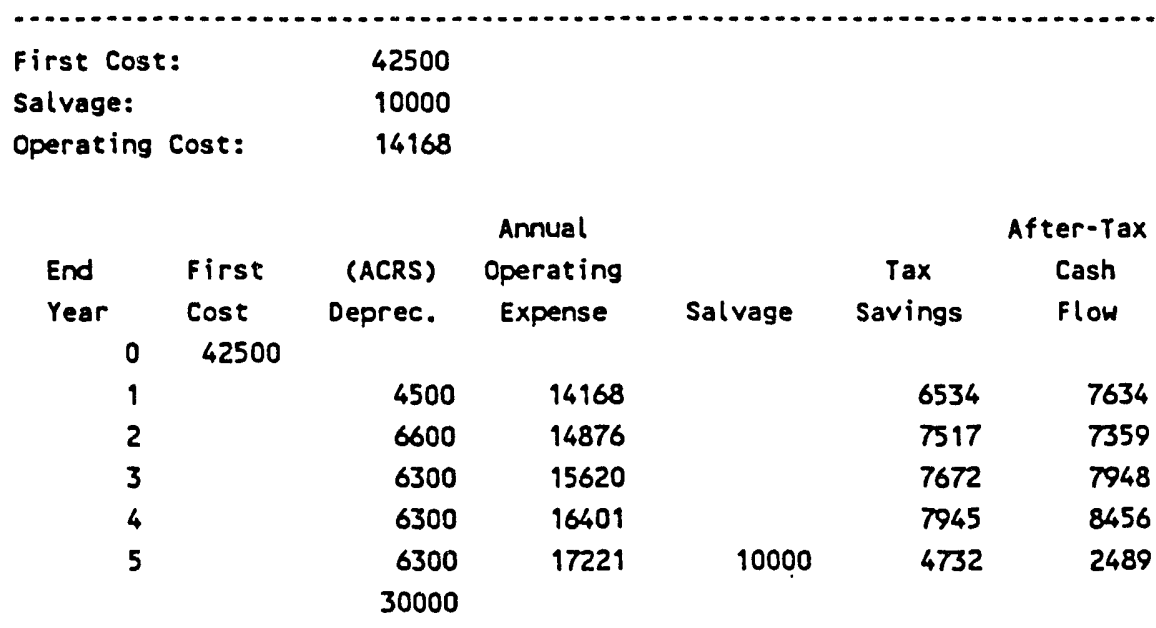

Present Value of After-Tax Cash Flow: 26314

First Cost of Equipment: 42500

Total Present Value of Operating Station: 88814

Annual Equivalent Cost to Install and Operate (5yr): $\quad 18153$

Annual Equivalent Cost for Encapsulation Station

First Cost: $\quad 18500$

Operating Cost: $\quad 84390$

\begin{tabular}{|c|c|c|c|c|c|c|}
\hline \multirow{3}{*}{$\begin{array}{l}\text { End } \\
\text { Year }\end{array}$} & \multicolumn{4}{|c|}{ Annual } & \multicolumn{2}{|c|}{ After-Tax } \\
\hline & First & (ACRS) & Operating & & Tax & Cash \\
\hline & $\cos t$ & Deprec. & Expense & Salvage & Savings & Flow \\
\hline 0 & 18.500 & & & & & \\
\hline 1 & & 900 & 84390 & & 29851 & 54538 \\
\hline 2 & & 1320 & 88609 & & 31475 & 57134 \\
\hline 3 & & 1260 & 93040 & & 33005 & 60035 \\
\hline 4 & & 1260 & 97692 & & 34633 & 63059 \\
\hline 5 & & 1260 & 102576 & 0 & 36343 & 66234 \\
\hline & & & & & & \\
\hline
\end{tabular}

Present Value of After-Tax Cash Flow: 226099

First Cost of Equipment:

18500

Total Present Value of Operating Station: $\quad 244599$

Annual Equivalent Cost to Install and Operate (5yr): 64525 


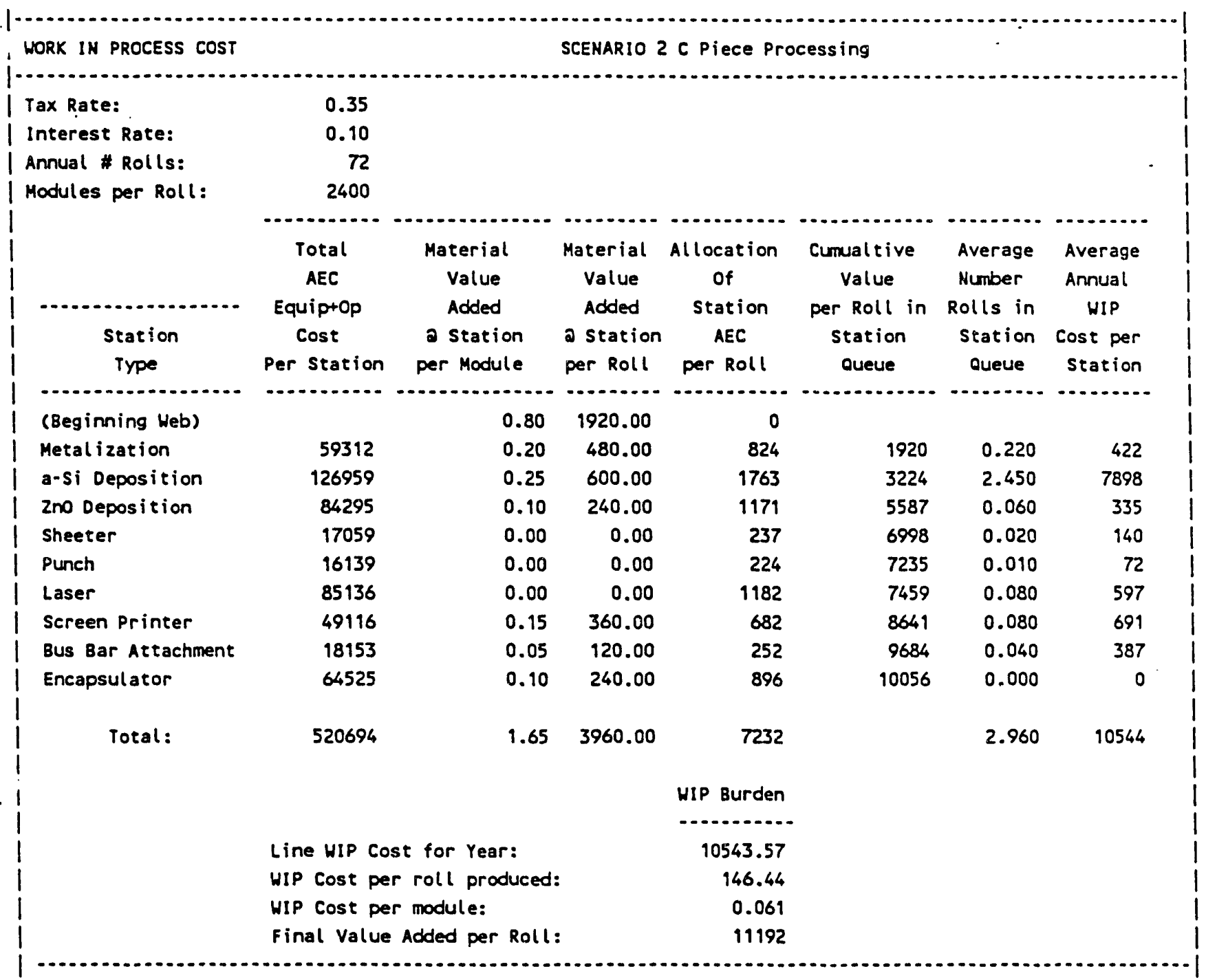




\section{SCENARIO $3 \mathrm{~A}$}

INPUT DATA REQUIRED FOR ANALYSIS DATE EVALUATED: $3 / 27 / 91$

Name of Scenario Being Evaluated: SCENARIO 3 A Roll-to-Roll with Etch

Yield per Roll Produced (\# of modules 2400

Average Watts per Module:

Tax Rate: $\quad 0.35$

Interest Rate: $\quad 0.10$

Labor Rate per/hr for line supervisor 17.00

\begin{tabular}{|c|c|c|c|c|c|c|c|}
\hline \multirow{2}{*}{ station Input Data } & \multicolumn{5}{|c|}{ 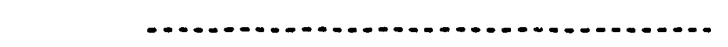 } & \multirow{3}{*}{$\begin{array}{l}\text { Effective } \\
\text { Operator } \\
\text { Rate } \\
\text { per } \mathrm{Hr}\end{array}$} & \multirow{3}{*}{$\begin{array}{l}\text { Cost of } \\
\text { Material/Module } \\
\text { When it reaches } \\
\text { Station }\end{array}$} \\
\hline & . & first & First & Salvage & Operators & & \\
\hline & Number & $\operatorname{Cos} t$ & Cost & (25 Yrs) & a station & & \\
\hline - & -.... & ......... & a........ & (n) & (n) & 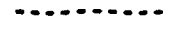 & $\cdots+\cdots$ \\
\hline Metalization & 1 & 154000 & 120000 & 32500 & 0.000 & 0.00 & 0.80 \\
\hline a-si Deposition & 1 & 220000 & 120000 & 50000 & 0.167 & 15.00 & 1.00 \\
\hline Zno Deposition & 1 & 81000 & 80000 & 10000 & 0.167 & 15.00 & 1.25 \\
\hline Sheeter & 1 & 20000 & 12500 & 2000 & 0.000 & 9.50 & 1.35 \\
\hline Punch & 0 & 15000 & 12500 & 1500 & 0.000 & 9.50 & 1.35 \\
\hline Laser & 1 & 108000 & 120000 & 25000 & 0.333 & 15.00 & 1.35 \\
\hline Screen Printer & 1 & 46000 & 40000 & 8000 & 0.333 & 15.00 & 1.35 \\
\hline Bus Bar Attachment & 1 & 30000 & 12500 & 10000 & 0.000 & 9.50 & 1.50 \\
\hline Encapsulator & 2 & 3000 & 12500 & 0 & 1.000 & 9.50 & 1.55 \\
\hline & & & & & & & 1.65 aend \\
\hline
\end{tabular}




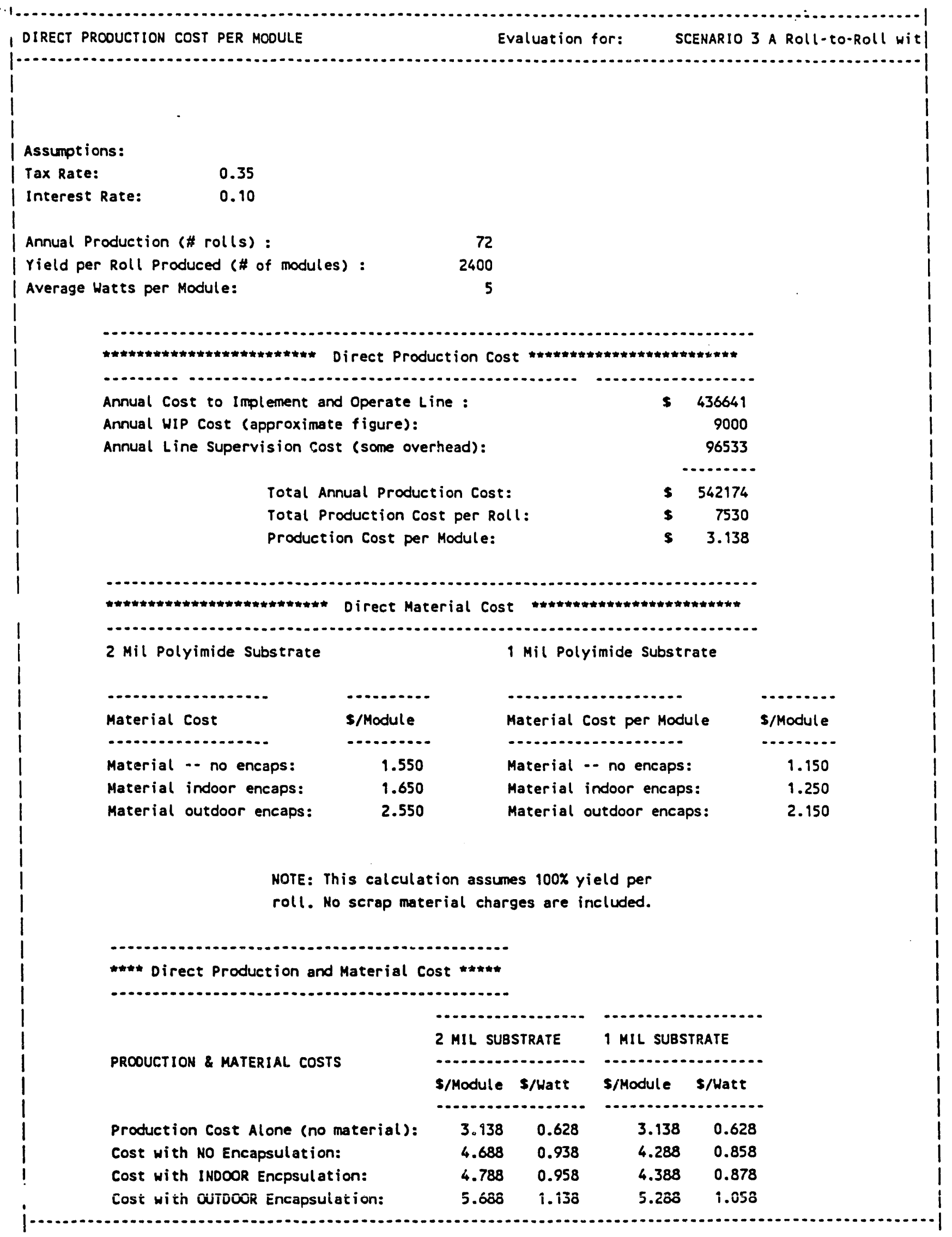




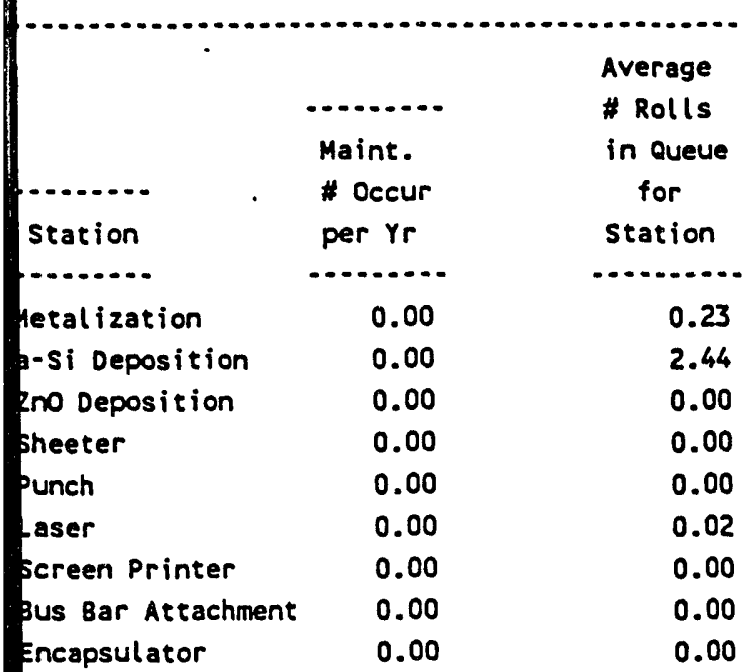

$\begin{array}{cc}\text { Average } & \begin{array}{c}\text { Average } \\ \text { Station } \\ \text { Station } \\ \text { Use }\end{array} \\ \text { per Year } & \begin{array}{c}\text { while } \\ 100 \%=1\end{array} \\ \text { Scheduled } \\ 0.07 & 0.07 \\ 0.88 & 0.88 \\ 0.91 & 0.91 \\ 0.02 & 0.02 \\ 0.00 & 0.00 \\ 0.40 & 0.40 \\ 0.43 & 0.43 \\ 0.12 & 0.12 \\ 1.58 & 1.58\end{array}$

\section{Average Operator Utilization:}

\section{Assigment}

Deposition Operators*

Sheeter, Punch \& Bus Bar Laser Station

Printing station

Encapsulation station

Average
Number of
Operators
Busy
1.17
N/A
N/A
N/A
0.62
1.790

-..........

Number of

Operators

Assigned

Average

Assigned Utilization

$0.334 \quad 3.50$

$\begin{array}{lll}\text { N/A } & 0.000 & \text { ERR } \\ \text { N/A } & 0.333 & 0.00\end{array}$

N/A $\quad 0.333 \quad 0.00$

$\begin{array}{lll}02 & 1.000 & 0.62\end{array}$

Total

1.790

2.000

0.895

- Line Supervisor primarily operates deposition equipment 


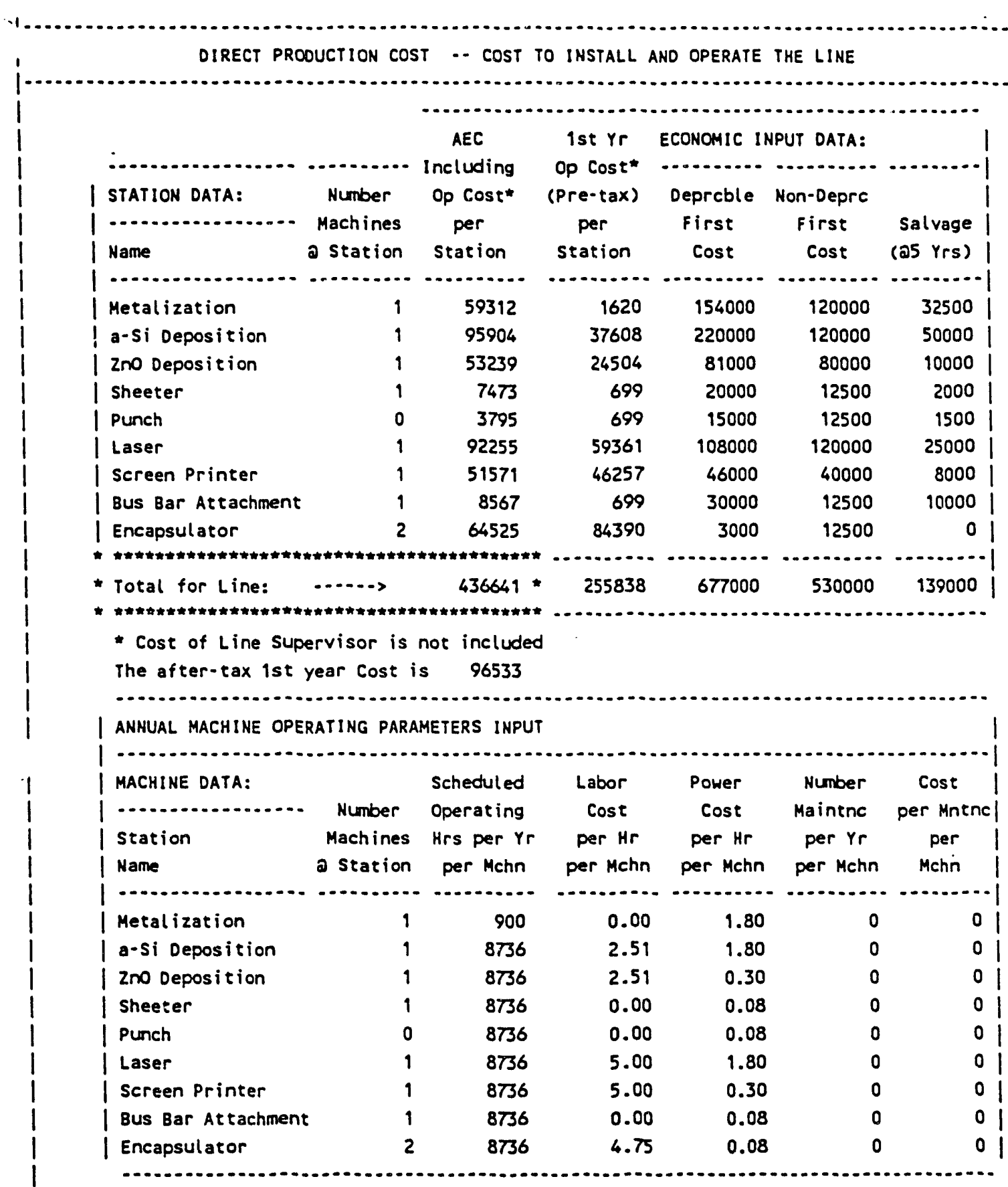

Annual Equivalent cost for Priming and Metalization station

$\begin{array}{lr}\text { First Cost: } & 274000 \\ \text { Salvage: } & 32500 \\ \text { Operating Cost: } & 1620\end{array}$




\begin{tabular}{rlrrrrr} 
End & First & $\begin{array}{r}\text { Annual } \\
\text { (ACRS) } \\
\text { Year }\end{array}$ & $\begin{array}{c}\text { Cost } \\
\text { Operating } \\
\text { Expense }\end{array}$ & Salvage & $\begin{array}{c}\text { Tax } \\
\text { Savings }\end{array}$ & $\begin{array}{c}\text { After-Tax } \\
\text { Cash } \\
\text { Flow }\end{array}$ \\
\hline & 274000 & & & & & \\
1 & & 23100 & 1620 & & 1652 & -7032 \\
2 & 33880 & 1701 & & 1953 & -10752 \\
3 & 32340 & 1786 & & 1944 & -10158 \\
4 & 32340 & 1875 & & 11975 & -10100 \\
5 & 32340 & 1969 & 32500 & 633 & -31164 \\
& 154000 & & & &
\end{tabular}

Present Value of After-Tax Cash Flow: $\quad-49160$

First Cost of Equipment:

274000

224840

Total Present Value of Equipment:

59312

Annual Equivalent Cost to Install and Operate (5yr):

Annual Equivalent Cost for a-si Deposition Station

\begin{tabular}{|c|c|c|c|c|c|c|}
\hline First Cos & & $\begin{array}{r}340000 \\
50000\end{array}$ & & & & \\
\hline \multirow[t]{2}{*}{ Operating } & Cost: & 37608 & & & & \\
\hline & \multicolumn{5}{|c|}{ Annual } & After-Tax \\
\hline End & First & (ACRS) & Operating & & $\operatorname{Tax}$ & Cash \\
\hline Year & Cost & Deprec. & Expense & Salvage & Savings & Flow \\
\hline 0 & 340000 & & & & & \\
\hline 1 & & 33000 & 37608 & & 24713 & 12896 \\
\hline 2 & & 48400 & 39489 & & 30761 & 8728 \\
\hline 3 & & 46200 & 41463 & & 30682 & 10781 \\
\hline 4 & & 46200 & 43537 & & 31408 & 12129 \\
\hline 5 & & 46200 & 45713 & 50000 & 14670 & -18956 \\
\hline & & 220000 & & & & \\
\hline
\end{tabular}

Present Value of After-Tax Cash Flow:

23550

340000

First Cost of Equipment:

363550

Total Present Value of Equipment:

95904

Annual Equivalent Cost to Install and Operate (5yr):

Annual Equivalent Cost for 2 no (top contact coating) Deposition Station

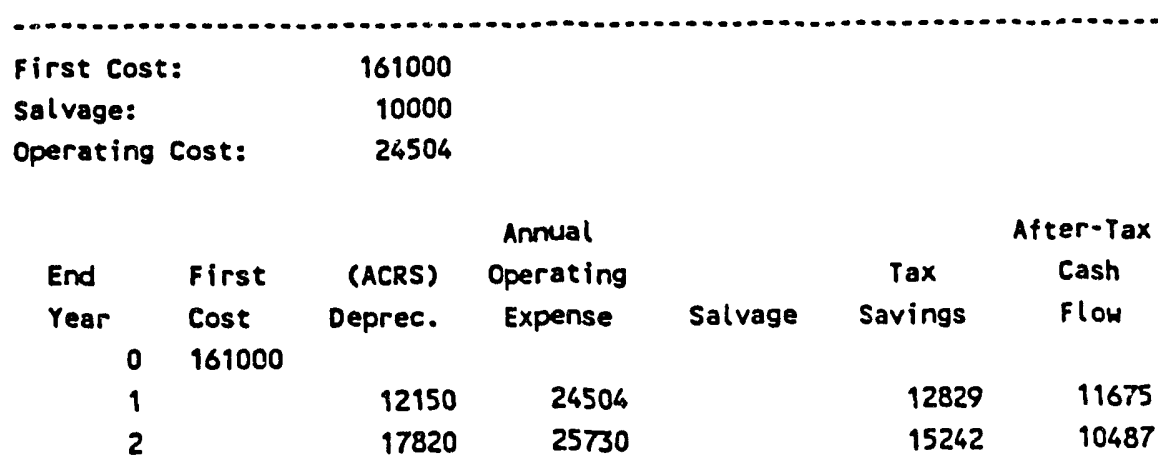




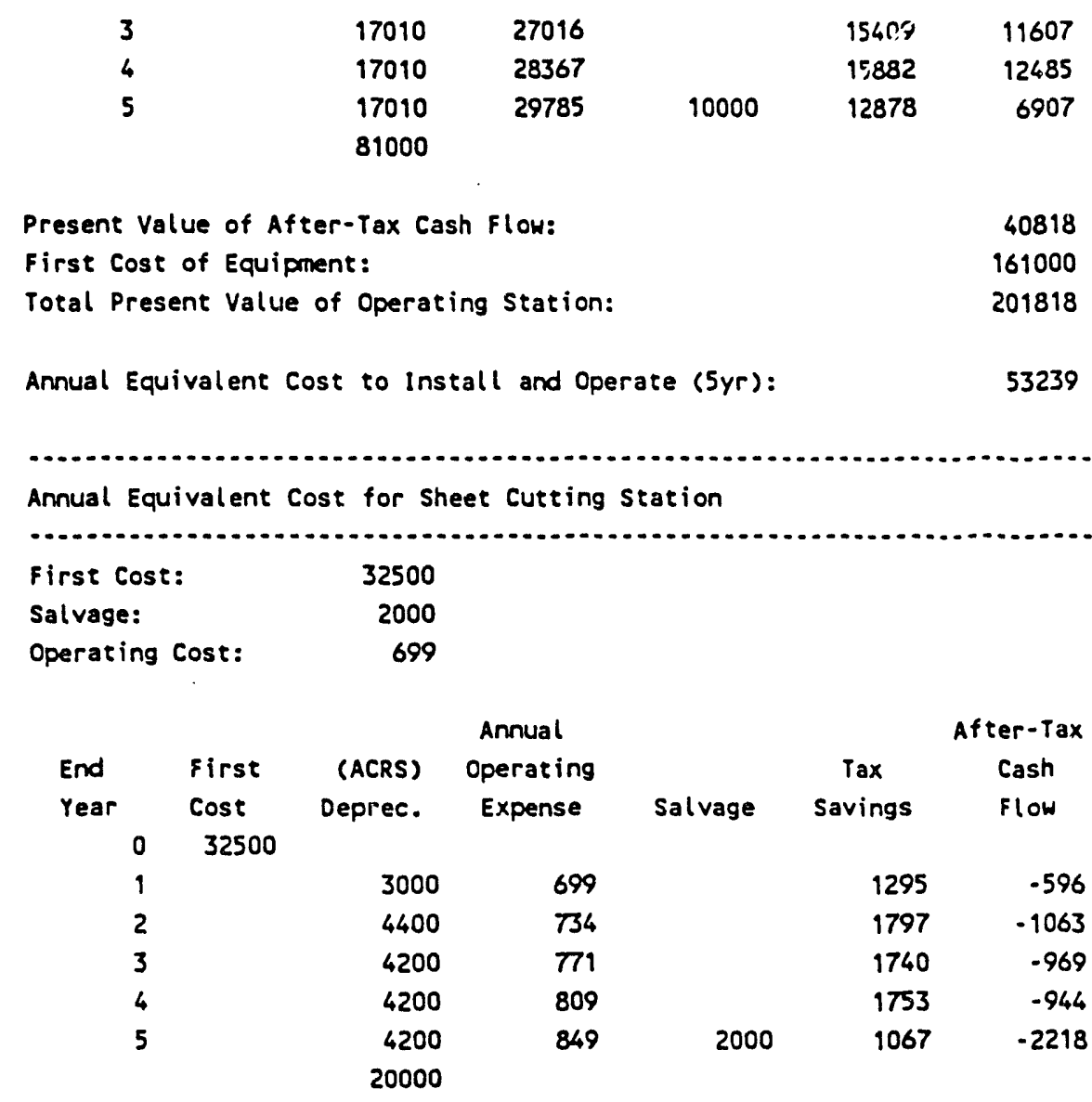

Present Value of After-Tax Cash Flow:

First Cost of Equipment:

32500

Total Present Value of Operating Station:

28330

Annual Equivalent Cost to Install and Operate (5yr):

7473

Annual Equivalent Cost for Sheet Punching station

$\begin{array}{lr}\text { First Cost: } & 12500 \\ \text { Salvage: } & 0 \\ \text { Operating Cost: } & 699\end{array}$

\begin{tabular}{|c|c|c|c|c|c|c|}
\hline \multirow{3}{*}{$\begin{array}{l}\text { End } \\
\text { Year }\end{array}$} & \multicolumn{4}{|c|}{ Annual } & \multicolumn{2}{|c|}{ After-Tax } \\
\hline & First & (ACRS) & operating & & $\operatorname{Tax}$ & Cash \\
\hline & Cost & Deprec. & Expense & Salvage & Savings & Flow \\
\hline 0 & 12500 & & & & & \\
\hline 1 & & 0 & 699 & & 245 & 454 \\
\hline 2 & & 0 & 734 & & 257 & 477 \\
\hline 3 & & 0 & 771 & & 270 & 501 \\
\hline 4 & & 0 & 809 & & 283 & 526 \\
\hline 5 & & 0 & 849 & 0 & 297 & 552 \\
\hline & & 0 & & & & \\
\hline
\end{tabular}


First Cost of Equipment:

Total Present Value of Operating Station:

Annual Equivalent Cost for Laser Scribing Station

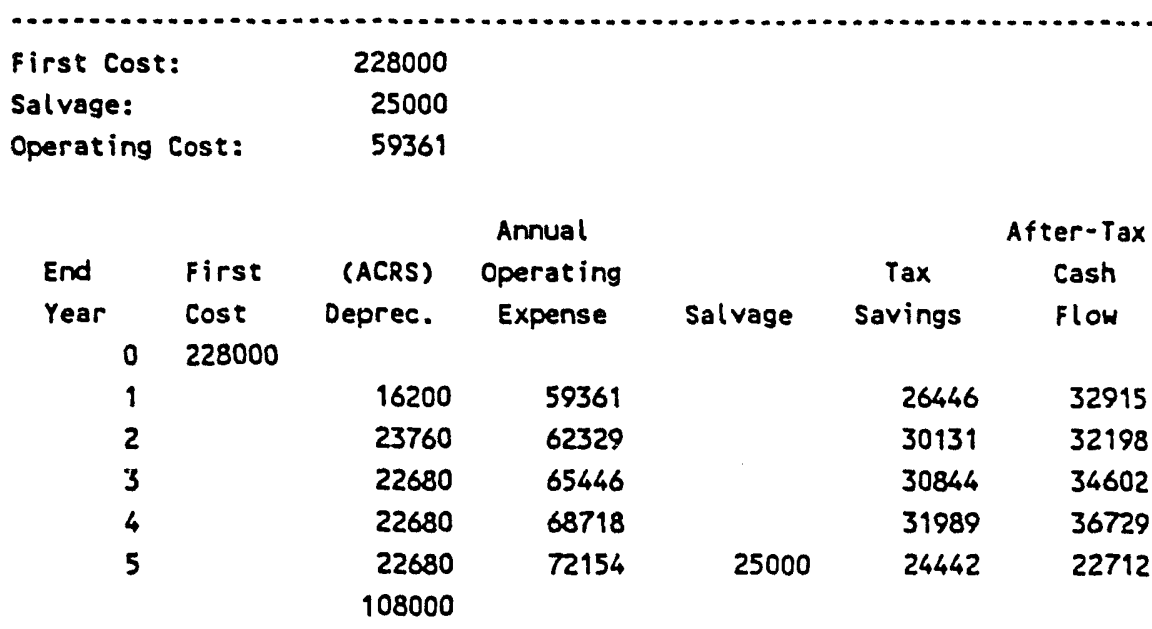

Present Value of After-Tax Cash Flow: 121718

121718

First Cost of Equipment:

Total Present Value of Operating Station: 349718

Annual Equivalent cost to Install and Operate (5yr): 92255

Annual Equivalent cost for screen Printing station

\begin{tabular}{|c|c|c|c|c|c|c|}
\hline \multicolumn{2}{|c|}{ First Cost: } & 86000 & & & & \\
\hline \multicolumn{2}{|l|}{ Salvage: } & 8000 & & & & \\
\hline \multirow[t]{2}{*}{ Operating } & $\cos t:$ & 46257 & & & & \\
\hline & & & Annual & & & ter-Tax \\
\hline \multirow{2}{*}{$\begin{array}{l}\text { End } \\
\text { Year }\end{array}$} & First & (ACRS) & Operating & & $\operatorname{Tax}$ & Cash \\
\hline & $\operatorname{Cos} t$ & Deprec. & Expense & Salvage & Savings & Flow \\
\hline 0 & 86000 & & & & & \\
\hline 1 & & 6900 & 46257 & & 18605 & 27652 \\
\hline 2 & & 10120 & 48570 & & 20541 & 28023 \\
\hline 3 & & 9660 & 50998 & & 21230 & 29768 \\
\hline 4 & & 9660 & 53548 & & 22123 & 31425 \\
\hline 5 & & 9660 & 56226 & 8000 & 20260 & 27966 \\
\hline & & 46000 & & & & \\
\hline
\end{tabular}

Present Value of After-Tax Cash Flow:

First Cost of Equipment:

Total Present Value of Operating Station:

195496

Annual Equivalent cost to Install and Operate (5yr): 51571 
Annual Equivalent Cost for Bus bar Attachment Station

$\begin{array}{ll}\text { First Cost: } & 42500 \\ \text { Salvage: } & 10000\end{array}$

Operating Cost:

699

\begin{tabular}{|c|c|c|c|c|c|c|}
\hline \multirow{3}{*}{$\begin{array}{l}\text { End } \\
\text { Year }\end{array}$} & \multicolumn{4}{|c|}{ Annual } & \multicolumn{2}{|c|}{ After-Tax } \\
\hline & First & (ACRS) & Operating & & $\operatorname{Tax}$ & Cash \\
\hline & Cost & Deprec. & Expense & Salvage & Savings & Flow \\
\hline 0 & 42500 & & & & & \\
\hline 1 & & 4500 & 699 & & 1820 & -1121 \\
\hline 2 & & 6600 & 734 & & 2567 & -1833 \\
\hline 3 & & 6300 & $\pi 1$ & & 2675 & -1704 \\
\hline 4 & & 6300 & 809 & & 2688 & .9679 \\
\hline 5 & & 6300 & 849 & 10000 & .998 & -8153 \\
\hline & & 30000 & & & & \\
\hline
\end{tabular}

Present Value of After-Tax Cash Flow:

First Cost of Equipment:

Total Present Value of Operating Station:

Annual Equivalent cost to Install and Operate (5yr):

8567

Annual Equivalent Cost for Encapsulation Station

$\begin{array}{lr}\text { First Cost: } & 18500 \\ \text { Salvage: } & 0 \\ \text { Operating Cost: } & 84390\end{array}$

Operating Cost: $\quad 84390$

\begin{tabular}{|c|c|c|c|c|c|c|}
\hline \multirow{3}{*}{$\begin{array}{l}\text { End } \\
\text { Year }\end{array}$} & \multirow{3}{*}{$\begin{array}{l}\text { First } \\
\text { Cost }\end{array}$} & \multicolumn{2}{|r|}{ Annual } & \multicolumn{3}{|c|}{ After-Tax } \\
\hline & & (ACRS) & Operating & & $\operatorname{Tax}$ & Cash \\
\hline & & Deprec. & Expense & Salvage & Savings & Flow \\
\hline 0 & 18500 & & & & & \\
\hline 1 & & 900 & 84390 & & 29851 & 54538 \\
\hline 2 & & 1320 & 88609 & & 31475 & 57134 \\
\hline 3 & & 1260 & 93040 & & 33005 & 60035 \\
\hline 4 & & 1260 & 97692 & & 34633 & 63059 \\
\hline 5 & & 1260 & 102576 & 0 & 36343 & 66234 \\
\hline & & 6000 & & & & \\
\hline
\end{tabular}

Present Value of After-Tax Cash Flow:

226099

18500

First Cost of Equipment:

244599

Annual Equivalent cost to Install and operate (5yr):

64525 


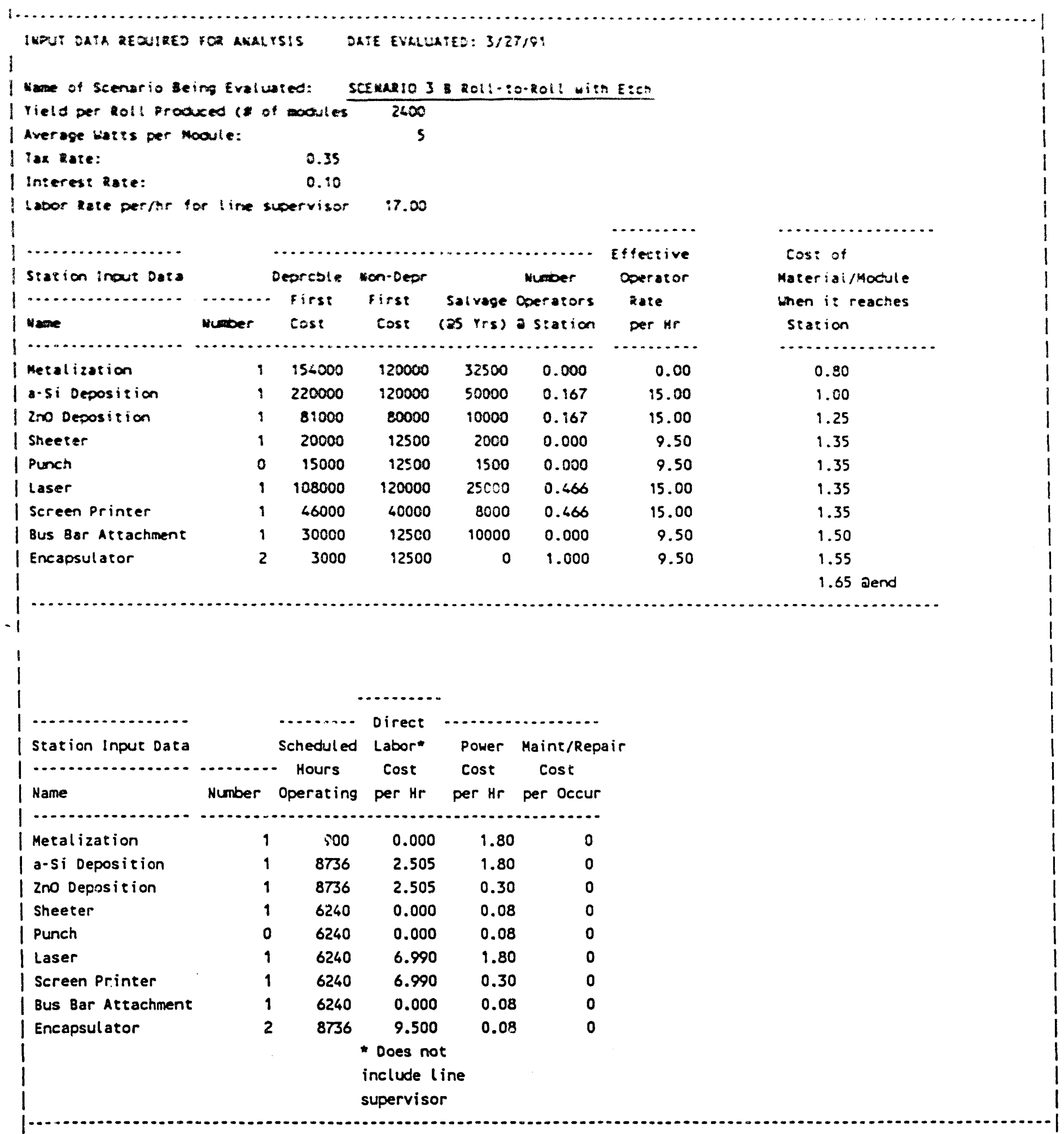




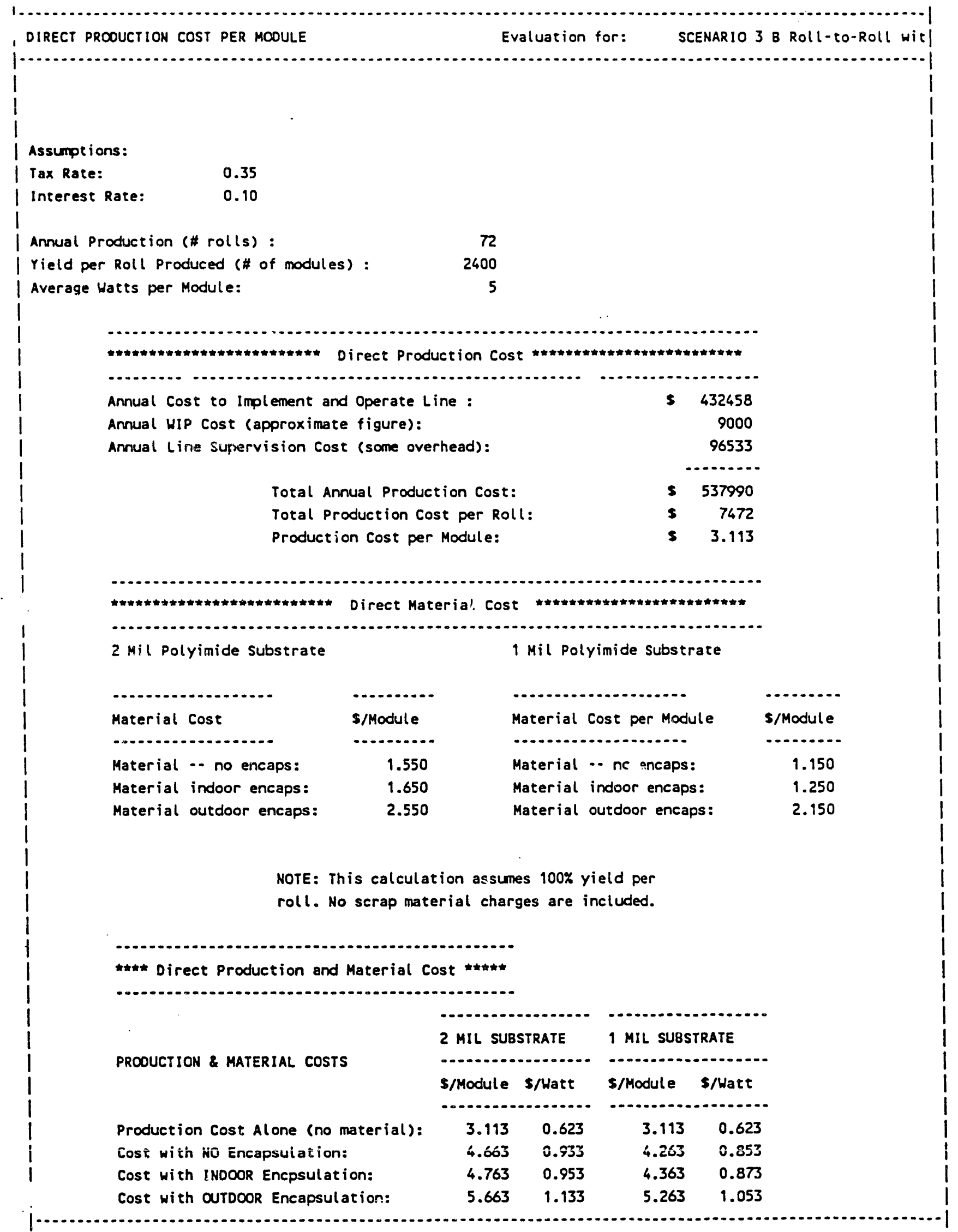




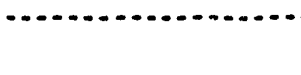

$\begin{array}{cc}\text { Maint. } & \begin{array}{c}\text { Average } \\ \text { \# Rolls }\end{array} \\ \text { \# occur } & \begin{array}{c}\text { in Queue } \\ \text { for }\end{array} \\ \ldots . . . . . . & \text { Station } \\ 0.00 & \ldots .22 \\ 0.00 & 2.43 \\ 0.00 & 0.10 \\ 0.00 & 0.00 \\ 0.00 & 0.00 \\ 0.00 & 0.02 \\ 0.00 & 0.00 \\ 0.00 & 0.01 \\ 0.00 & 0.00\end{array}$

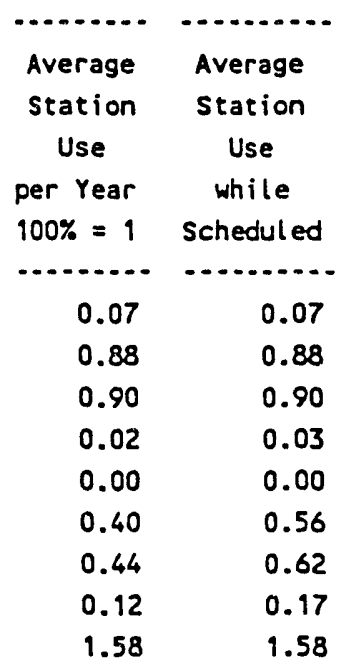

Average Operator Utilization:

station

Metalization

a-si Deposition

Zno Deposition

Sheeter

Punch

Laser

Screen Printer

Bus Bar Attachment

Encapsulator

0.00

Average

Number of

Operators

Busy

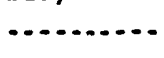

1.17

N/A

N/A

N/A

0.62
Number of

Operators

Assigned

Average

Utilization

0.334

0.000

3.50

0.466

0.466

1.000

2.266
ERR

0.00

0.00

0.62

0.790

Total

1.790

1 * Line Supervisor primarily operates deposition equipment 


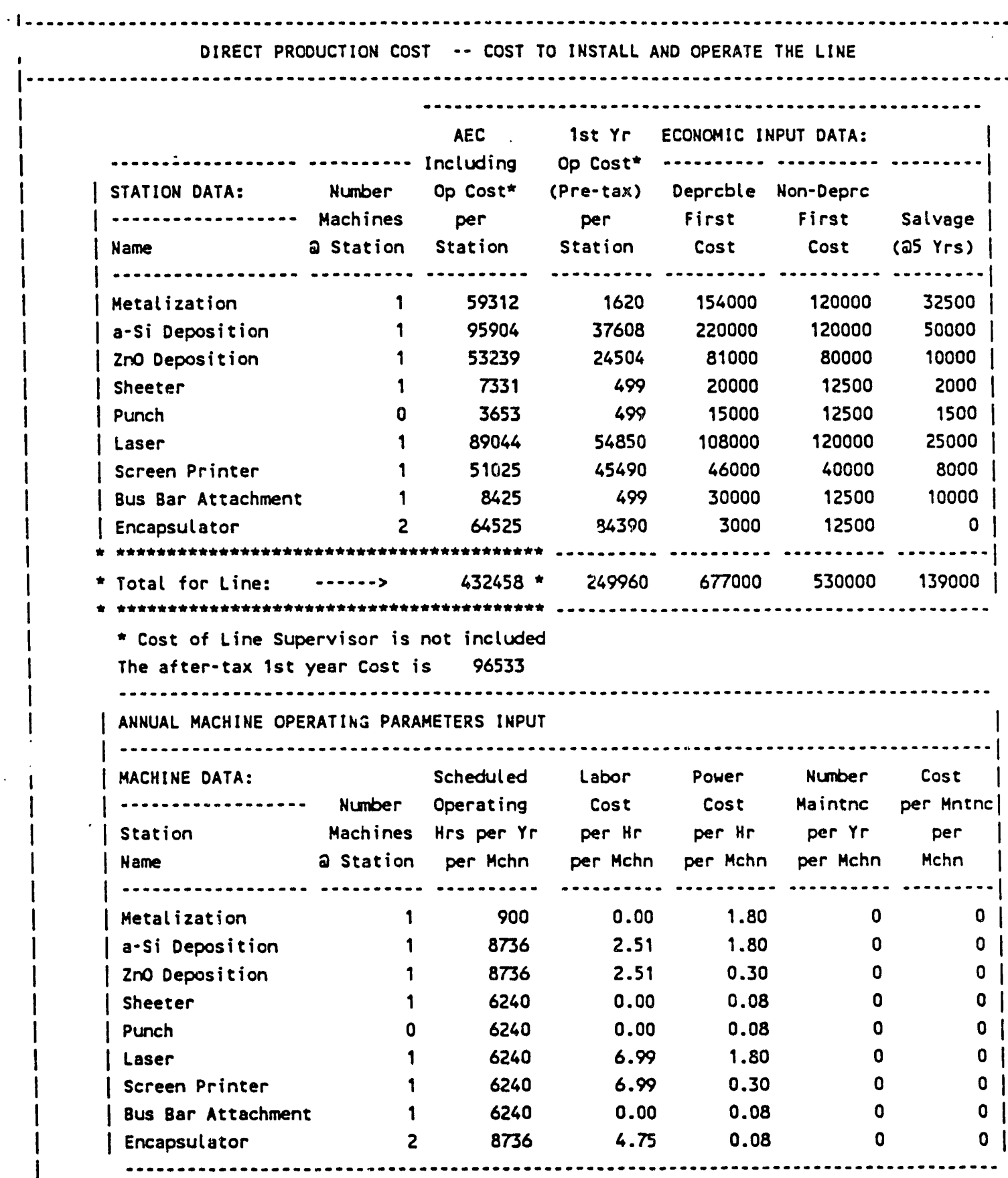

Annual Equivalent Cost for Priming and Metalization Station

$\begin{array}{lr}\text { First Cost: } & 274000 \\ \text { Salvage: } & 32500 \\ \text { Óperating Cost: } & 16020\end{array}$




\begin{tabular}{|c|c|c|c|c|c|c|}
\hline \multirow{3}{*}{$\begin{array}{l}\text { End } \\
\text { Year }\end{array}$} & \multicolumn{4}{|c|}{ Annual } & \multicolumn{2}{|c|}{ After-Tax } \\
\hline & First & (ACRS) & Operating & & $\operatorname{Tax}$ & Cash \\
\hline & Cost & Deprec. & Expense & Salvage & Savings & Flow \\
\hline 0 & 274000 & & & & & \\
\hline 1 & & 23100 & 1620 & & 8652 & $\because J 32$ \\
\hline 2 & & 33880 & 1701 & & 12453 & -10752 \\
\hline 3 & & 32340 & 1786 & & 11944 & -10158 \\
\hline 4 & & 32340 & 1873 & & 11975 & -10100 \\
\hline 5 & & 32340 & 1969 & 32500 & 633 & -31164 \\
\hline & & 154000 & & & & \\
\hline
\end{tabular}

Present Value of After-Tax Cash Flow: $\quad-49160$

First Cost of Equipment: $\quad 274000$

Total Present Valise of Equipment: 224840

Annual Equivalent cost to Install and Operate (5yr): 59312

Annual Equivalent linst for a-si Deposition Station

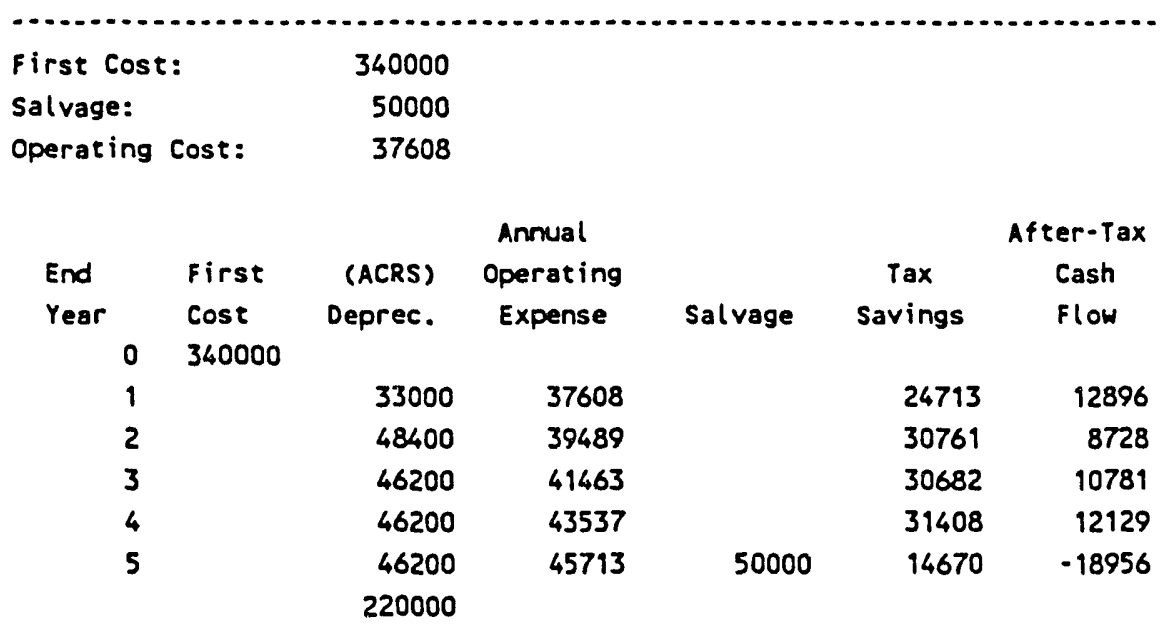

Present Value of After-Tax Cash Flow: 23550

First Cost of Equipment:

Total Present Value of Equipment:

363550

Annual Equivalent Cost to Install and Operate (5yr): 95904

Annual Equivalent Cost for 2 no (top contact coating) Deposition Station

\begin{tabular}{|c|c|c|c|c|c|c|}
\hline \multicolumn{2}{|c|}{ First Cost: } & 161000 & & & & \\
\hline \multicolumn{2}{|l|}{ Salvage: } & 10000 & & & & \\
\hline \multirow[t]{2}{*}{ Operating } & Cost: & 24504 & & & & \\
\hline & & & Annual & & & f ter-Tax \\
\hline End & First & (ACRS) & Operating & & Tax & Cash \\
\hline Year & $\operatorname{Cos} t$ & Deprec. & Expense & Salvage & Savings & Flow \\
\hline 0 & 161000 & & & & & \\
\hline$q$ & & 12150 & 24504 & & 12829 & 11675 \\
\hline 2 & & 17820 & 25730 & & 15242 & 10487 \\
\hline
\end{tabular}




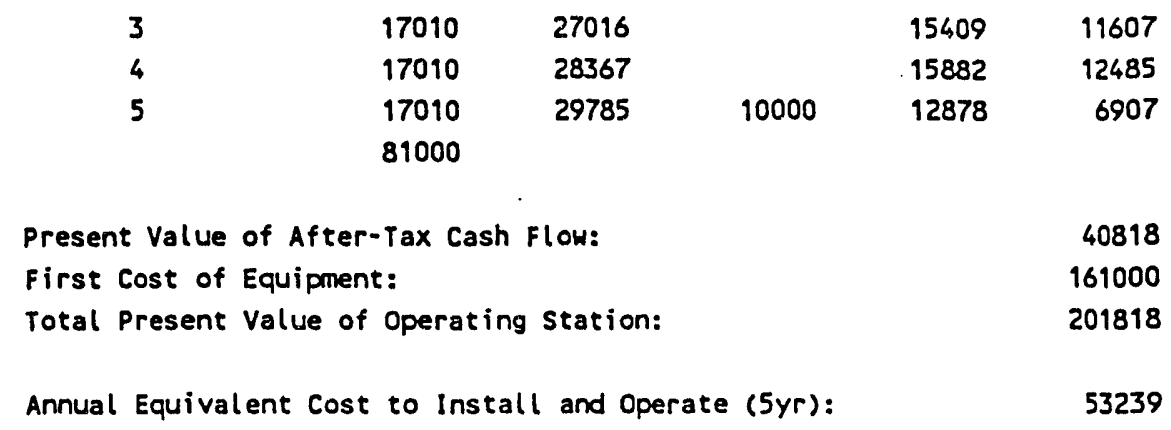

Annual Equivalent Cost for Sheet Cutting Station

\begin{tabular}{|c|c|c|c|c|c|c|}
\hline \multicolumn{2}{|c|}{ First Cost: } & 32500 & & & & \\
\hline \multicolumn{2}{|c|}{ Salvage: } & 2000 & & & & \multirow[b]{3}{*}{ ter-Tax } \\
\hline \multirow[t]{2}{*}{ Operating } & Cost: & 499 & & & & \\
\hline & \multicolumn{5}{|c|}{ Annual } & \\
\hline End & First & (ACRS) & Operating & & Tax & Cash \\
\hline Year & Cost & Deprec. & Expense & Salvage & Savings & Flow \\
\hline 0 & 32500 & & & & & \\
\hline 1 & & 3000 & 499 & & 1225 & -726 \\
\hline 2 & & 4400 & 524 & & 1723 & -1199 \\
\hline 3 & & 4200 & 550 & & 1663 & .1112 \\
\hline 4 & & 4200 & 578 & & 1672 & -1094 \\
\hline 5 & & 4200 & 607 & 2000 & 982 & -2376 \\
\hline & & 20000 & & & & \\
\hline
\end{tabular}

Present Value of After-Tax Cash Flow: $\quad-4709$

First Cost of Equipment: $\quad 32500$

Total Present Value of Operating Station: 27791

Annual Equivalent Cost to Install and Operate (5yr): $\quad 7331$

Annual Equivalent Cost: for Sheet Punching Station

First Cost: $\quad 12500$

Salvage: 0

Operating Cost: $\quad 499$

$\begin{array}{rrrrrrr}\text { End } & \text { First } & \begin{array}{c}\text { (ACRS) } \\ \text { Year }\end{array} & \begin{array}{c}\text { Annual } \\ \text { Opert } \\ \text { Deprec. }\end{array} & \begin{array}{c}\text { Expense } \\ \text { Exting }\end{array} & \begin{array}{c}\text { After-Tax } \\ \text { Salvage } \\ \text { Savings }\end{array} & \begin{array}{c}\text { Cash } \\ \text { Flow }\end{array} \\ 1 & 12500 & & & & 175 & 324 \\ 2 & & 0 & 499 & 183 & 341 \\ 3 & 0 & 524 & 193 & 358 \\ 4 & 0 & 550 & & 202 & 376 \\ 5 & & 0 & 578 & & 212 & 394\end{array}$

Present Value of After-Tax Cash Flow: 
First Cost of Equipment:

Annual Equivalent cost for Laser Scribing Station

$\begin{array}{lr}\text { First Cost: } & 228000 \\ \text { Salvage: } & 25000 \\ \text { Operating Cost: } & 54850\end{array}$

\begin{tabular}{|c|c|c|c|c|c|c|}
\hline \multirow{3}{*}{$\begin{array}{l}\text { End } \\
\text { Year }\end{array}$} & \multicolumn{4}{|c|}{ Annual } & \multicolumn{2}{|c|}{ After-Tax } \\
\hline & First & (ACRS) & Operating & & $\operatorname{Tax}$ & Cash \\
\hline & Cost & Deprec. & Expense & Salvage & Savings & Flow \\
\hline 0 & 228000 & & & & & \\
\hline 1 & & 16200 & 54850 & & 24867 & 29982 \\
\hline 2 & & 23760 & 57592 & & 28473 & 29119 \\
\hline 3 & & 22680 & 60472 & & 29103 & 31369 \\
\hline 4 & & 22680 & 63495 & & 30161 & 33334 \\
\hline 5 & & 22680 & 66670 & 25000 & 22523 & 19148 \\
\hline & & 108000 & & & & \\
\hline
\end{tabular}

Present Value of After-Tax Cash Flow:

Total Present Value of Operating Station:

Annual Equivalent Cost for Screen Printing Station

\begin{tabular}{|c|c|c|c|c|c|c|}
\hline \multicolumn{2}{|c|}{ First Cost: } & 86000 & & & & \\
\hline \multicolumn{2}{|c|}{ Salvage: } & 8000 & & & & \\
\hline \multirow[t]{2}{*}{ Operating } & Cost: & 45490 & & & & \\
\hline & & & Annual & & & ter-Tax \\
\hline \multirow{3}{*}{$\begin{array}{l}\text { End } \\
\text { Year } \\
0\end{array}$} & First & (ACRS) & Operating & & $\operatorname{Tax}$ & Cash \\
\hline & Cost & Deprec. & Expense & Salvage & Savings & Flow \\
\hline & 86000 & & & & & \\
\hline 1 & & 6900 & 45490 & & 18336 & 27153 \\
\hline 2 & & 10120 & 47764 & & 20259 & 27505 \\
\hline .3 & & 9660 & 50152 & & 20934 & 29218 \\
\hline 4 & & 9660 & 52660 & & 21812 & 30848 \\
\hline 5 & & 9660 & 55293 & 8000 & 19934 & 27359 \\
\hline & & 46000 & & & & \\
\hline
\end{tabular}

Present Value of After-Tax Cash Flow: $\quad 107425$

First Cost of Equipment:

Total Present Value of Operating Station:

193425

Annual Equivalent cost to Install and Operate (5yr):

51025 
Annual Equivalent Cost for Bus Bar Attachment Station

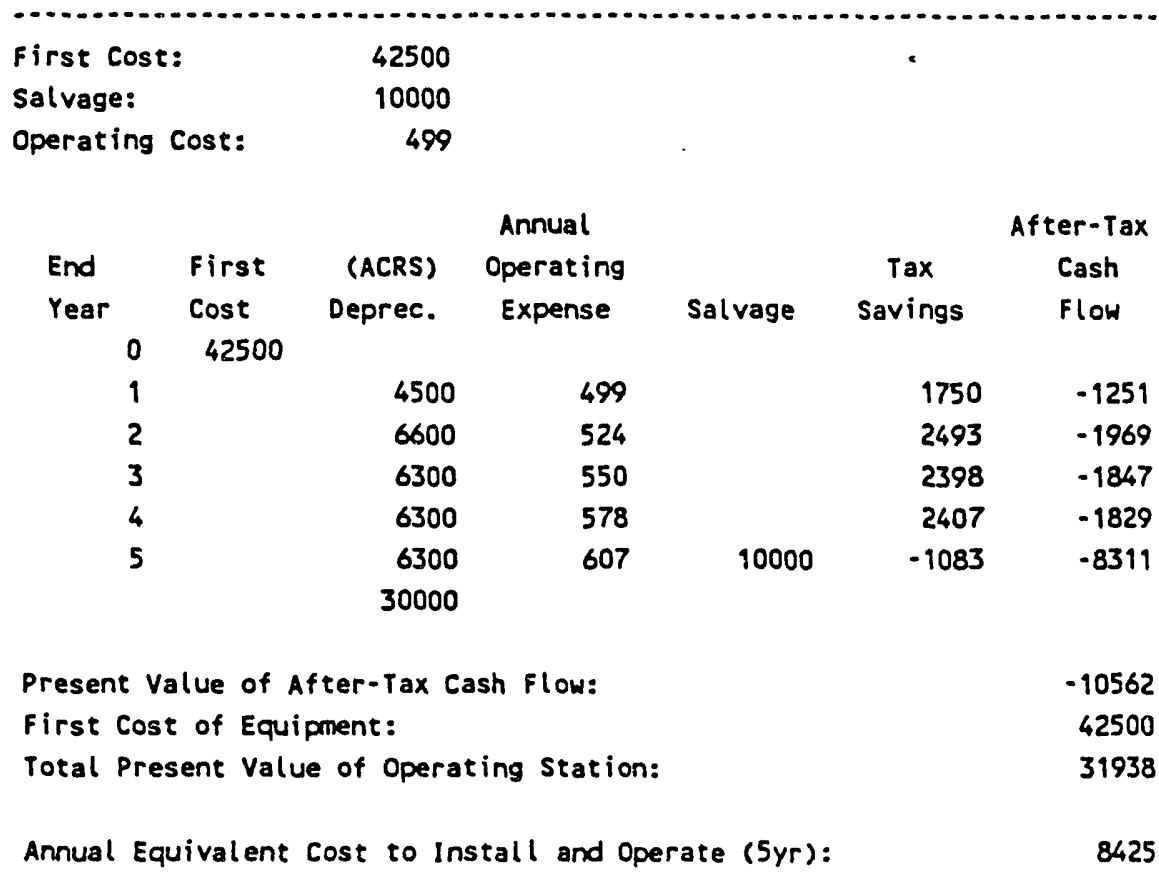

Annual Equivalent Cost for Encapsulation Station

First Cost: $\quad 18500$

Salvage: 0

Operating Cost: $\quad \mathbf{8 4 3 9 0}$

\begin{tabular}{|c|c|c|c|c|c|c|}
\hline \multirow{3}{*}{$\begin{array}{l}\text { End } \\
\text { Year }\end{array}$} & \multicolumn{4}{|c|}{ Annual } & \multicolumn{2}{|c|}{ After-Tax } \\
\hline & First & (ACRS) & Operating & & $\operatorname{Tax}$ & Cash \\
\hline & Cost & Deprec. & Expense & Salvage & Savings & flow \\
\hline 0 & 18500 & & & & & \\
\hline 1 & & 900 & 84390 & & 29851 & 54538 \\
\hline 2 & & 1320 & 88609 & & 31475 & 57134 \\
\hline 3 & & 1260 & 93040 & & 33005 & 60035 \\
\hline 4 & & 1260 & 97692 & & 34633 & 63059 \\
\hline 5 & & 9260 & 102576 & 0 & 36343 & 6623 \\
\hline & & 6000 & & & & \\
\hline
\end{tabular}

Present Value of After-Tax Cash Flow:

226099

First Cost of Equipment:

18500

Total Present Value of Operating Station:

244599

Annual Equivalent Cost to Install and Operate (5yr): 
Name of Scenario Being Evaluated: SCENARIO 4 A PIECE PROCESSING

Yield per Roll Produced (\# of modules 2400

Average Watts per Module:

Tax Rate: $\quad 0.35$

Interest Rate: $\quad 0.10$

Labor Rate per/hr for line supervisor 17.00

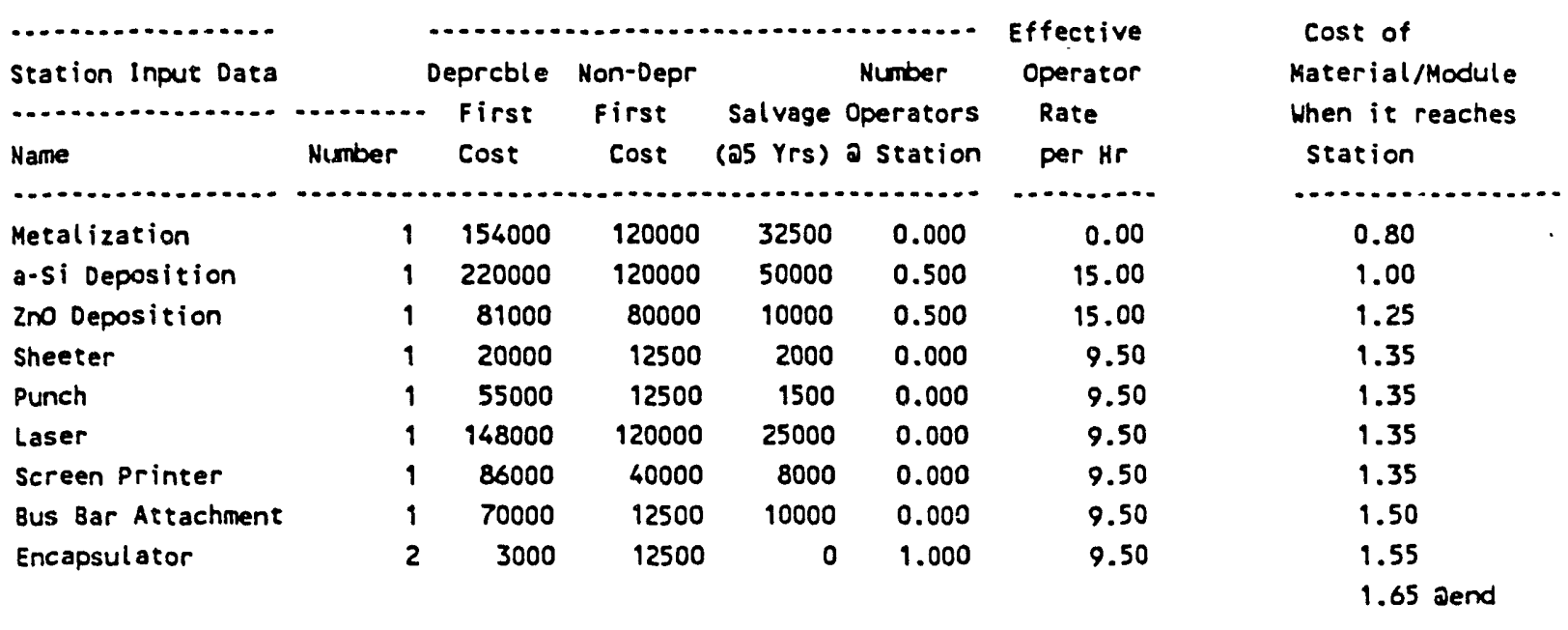

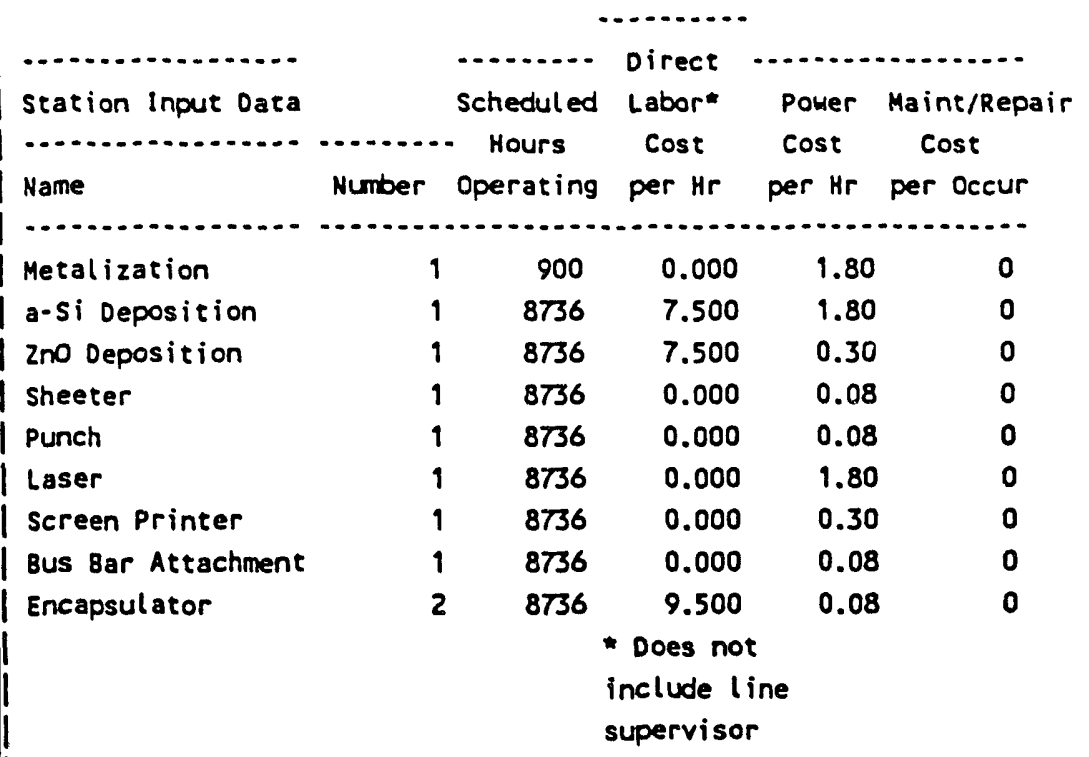




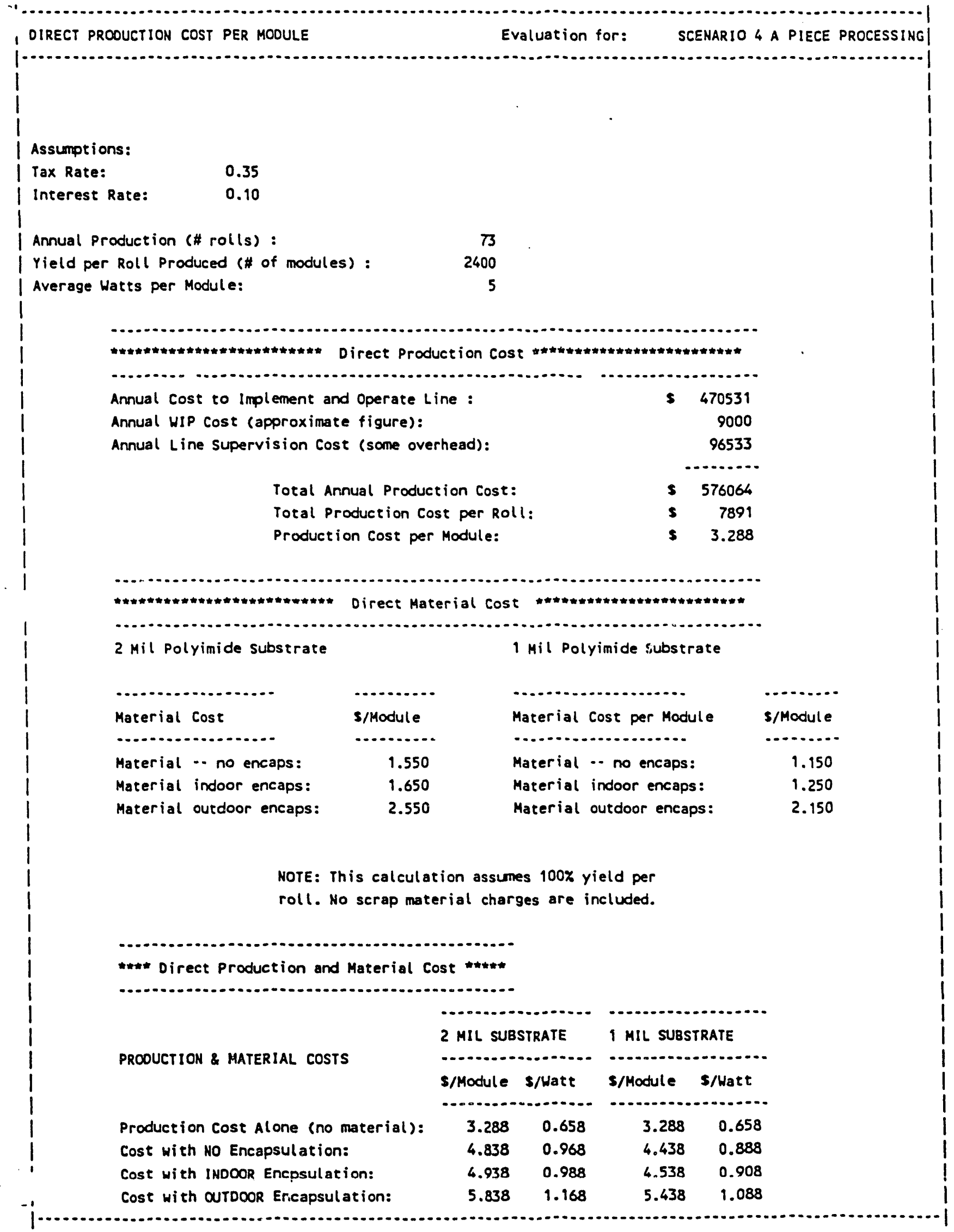




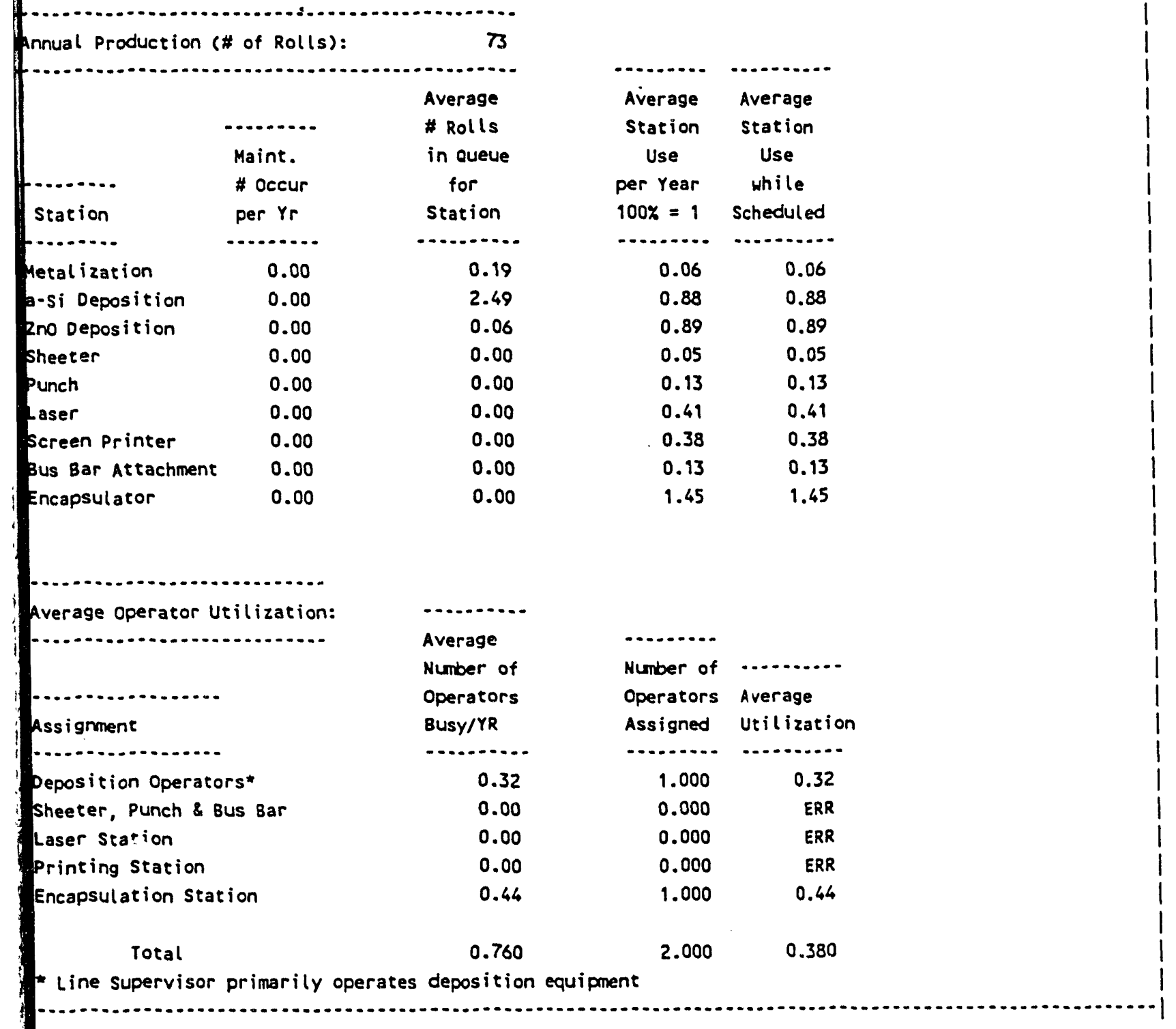




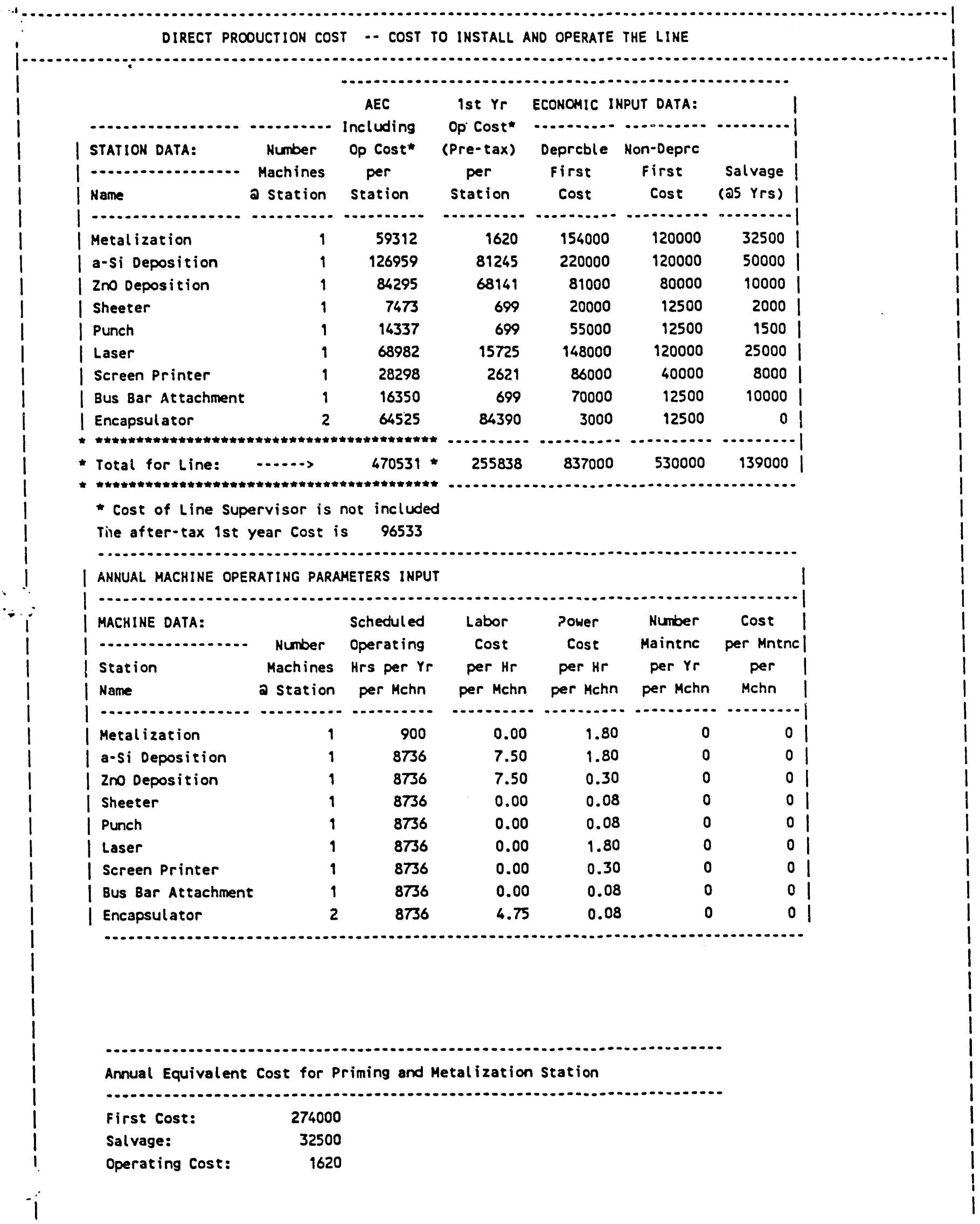




\begin{tabular}{rlrrrrr} 
End & First & $\begin{array}{r}\text { Annual } \\
\text { (ACRS) } \\
\text { Year }\end{array} \begin{array}{l}\text { Cost } \\
\text { Deprec. }\end{array}$ & $\begin{array}{c}\text { Aperating } \\
\text { Expense }\end{array}$ & Salvage & $\begin{array}{c}\text { Tax } \\
\text { Savings }\end{array}$ & $\begin{array}{c}\text { After-Tax } \\
\text { Cash } \\
\text { Flow }\end{array}$ \\
\hline & 274000 & & & & & \\
1 & & 23100 & 1620 & & 8652 & -7032 \\
2 & 33880 & 1701 & & 12453 & -10752 \\
3 & 32340 & 1786 & & 11944 & -10158 \\
4 & 32340 & 1875 & & 11975 & -10100 \\
5 & 32340 & 1969 & 32500 & 633 & -31164 \\
& & 154000 & & & &
\end{tabular}

Present Value of After-Tax Cash Flow:

Total Present Value of Equipment:

224840

Annual Equivalent Cost to Install and Operate (5yr):

59312

Annual Equivalent Cost for a-si Deposition Station

$\begin{array}{lr}\text { First Cost: } & 340000 \\ \text { Salvage: } & 50000 \\ \text { Operating Cost: } & 81245\end{array}$

$\begin{array}{rlrrrrr}\text { End } & \begin{array}{l}\text { First } \\ \text { Year }\end{array} & \begin{array}{c}\text { Cost } \\ \text { (ACRS) } \\ \text { Deprec. }\end{array} & \begin{array}{c}\text { Annul } \\ \text { Operating } \\ \text { Expense }\end{array} & \text { Salvage } & \begin{array}{c}\text { Tax } \\ \text { Savings }\end{array} & \begin{array}{c}\text { After-Tax } \\ \text { Cash } \\ \text { Flow }\end{array} \\ 1 & 340000 & & & & 39986 & 41259 \\ 1 & & 33000 & 81245 & & 46797 & 38510 \\ 2 & 48400 & 85307 & & 47520 & 42052 \\ 3 & 46200 & 89572 & & 49088 & 44963 \\ 4 & 46200 & 94051 & & 33234 & 15520 \\ 5 & 46200 & 98754 & 50000 & & \end{array}$

Present Yalue of After-Tax Cash Flow:

First cost of Equipment:

Total Present Value of Equipment:

481276

Annual Equivalent Cost to Install and Operate (5yr):

126959

Annual Equivalent Cost for Zno (top contact coating) Deposition Station

$\begin{array}{lr}\text { First Cost: } & 161000 \\ \text { Salvage: } & 10000 \\ \text { Operating Cost: } & 68149\end{array}$

\begin{tabular}{|c|c|c|c|c|c|c|}
\hline \multirow{3}{*}{$\begin{array}{l}\text { End } \\
\text { Year }\end{array}$} & \multicolumn{4}{|c|}{ Annual } & \multicolumn{2}{|c|}{ After-Tax } \\
\hline & First & (ACRS) & Operating & & $\operatorname{Tax}$ & Cash \\
\hline & Cost & Deprec. & Expense & Saivage & Savings & Flow \\
\hline 0 & 161000 & & & & & \\
\hline 1 & & 12150 & 68141 & & 28102 & 40039 \\
\hline 2 & & 17820 & 71548 & & 31279 & 40269 \\
\hline
\end{tabular}




$\begin{array}{llllll}3 & 17010 & 75125 & & 32247 & 42878 \\ 4 & 17010 & 78881 & & 33562 & 45319 \\ 5 & 17010 & 82826 & 10000 & 31442 & 41383 \\ & 81000 & & & & \end{array}$

Present Value of After-Tax Cash Flow: $\quad 158544$

First Cost of Equipment: $\quad 161000$

Total Present Value of Uperating Station: 319544

Annual Equivalent Cost to Install and Operate (5yr): 84295

Annual Equivalent Cost for Sheet Cutting station

$\begin{array}{lr}\text { First Cost: } & 32500 \\ \text { Salvage: } & 2000 \\ \text { Operating Cost: } & 699\end{array}$

\begin{tabular}{|c|c|c|c|c|c|c|}
\hline \multirow{3}{*}{$\begin{array}{l}\text { End } \\
\text { Year }\end{array}$} & \multicolumn{4}{|c|}{ Annual } & \multicolumn{2}{|c|}{ After-Tax } \\
\hline & First & (ACRS) & Operating & & $\operatorname{Tax}$ & Cash \\
\hline & $\operatorname{Cos} t$ & Deprec. & Expense & Salvage & Savings & Flow \\
\hline 0 & 32500 & & & & & \\
\hline 1 & & 3000 & 699 & & 1295 & -596 \\
\hline 2 & & 4400 & 734 & & 1797 & -1063 \\
\hline 3 & & 4200 & 771 & & 1740 & -969 \\
\hline 4 & & 4200 & 809 & & 1753 & -944 \\
\hline 5 & & 4200 & 849 & 2000 & 1067 & -2218 \\
\hline & & 20000 & & . & & \\
\hline
\end{tabular}

Present Value of After-Tax Cash Flow: $\quad-4170$

First Cost of Equipment: $\quad 32500$

Total Present Value of Operating Station: 28330

Annual Equivalent Cost to Install and Operate (5yr): 7473

Annual Equivale: $t$ Cost for Sheet Punching Station

$\begin{array}{lr}\text { First Cost: } & 67500 \\ \text { Salvage: } & 1500 \\ \text { Operating Cost: } & 699\end{array}$

$\begin{array}{rrrrrrr}\text { End } & \text { First } & \begin{array}{c}\text { Annual } \\ \text { (ACRS) } \\ \text { Year }\end{array} \begin{array}{c}\text { Cost } \\ \text { Deprec. }\end{array} & \begin{array}{c}\text { Aperating } \\ \text { Expense }\end{array} & \text { Salvage } & \begin{array}{c}\text { After-Tax } \\ \text { Savings }\end{array} & \begin{array}{c}\text { Cash } \\ \text { Flow }\end{array} \\ 0 & 67500 & & & & 3132 & -2433 \\ 1 & & 8250 & 699 & & 4492 & -3758 \\ 2 & 12100 & 734 & & 4312 & -3542 \\ 3 & 11550 & 771 & & 4326 & -3517 \\ 4 & 11550 & 809 & & 3815 & -4465 \\ 5 & 11550 & 849 & 1500 & & \end{array}$

Prese: : Value of After-Tax Cash Flow:

$-13153$ 
First Cost of Equipment:

Total Present Value of Operating Station:

Annual Equivalent Cost to Install and Operate (5yr):

Annual Equivalent Cost for Laser Scribing Station

First Cost: $\quad 268000$

Salvage: $\quad 25000$

Cperating Cost: $\quad 15725$

\begin{tabular}{|c|c|c|c|c|c|c|}
\hline \multirow{3}{*}{$\begin{array}{l}\text { End } \\
\text { Year }\end{array}$} & \multicolumn{4}{|c|}{ Annual } & \multicolumn{2}{|c|}{ After-Tax } \\
\hline & First & (ACRS) & Operating & & Tax & Cash \\
\hline & Cost & Deprec. & Expense & Salvage & Savings & Flow \\
\hline 0 & 268000 & & & & & \\
\hline 1 & & 22200 & 15725 & & 13274 & 2451 \\
\hline 2 & & 32560 & 16511 & & 17175 & -664 \\
\hline 3 & & 31080 & 17337 & & 16946 & 391 \\
\hline 4 & & 31080 & 18203 & & 17249 & 954 \\
\hline 5 & & 31080 & 19114 & 25000 & 8818 & -14704 \\
\hline & & 148000 & & & & \\
\hline
\end{tabular}

Present Value of After-Tax Cash Flow: $\quad-6505$

First Cost of Equipment:

268000

Total Present Value of Operating Station:

261495

Annual Equivalent Cost to Install and Operate (5yr):

68982

Annual Equivalent Cost for Screen Printing Station

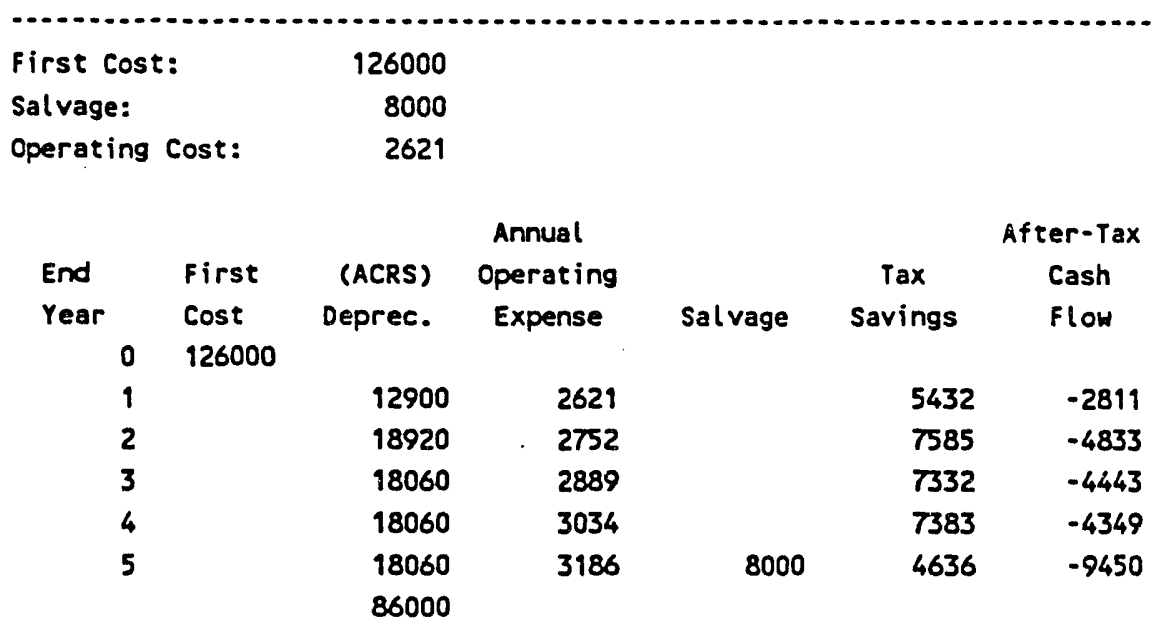

Present Value of After-Tax Cash Flow:

First Cost of Equipment:

126000

Total Present Value of Operating Station:

107273

Annual Equivalent cost to Install and Operate (5yr):

28298 
Annual Equivalent Cost for Bus Bar Attachment Station

$\begin{array}{lr}\text { First Cost: } & 82500 \\ \text { Salvage: } & 10000 \\ \text { Operating Cost: } & 699\end{array}$

$\begin{array}{rrrrrrr}\text { End } & \text { First } & \begin{array}{c}\text { Annual } \\ \text { (ACRS) } \\ \text { Year }\end{array} \begin{array}{ccccc}\text { Cost } \\ \text { Deprec. }\end{array} & \begin{array}{c}\text { Aperating } \\ \text { Expense }\end{array} & \text { Salvage } & \begin{array}{c}\text { After-Tax } \\ \text { Savings }\end{array} & \begin{array}{c}\text { Cash } \\ \text { Flow }\end{array} \\ 0 & 82500 & & & & 3920 & -3221 \\ 1 & & 10500 & 699 & & 5647 & -4913 \\ 2 & & 15400 & 734 & & 5415 & -4644 \\ 3 & & 14700 & 771 & & 5428 & -4619 \\ 4 & & 14700 & 809 & & 1942 & -11093 \\ 5 & & 14700 & 849 & 10000 & & \end{array}$

Present Value of After-Tax Cash Flow:

Total Present Value of Operating Station:

61980

Annual Equivalent Cost to Install and Operate (5yr):

$1 \in 3 ’ j 0$

Annual Equivalent cost for Encapsulation station

First Cost: 18500

Salvage: $\quad 0$

Operating Cost: $\quad 84390$

\begin{tabular}{|c|c|c|c|c|c|c|}
\hline \multirow{3}{*}{$\begin{array}{l}\text { End } \\
\text { Year }\end{array}$} & \multirow{3}{*}{$\begin{array}{l}\text { First } \\
\text { Cost }\end{array}$} & \multicolumn{3}{|c|}{ Annual } & \multicolumn{2}{|c|}{ After-Tax } \\
\hline & & (ACRS) & Operating & & $\operatorname{Tax}$ & Cash \\
\hline & & Deprec. & Expense & Salvage & Savings & Flow \\
\hline 0 & 18500 & & & & & \\
\hline 1 & & 900 & 84390 & & 29851 & 54538 \\
\hline 2 & & 1320 & 88609 & & 31475 & 57134 \\
\hline 3 & & 1260 & 93040 & & 33005 & 60035 \\
\hline 4 & & 9260 & 97692 & & 34633 & 63059 \\
\hline 5 & & 1260 & 102576 & 0 & 36343 & 66234 \\
\hline & & 6000 & & & & \\
\hline
\end{tabular}

Present Value of After-Tax Cash Flow:

226099

First Cost of Equipment:

18500

Total Present Value of Operating station:

244599

Annual Equivalent Cost to Install and Operate (5yr):

64525 
Name of Scenario Being Evaluated: SCENARIO 4 B PIECE PROCESSING

Yield per Roll Produced (\# of modules 2400

Average Watts per Module:

5

Tax Rate: $\quad 0.35$

Interest Rate: $\quad 0.10$

Labor Rate per/hr for line supervisor $\quad 17.00$

station input data

Station Input Data

Name

Metalization

a-si Deposition

2no Deposition

Sheeter

Punch

Laser

Screen Printer

Bus Bar Attachment

Encapsulator

Deprcble Non-Depr
First First S

Number

Cost (25 Yrs) a station

Effective

Operator

Rate

per $\mathrm{Hr}$

0.00

0.00

15.00

15.00

9.50

9.50

9.50

9.50

9.50

9.50
Cost of

Material/Module

When it reaches

station

0.80

1.00

1.25

1.35

1.35

1.35

1.35

1.50

1.55

1.65 aend

Station Input Data

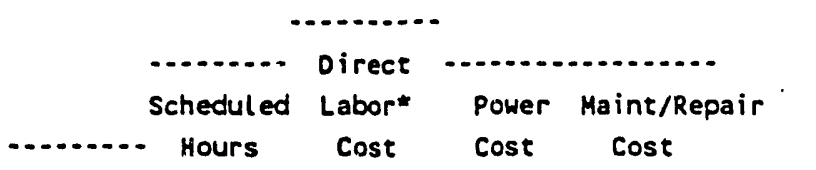

Name

Number Operating per $\mathrm{Hr}$ per $\mathrm{Hr}$ per Occur

.....................

Metalization

a-si Deposition

2no Deposition

Sheeter

Punch

Laser

Screen Printer

Bus Bar Attachment

Encapsulator

$\begin{array}{rrrr}900 & 0.000 & 1.80 & 0 \\ 8736 & 7.500 & 1.80 & 0 \\ 8736 & 7.500 & 0.30 & 0 \\ 4368 & 0.000 & 0.08 & 0 \\ 4368 & 0.000 & 0.08 & 0 \\ 4368 & 0.000 & 1.80 & 0 \\ 4368 & 0.000 & 0.30 & 0 \\ 4368 & 0.000 & 0.08 & 0 \\ 8736 & 9.500 & 0.08 & 0 \\ \text { * Does not } & & \\ \text { include line } & & \\ \text { supervisor } & \end{array}$




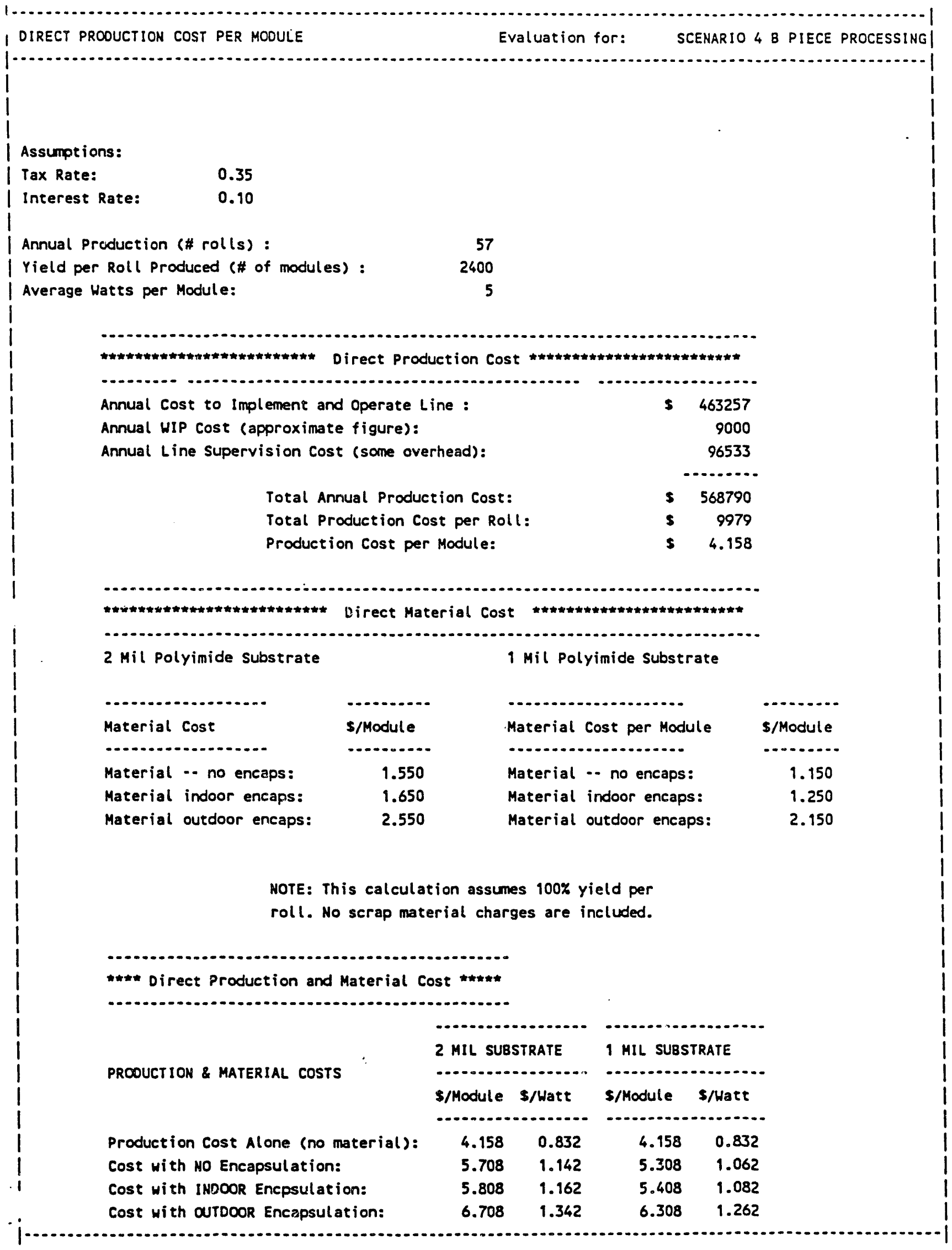




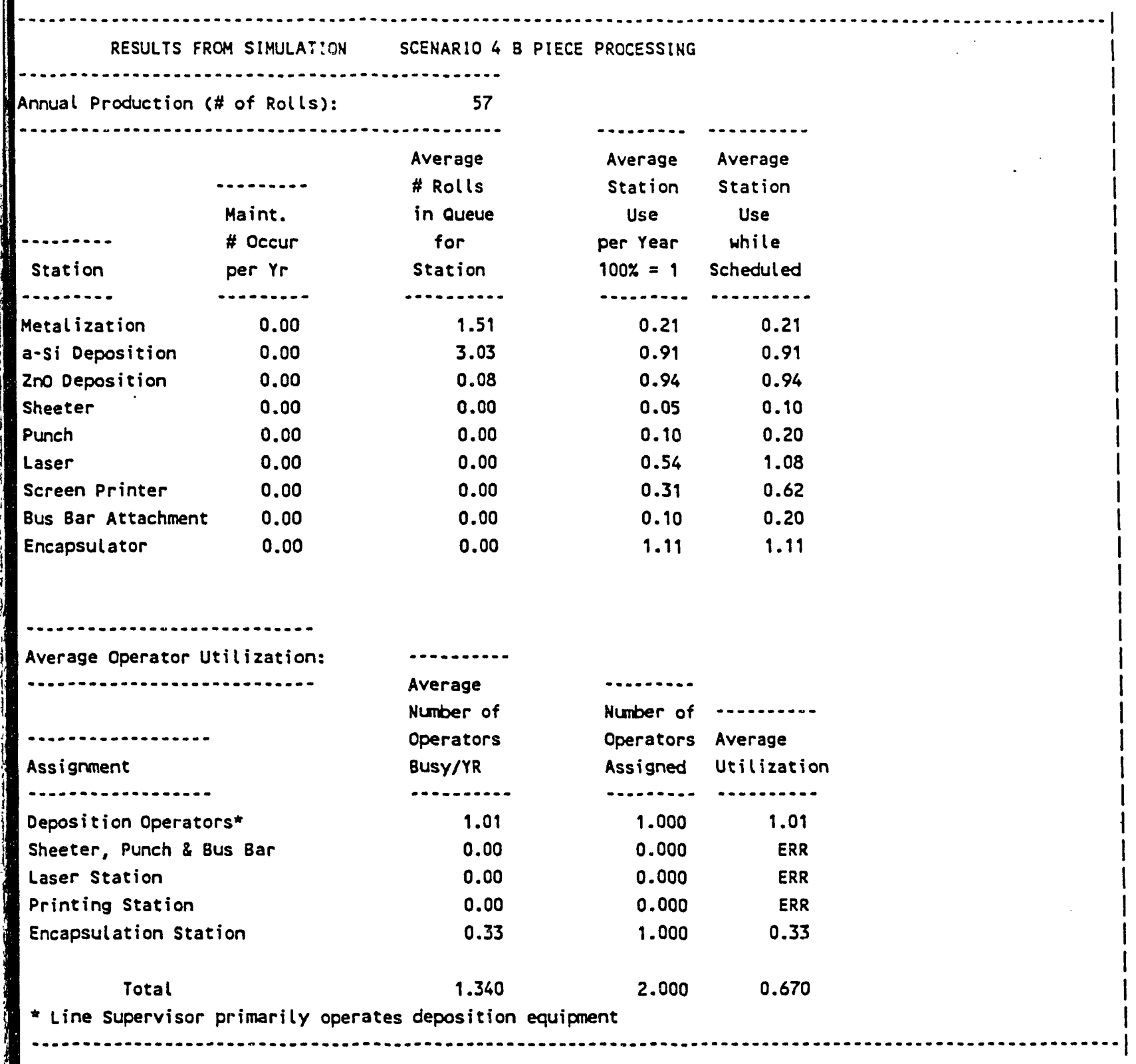




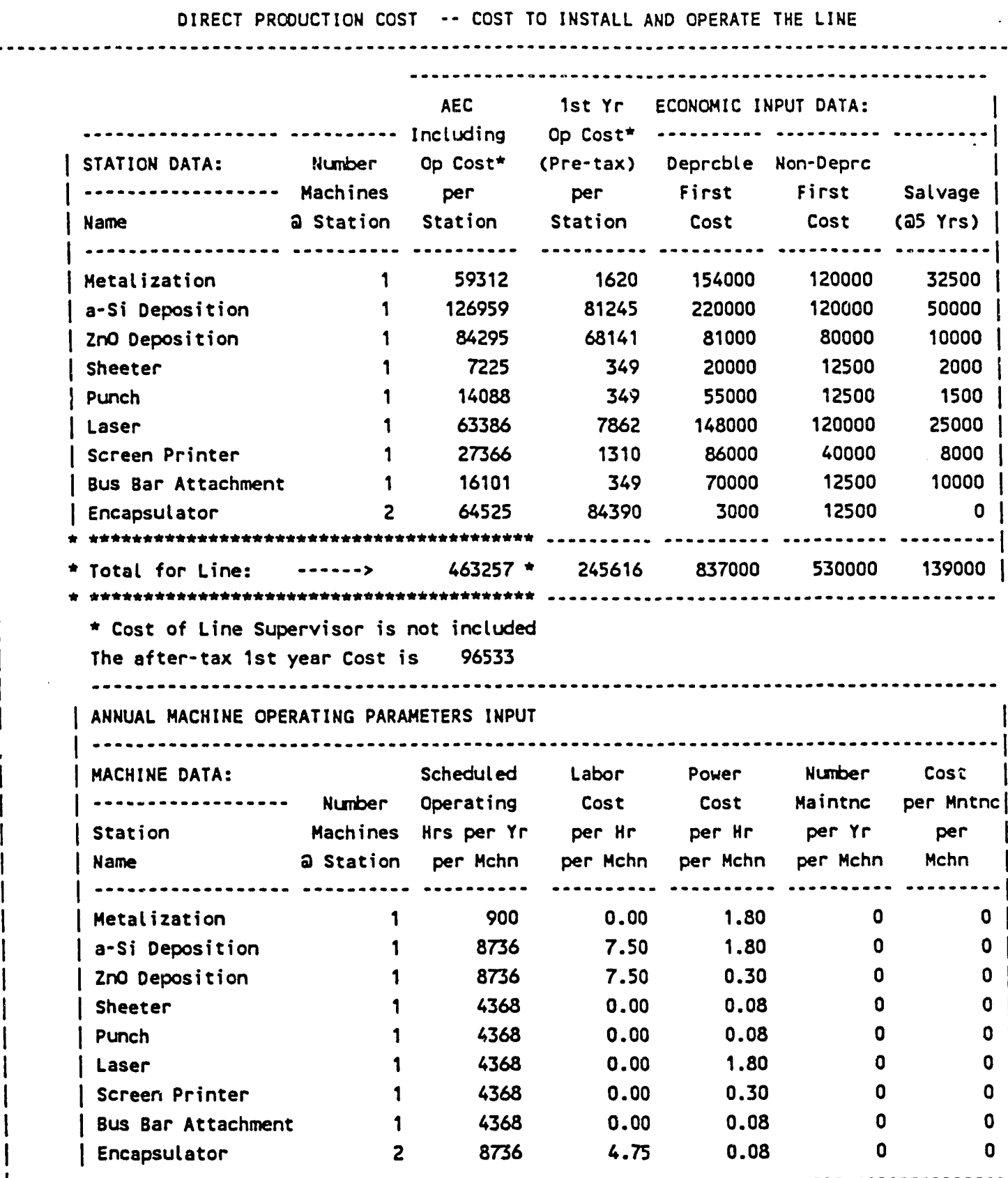

Annual Equivalent Cost for Priming and Metalization Station

$\begin{array}{lr}\text { First Cost: } & 274000 \\ \text { Salvage: } & 32500 \\ \text { Operating Cost: } & 1620\end{array}$




\begin{tabular}{|c|c|c|c|c|c|c|}
\hline \multirow{3}{*}{$\begin{array}{l}\text { End } \\
\text { Year }\end{array}$} & \multicolumn{4}{|c|}{ Annual } & \multicolumn{2}{|c|}{ After-Tax } \\
\hline & First & (ACRS) & Operating & & $\operatorname{Tax}$ & Cash \\
\hline & Cost & Deprec. & Expense & Salvage & Savings & Flow \\
\hline 0 & 274000 & & & & & \\
\hline 1 & & 23100 & 1620 & & 8652 & -7032 \\
\hline 2 & & 33880 & 1701 & & 12453 & -10752 \\
\hline 3 & & 32340 & 1786 & & 11944 & -10158 \\
\hline 4 & & 32340 & 1875 & & 11975 & -10100 \\
\hline 5 & & 32340 & 1969 & 32500 & 633 & -31164 \\
\hline & & 154000 & & & & \\
\hline
\end{tabular}

Present Value of After-Tax Cash Flow: $\quad-49160$

First Cost of Equipment: $\quad 274000$

$\begin{array}{ll}\text { Total Present Value of Equipment: } & 224840\end{array}$

Annual Equivalent Cost to Install and Operate (5yr): 59312

Annual Equivalent Cost for a-si Deposition Station

\begin{tabular}{|c|c|c|c|c|c|c|}
\hline \multicolumn{2}{|c|}{ First Cost: } & 340000 & & & & \\
\hline \multicolumn{2}{|c|}{ Salvage: } & 50000 & & & & \\
\hline \multirow[t]{2}{*}{ Operating } & Cost: & 81245 & & & & \\
\hline & & & Annual & & & ter-Tax \\
\hline \multirow{2}{*}{$\begin{array}{l}\text { End } \\
\text { Year }\end{array}$} & First & (ACRS) & Operating & & $\operatorname{Tax}$ & Cash \\
\hline & Cost & Deprec. & Expense & Salvage & Savings & Flow \\
\hline 0 & 340000 & & & & & \\
\hline 1 & & 33000 & 81245 & & 39986 & 41259 \\
\hline \multicolumn{2}{|l|}{2} & 48400 & 85307 & & 46797 & 38510 \\
\hline \multicolumn{2}{|l|}{3} & 46200 & 89572 & & 47520 & 42052 \\
\hline \multicolumn{2}{|l|}{4} & 46200 & 94051 & & 49088 & 44963 \\
\hline \multirow[t]{2}{*}{5} & & 46200 & 98754 & 50000 & 33234 & 15520 \\
\hline & & 220000 & & & & \\
\hline
\end{tabular}

$\begin{array}{ll}\text { Present Value of Aftzr-Tax Cash Flow: } & 141276\end{array}$

First Cost of Equipment: $\quad 340000$

$\begin{array}{ll}\text { Total Present Value of Equipment: } & 481276\end{array}$

Annual Equivalent Cost to Install and Operate (5yr): 126959

Annual Equivalent cost for 2 no (top contact coating) Deposition station

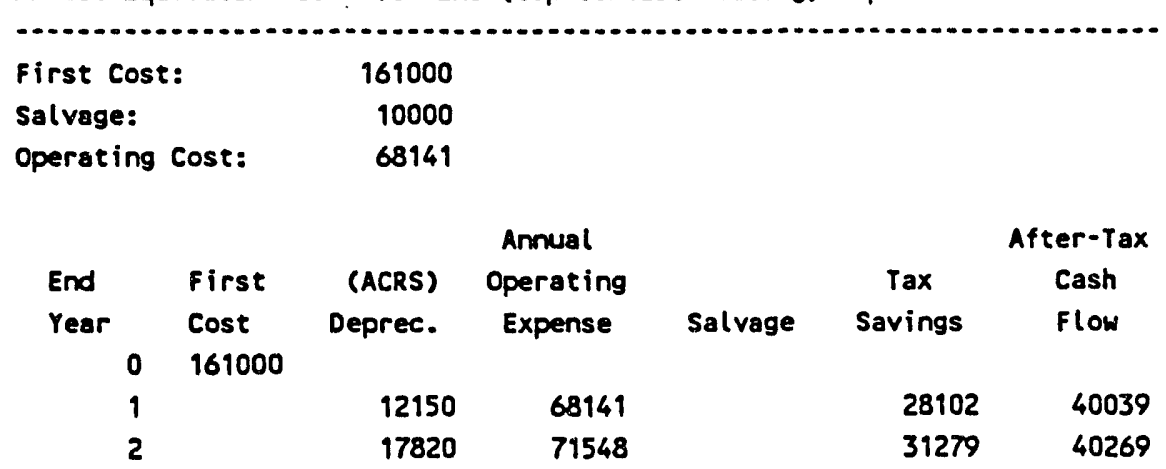




$\begin{array}{llllll}3 & 17010 & 75125 & & 32247 & 42878 \\ 4 & 17010 & 78881 & & 33562 & 45319 \\ 5 & 17010 & 82826 & 10000 & 31442 & 41383 \\ & 81000 & & & & \end{array}$

Present Value of After-Tax Cash Flow: 158544

$\begin{array}{ll}\text { First Cost of Equipment: } & 161000\end{array}$

Total Present Value of Operating Station: 319544

Annual Equivalent Cost to Install and Operate (5yr): 84295

Annual Equivalent Cost for Sheet Cutting station

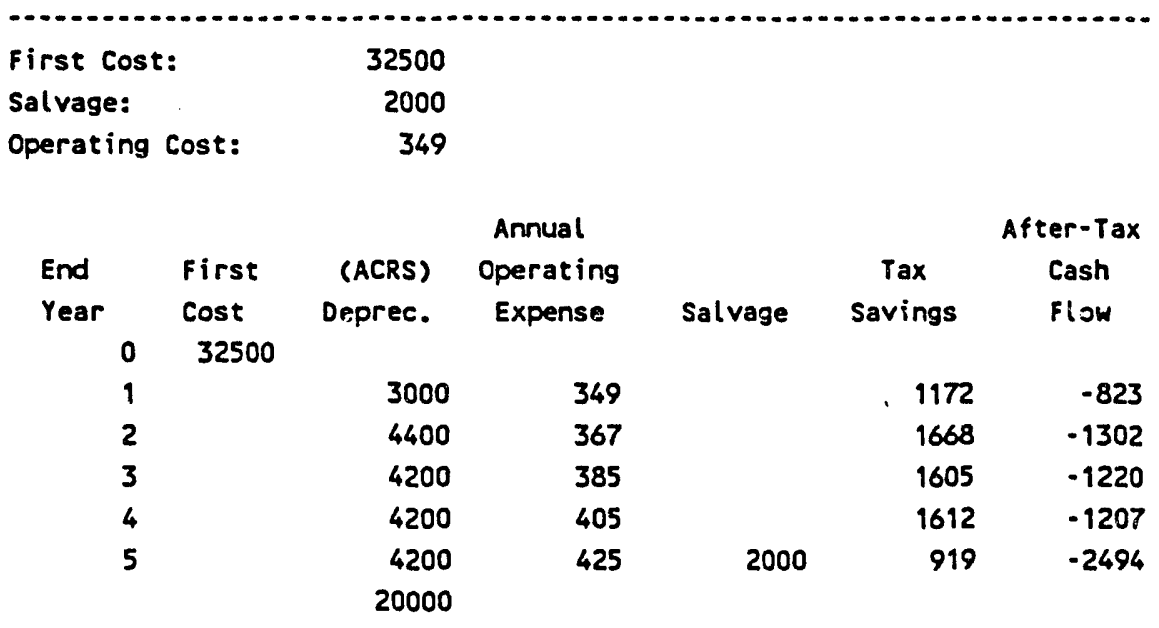

Present Value of After-Tax Cash Flow: $\quad-5113$

First Cost of Equipment: $\quad 32500$

$\begin{array}{ll}\text { Total Present Value of Operating Station: } & 27387\end{array}$

Annual Equivalent Cost to Install and Operate (5yr): 7225

Annual Equivalent Cost for Sheet Punching Station

$\begin{array}{lr}\text { First Cost: } & 67500 \\ \text { Salvage: } & 1500\end{array}$

$\begin{array}{lr}\text { Salvage: } & 1500 \\ \text { Operating Cost: } \quad 349\end{array}$

Operating Cost: 349

\begin{tabular}{|c|c|c|c|c|c|c|}
\hline \multirow{3}{*}{$\begin{array}{l}\text { End } \\
\text { Year }\end{array}$} & \multirow[b]{2}{*}{$\begin{array}{l}\text { First } \\
\text { Cost }\end{array}$} & \multirow{2}{*}{\multicolumn{2}{|c|}{$\begin{array}{l}\text { Annual } \\
\text { Operating } \\
\text { Expense }\end{array}$}} & \multirow{3}{*}{ Salvage } & \multicolumn{2}{|c|}{ After-Tax } \\
\hline & & & & & $\begin{array}{c}\text { Tax } \\
\text { Savings }\end{array}$ & $\begin{array}{l}\text { Cash } \\
\text { flow }\end{array}$ \\
\hline & 67500 & & & & & \\
\hline 1 & & 8250 & 349 & & 3010 & -2660 \\
\hline 2 & & 12100 & 367 & & 4363 & -3997 \\
\hline 3 & & 11550 & 385 & & 4177 & -3792 \\
\hline 4 & & 11550 & 405 & & 4184 & -3780 \\
\hline 5 & & 11550 & 425 & 1500 & 3666 & -4741 \\
\hline & & 55000 & & & & \\
\hline
\end{tabular}


First Cost of Equipment:

Total Present Value of Operating Station:

Annual Equivalent cost for Laser Scribing Station

$\begin{array}{lr}\text { First Cost: } & 268000 \\ \text { Salvage: } & 25000\end{array}$

Salvage:

Operating Cost: $\quad 7862$

\begin{tabular}{|c|c|c|c|c|c|c|}
\hline \multirow{3}{*}{$\begin{array}{l}\text { End } \\
\text { Year }\end{array}$} & \multicolumn{4}{|c|}{ Annual } & \multicolumn{2}{|c|}{ After-Tax } \\
\hline & First & (ACRS) & Operating & & Tax & Cash \\
\hline & Cost & Deprec. & Expense & Salvage & Savings & Flow \\
\hline 0 & 268000 & & & & & \\
\hline 1 & & 22200 & 7862 & & 10522 & -2659 \\
\hline 2 & & 32560 & 8256 & & 14285 & -6030 \\
\hline 3 & & 31080 & 8668 & & 13912 & -5244 \\
\hline 4 & & 31080 & 9102 & & 14064 & $-49 \% \cdot 2$ \\
\hline 5 & & 31080 & 9557 & 25000 & 5473 & $-20>16$ \\
\hline & & 148000 & & & & \\
\hline
\end{tabular}

Present Value of After-Tax Cash Flow:

First Cost of Equipment:

Total Present Value of Operating Station:

240283

Annual Equivalent Cost to Install and Operate (5yr):

63386

Annual Equivalent Cost for Screen Printing Station

First Cost: 126000

Salvage: $\quad 8000$

Operating Cost: $\quad 1310$

\begin{tabular}{|c|c|c|c|c|c|c|}
\hline \multirow{3}{*}{$\begin{array}{l}\text { End } \\
\text { Year }\end{array}$} & \multicolumn{4}{|c|}{ Annual } & \multicolumn{2}{|c|}{ After-Tax } \\
\hline & First & (ACRS) & Operating & & $\operatorname{Tax}$ & Cash \\
\hline & Cost & Deprec. & Expense & Salvage & Savings & Flow \\
\hline 0 & 126000 & & & & & \\
\hline 1 & & 12900 & 1310 & & 4974 & -3663 \\
\hline 2 & & 18920 & 1376 & & 7104 & -5728 \\
\hline 3 & & 18060 & 1445 & & 6827 & -5382 \\
\hline 4 & & 18060 & 1517 & & 6852 & -5335 \\
\hline 5 & & 18060 & 1593 & 8000 & 4078 & -10486 \\
\hline & & 86000 & & & & \\
\hline
\end{tabular}

Present Value of After-Tax Cash flow:

First Cost of Equipment:

126000

Total Present Value of Operating station:

103738

Annual Equivalent Cost to Install and Operate (5yr): 27366 
Annual Equivalent Cost for Bus Bar Attachment Station

$\begin{array}{lr}\text { First Cost: } & 82500 \\ \text { Salvage: } & 10000 \\ \text { Operating Cost: } & 349\end{array}$

Operating Cost: $\quad 349$

$\begin{array}{rrrrrrr}\text { End } & \text { First } & \begin{array}{c}\text { Annual } \\ \text { (ACRS) } \\ \text { Year }\end{array} \begin{array}{c}\text { Cost } \\ \text { Deprec. }\end{array} & \begin{array}{c}\text { Operating } \\ \text { Expense }\end{array} & \text { Salvage } & \begin{array}{c}\text { Tax } \\ \text { Savings }\end{array} & \begin{array}{c}\text { After-Tax } \\ \text { Cash } \\ \text { Flow }\end{array} \\ 0 & 82500 & & & & & \\ 1 & & 10500 & 349 & & 3797 & -3448 \\ 2 & & 15400 & 367 & & 5518 & -5152 \\ 3 & 14700 & 385 & & 5280 & -4895 \\ 4 & 14700 & 405 & & 5287 & -4882 \\ 5 & & 14700 & 425 & 10000 & 1794 & -11369 \\ & 70000 & & & & \end{array}$

Present Value of After-Tax Cash Flow:

First Cost of Equipment:

82500

Total Present Value of Operating station:

61037

Annual Equivalent Cost to Install and Operate (5yr):

16101

Annual Equivalent Cost for Encapsulation Station

\begin{tabular}{|c|c|c|c|c|c|c|}
\hline \multicolumn{2}{|c|}{ First Cost: } & 18500 & & & & \\
\hline \multicolumn{2}{|l|}{ Salvage: } & 0 & & & & \\
\hline \multirow[t]{2}{*}{ Operating } & Cost: & 84390 & & & & \\
\hline & & & Annual & & & ter-Tax \\
\hline \multirow{9}{*}{$\begin{array}{l}\text { End } \\
\text { Year }\end{array}$} & First & (ACRS) & Operating & & $\operatorname{Tax}$ & Cash \\
\hline & Cost & Deprec. & Expense & Salvage & Savings & FlOH \\
\hline & 18500 & & & & & \\
\hline & & 900 & 84390 & & 29851 & 54538 \\
\hline & & 1320 & 88609 & & 31475 & 57134 \\
\hline & & 1260 & 93040 & & 33005 & 60035 \\
\hline & & 1260 & 97692 & & 34633 & 63059 \\
\hline & & 1260 & 102576 & 0 & 36343 & 66234 \\
\hline & & 6000 & & & & \\
\hline
\end{tabular}

Present Value of After-Tax Cash Flow:

226099

18500

First Cost of Equipment:

244599

Annual Equivalent Cost to Install and Operate (5yr):

64525 


\section{SCENARIO $4 \mathrm{C}$}

WNPUT DATA REQUIRED FOR ANALYSIS DATE EVALUATED: 3/27/91

Jame of Scenario Being Evaluated: SCENARIO 4 C PIECE PROCESSING

rield per Roll Produced (\# of mojules 2400

Average Watts per Module:

Tax Rate:

0.35

Interest Rate:

0.10

abor Rate per/hr for line supervisor

17.00

Station Input Data

Name

-

Metalization

a-si Deposition

Zno Deposition

Sheeter

Punch

Laser

Screen Printer

Bus Bar Attachment

Encapsulator

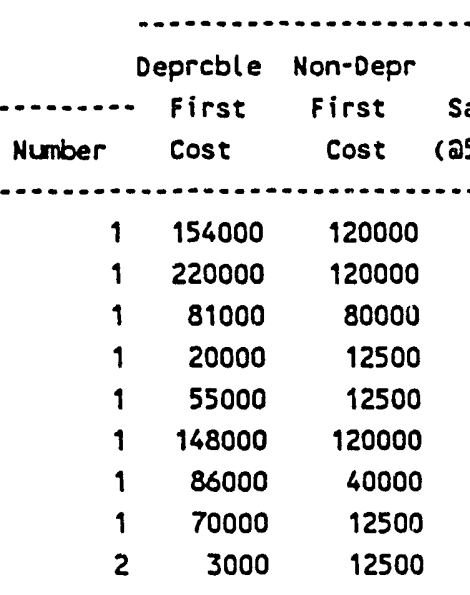

Number

Salvage Operators

a5 Yrs) a station

32500

50000

10000

2000

1500

2.5000

8000

10000

0

\begin{tabular}{|c|c|}
\hline $\begin{array}{l}\text { umber } \\
\text { erators } \\
\text { station }\end{array}$ & $\begin{array}{c}\text { Effective } \\
\text { Operator } \\
\text { Rate } \\
\text { per } \mathrm{Hr}\end{array}$ \\
\hline -.... & 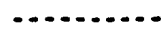 \\
\hline 0.000 & 0.00 \\
\hline 0.500 & 15.00 \\
\hline 0.500 & 15.00 \\
\hline 0.000 & 9.50 \\
\hline 0.000 & 9.50 \\
\hline 0.000 & 9.50 \\
\hline 0.000 & 9.50 \\
\hline 0.000 & 9.50 \\
\hline $1.00 n$ & 9.50 \\
\hline
\end{tabular}

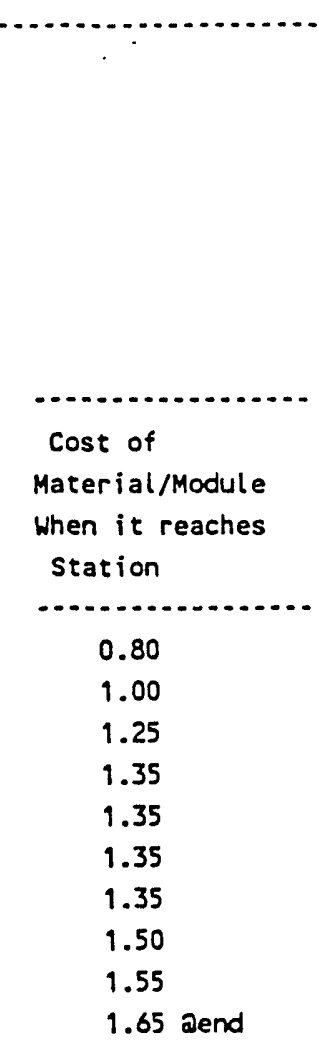

\section{Cost of}

Material/Module

When it reaches

Station

0.80

1.35

1.35

1.35

1.35

1.55

1.65 aend 


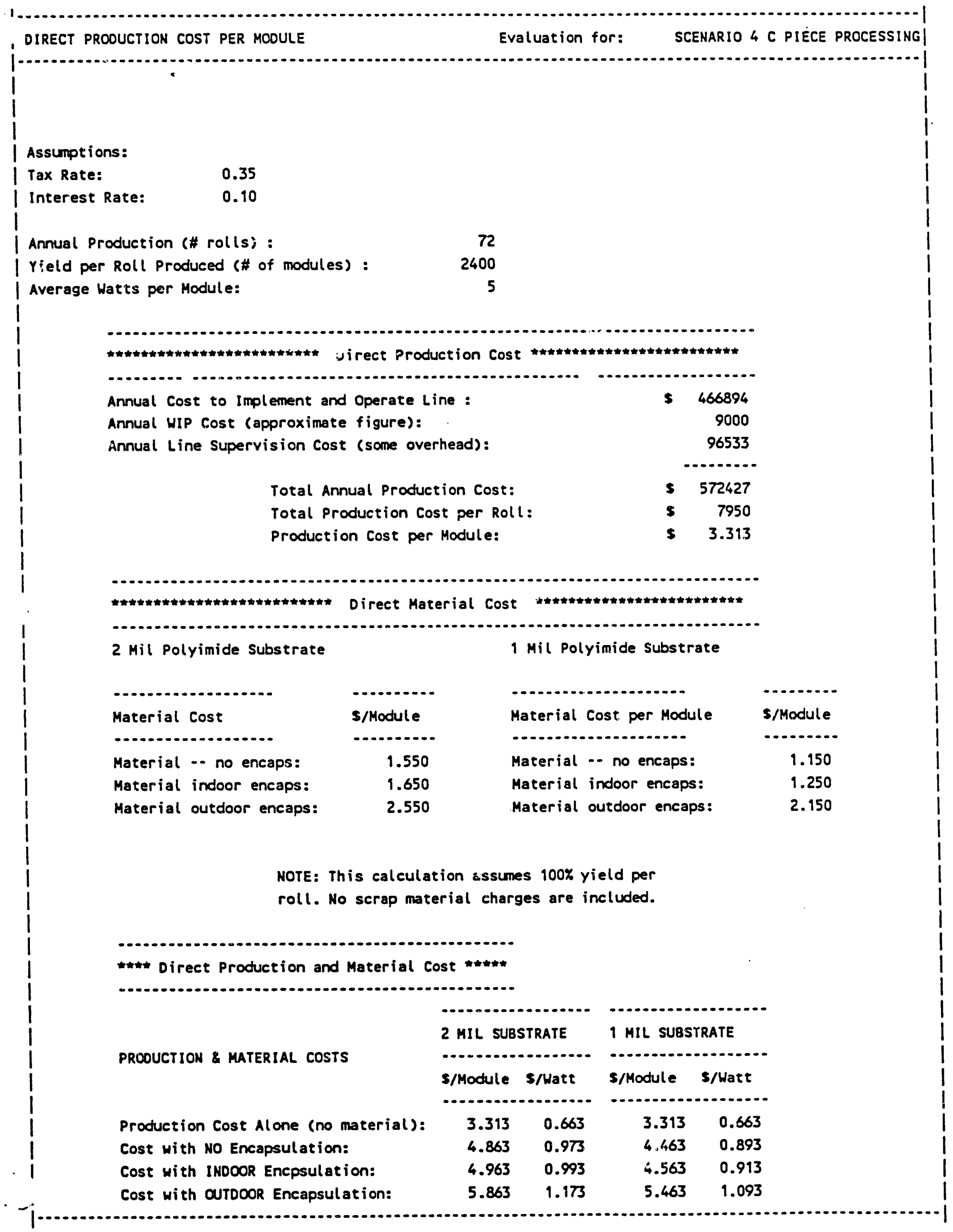


n................

Station

-..........

Metalization

a-Si Deposition

2no Deposition

Sheeter

Punch

Laser

Screen Printer

Bus Bar Attachment

tncapsulator

Maint.
\# Occur
per Yr
0.00
0.00
0.00
0.00
0.00
0.00
0.00
0.00
0.00

Average Operator Utilization:

.................................

\section{Assignment}

Deposition Operators*

Sheeter, Punch \& Bus Bar

Laser Station

Printing station

Encapsulation station

Average
\# Rolls
in Queue
for
station
0.19
2.51
0.06
0.00
0.00
0.00
0.00
0.00
0.00

$\cdots$

\section{Average}

Number of

Oper itors

BUSY/YR

-..........

0.41

0.00

0.00

0.00

0.43

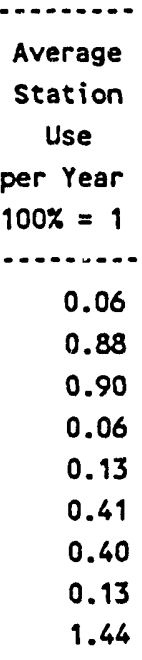

Average

Station

Use

while

Scheduled

0.06

0.88

0.90

0.08

0.17

0.55

0.53

0.17

1.44

Total

0.840

Number of

Operators

Assigned

Average

Utilization

1.000

...........

0.41

0.000

ERR

0.000

ERR

0.000

ERR

1.000

0.43

2.000

0.420

- Line Supervisor primarily operates deposition equipment 


\begin{tabular}{|c|c|c|c|c|c|c|}
\hline \multirow{3}{*}{$\begin{array}{l}\text { End } \\
\text { Year }\end{array}$} & \multicolumn{4}{|c|}{ Annual } & \multicolumn{2}{|c|}{ After-Tax } \\
\hline & First & (ACRS) & Operating & & $\operatorname{Tax}$ & Cash \\
\hline & Cost & Deprec. & Expense & Salvage & Savings & Flow \\
\hline 0 & 274000 & & & & & \\
\hline 1 & & 23100 & 1620 & & 8652 & -7032 \\
\hline 2 & & 33880 & 1701 & & 12453 & -10752 \\
\hline 3 & & 32340 & 1786 & & 11944 & -10158 \\
\hline 4 & & 32340 & 1873 & & 11975 & -10100 \\
\hline 5 & & 32340 & 1969 & 32500 & 633 & -31164 \\
\hline & & 154000 & & & & \\
\hline
\end{tabular}

Present Value of After-Tax Cash Flow:

First Cost of Equipment:

224840

Annual Equivalent Cost to Install and Operate (5yr):

59312

Annual Equivalent Cost for a-Si Deposition Station

$\begin{array}{lr}\text { First Cost: } & 340000 \\ \text { Salvage: } & 50000 \\ \text { Operating Cost: } & 81245\end{array}$

Operating Cost: $\quad 81245$

\begin{tabular}{|c|c|c|c|c|c|c|}
\hline \multirow{3}{*}{$\begin{array}{l}\text { End } \\
\text { Year }\end{array}$} & \multicolumn{4}{|c|}{ Annual } & \multicolumn{2}{|c|}{ After-Tax } \\
\hline & First & (ACRS) & Operating & & $\operatorname{Tax}$ & Cash \\
\hline & Cost & Deprec. & Expense & Salvage & Savings & Flow \\
\hline 0 & 340000 & & & & & \\
\hline 1 & & 33000 & 81245 & & 39986 & 41259 \\
\hline 2 & & 48400 & 85307 & & 46797 & 38510 \\
\hline 3 & & 46200 & 89572 & & 47520 & 42052 \\
\hline 4 & & 46200 & 94051 & & 49088 & 44963 \\
\hline 5 & & 46200 & 98754 & 50000 & 33234 & 15520 \\
\hline & & 220000 & & & & \\
\hline
\end{tabular}

Present Value of After-Tax Cash Flow:

141276

First Cost of Equipment:

340000

Total Present Value of Equipment:

481276

Annual Equivalent Cost to Install and Operate (5yr):

126959

Annual Equivalent Cost for 2no (top contact coating) Deposition Station

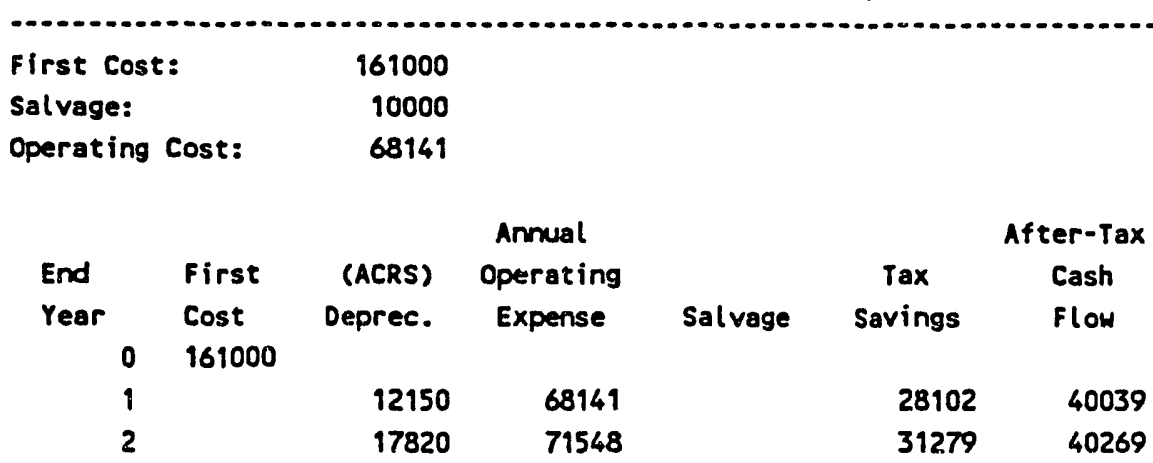




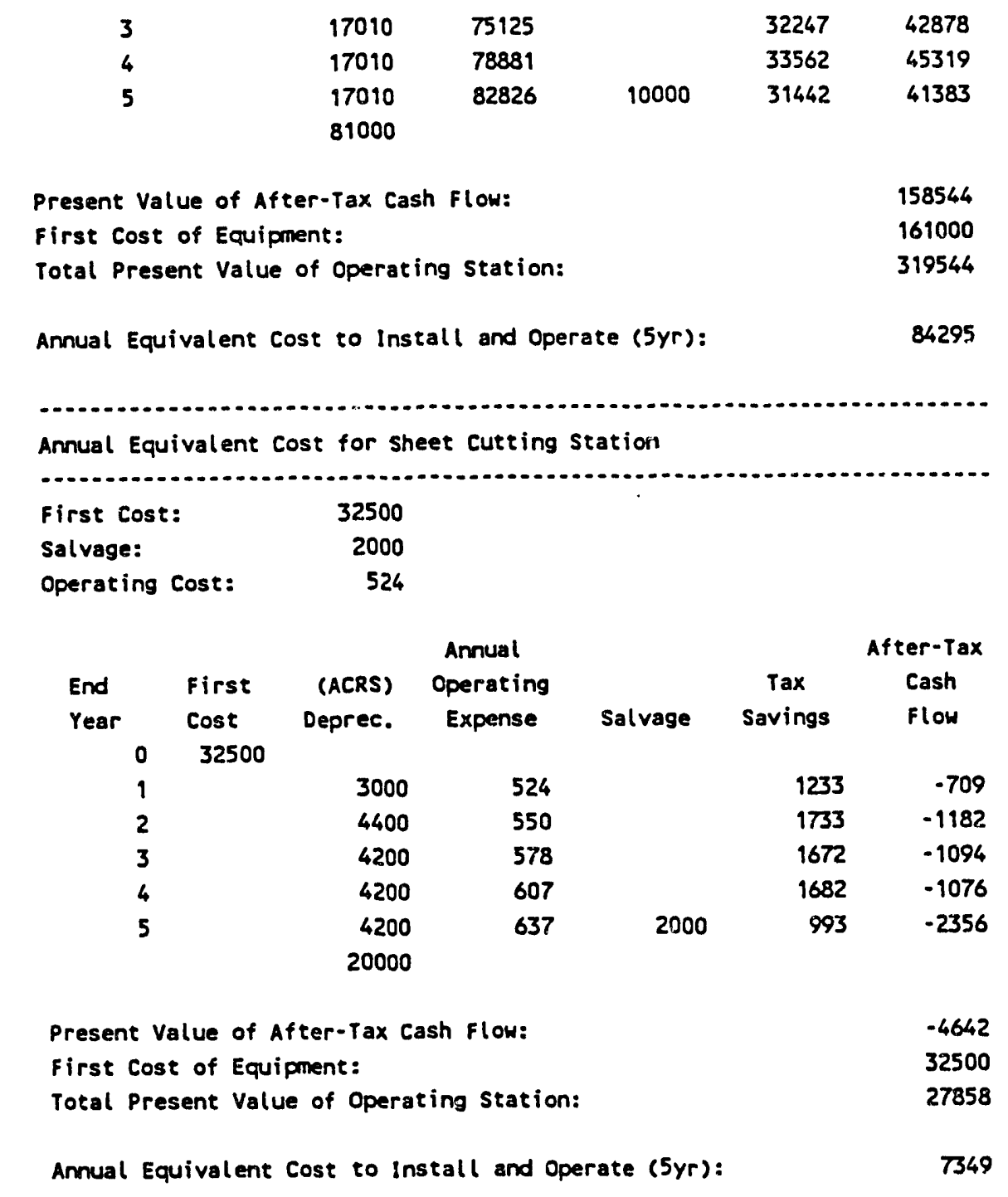

Annual Equivalent Cost for Sheet Punching Station

\begin{tabular}{|c|c|c|c|c|c|c|}
\hline \multicolumn{2}{|c|}{ First Cost: } & 67500 & & & & \\
\hline \multirow{2}{*}{$\begin{array}{l}\text { Salvage: } \\
\text { Operating }\end{array}$} & & 1500 & & & & \\
\hline & Cost: & 524 & & & & \\
\hline \multirow{8}{*}{$\begin{array}{l}\text { End } \\
\text { Year }\end{array}$} & $\begin{array}{l}\text { First } \\
\text { Cost }\end{array}$ & $\begin{array}{l}\text { (ACRS) } \\
\text { Deprec. }\end{array}$ & $\begin{array}{l}\text { Annual } \\
\text { Operating } \\
\text { Expense }\end{array}$ & Salvage & $\begin{array}{l}\text { Tax } \\
\text { Savings }\end{array}$ & $\begin{array}{l}\text { After-Tax } \\
\text { Cash } \\
\text { Flow }\end{array}$ \\
\hline & 67500 & & & & & \\
\hline & & 8250 & 524 & & 3071 & -2547 \\
\hline & & 12100 & 550 & & 4428 & -3877 \\
\hline & & 11550 & 578 & & 4245 & -3667 \\
\hline & & 11550 & 607 & & 4255 & -3648 \\
\hline & & 11550 & 637 & 1500 & 3740 & -4603 \\
\hline & & 55000 & & & & \\
\hline
\end{tabular}


First Cost of Equipment:

Total Present Value of Operating Station:

Annual Equivalent Cost to Install and Operate (5yr):

Annual Equivalent Cost for Laser Scribing Station

$\begin{array}{lr}\text { First Cost: } & 268000 \\ \text { Salvage: } & 25000\end{array}$

Operating Cost: $\quad 11794$

\begin{tabular}{|c|c|c|c|c|c|c|}
\hline \multirow{3}{*}{$\begin{array}{l}\text { End } \\
\text { Year }\end{array}$} & \multirow{3}{*}{$\begin{array}{l}\text { First } \\
\text { Cost }\end{array}$} & \multicolumn{2}{|r|}{ Annual } & \multicolumn{3}{|c|}{ After-Tax } \\
\hline & & (ACRS) & Operating & & $\operatorname{Tax}$ & Cash \\
\hline & & Deprec. & Expense & Salvage & Savings & Flor \\
\hline 0 & 268000 & & & & & \\
\hline 1 & & 22200 & 11794 & & 11898 & -104 \\
\hline 2 & & 32560 & 12383 & & 15730 & .3347 \\
\hline 3 & & 31080 & 13002 & & 15429 & -2426 \\
\hline 4 & & 31080 & 13653 & & 15656 & -2004 \\
\hline 5 & & 31080 & 14335 & 25000 & 7145 & -17810 \\
\hline & & 148000 & & & & \\
\hline
\end{tabular}

Present Value of After-Tax Cash Flow:

$-17111$

First Cost of Equipment:

268000

Total Present Value of Operating Station:

250889

Annual Equivalent Cost to Install and Operate (5yr):

66184

Annual Equivalent Cost for Screen Printing Station

First Cost:

126000

Salvage:

8000

Operating Cost:

1966

\begin{tabular}{|c|c|c|c|c|c|c|}
\hline \multirow{3}{*}{$\begin{array}{l}\text { End } \\
\text { Year }\end{array}$} & \multicolumn{4}{|c|}{ Annual } & \multicolumn{2}{|c|}{ After-Tax } \\
\hline & First & (ACRS) & Operating & & $\operatorname{Tax}$ & Cash \\
\hline & Cost & Deprec. & Expense & Salvage & Savings & Flow \\
\hline 0 & 126000 & & & & & \\
\hline 1 & & 12900 & 1966 & & 5203 & -3237 \\
\hline 2 & & 18920 & 2064 & & 7344 & -5280 \\
\hline 3 & & 18060 & 2167 & & 7079 & -4912 \\
\hline 4 & & 18060 & 2275 & & 7917 & -4842 \\
\hline 5 & & 18060 & 2389 & 8000 & 4357 & -9968 \\
\hline & & 86000 & & & & \\
\hline
\end{tabular}

Present Value of After-Tax Cash Flow:

First Cost of Equipment:

Total Present Value of Operating Station:

105506

Annual Equivalent Cost to Install and Operate (5yr):

27832 
Annual Equivalent Cost for Bus Bar Attachment Station

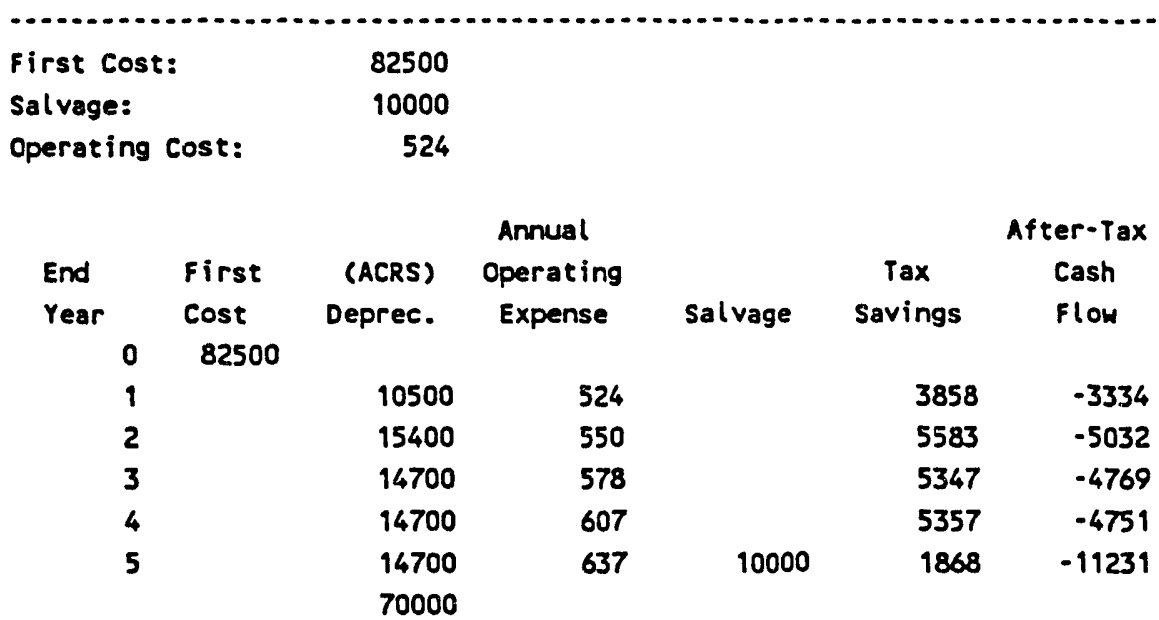

Present Value of After-Tax Cash Flow:

Annual Equivalent Cost for Encapsulation Station

\begin{tabular}{|c|c|c|c|c|c|c|}
\hline \multicolumn{2}{|c|}{ First Cost: } & 18500 & & & & \\
\hline \multicolumn{2}{|c|}{ Salvage: } & 0 & & & & \\
\hline \multirow[t]{2}{*}{ Operating } & Cost: & 84390 & & & & \\
\hline & & & Annual & & & ter-Tax \\
\hline \multirow{2}{*}{$\begin{array}{l}\text { End } \\
\text { Year }\end{array}$} & First & (ACRS) & Operating & & $\operatorname{Tax}$ & Cash \\
\hline & Cost & Deprec. & Expense & Salvage & Savings & Flow \\
\hline 0 & 18500 & & & & & \\
\hline 1 & & 900 & 84390 & & 29851 & 54538 \\
\hline 2 & & 1320 & 88609 & & 31475 & 57134 \\
\hline 3 & & 1260 & 93040 & & 33005 & 60035 \\
\hline \multicolumn{2}{|l|}{4} & 1260 & 97692 & & 34633 & 63059 \\
\hline \multirow[t]{2}{*}{5} & & 1260 & 102576 & 0 & 36343 & 66234 \\
\hline & & 6000 & & & & \\
\hline
\end{tabular}

Present Value of After-Tax Cash Floy: 


\begin{tabular}{|c|c|c|c|}
\hline $\begin{array}{l}\text { Document Control } \\
\text { Page }\end{array}$ & $\begin{array}{l}\text { 1. SERI Report No. } \\
\text { NREL/TP-214-4488 }\end{array}$ & $\begin{array}{l}\text { 2. NTIS Accossion No. } \\
\text { DE92001163 }\end{array}$ & 3. Recipient's Accession No. \\
\hline \multirow{2}{*}{\multicolumn{3}{|c|}{$\begin{array}{l}\text { 4. Title and Subtitle } \\
\text { Monolithic Amorphous Silicon Modules on Continuous Polymer Substrate }\end{array}$}} & $\begin{array}{l}\text { 5. Publication Date } \\
\text { March } 1992 \\
\end{array}$ \\
\hline & & & 6. \\
\hline \multicolumn{3}{|l|}{$\begin{array}{l}\text { 7. Author(s) } \\
\text { D.P. Grimmer }\end{array}$} & 8. Performing Organization Rept. No. \\
\hline \multirow{2}{*}{\multicolumn{3}{|c|}{$\begin{array}{l}\text { 9. Performing Organization Name and Address } \\
\text { Iowa Thin Film Technologies } \\
\text { Suite 607, ISIS } \\
\text { ISU Research Park } \\
\text { Ames, Iowa } 50010\end{array}$}} & $\begin{array}{l}\text { 10. Project/TaskWWork Unit No. } \\
\text { PV250101 }\end{array}$ \\
\hline & & & $\begin{array}{l}\text { 11. Contract (C) or Grant (G) No. } \\
\text { (C) XC-1-10057-18 } \\
\text { (G) }\end{array}$ \\
\hline \multirow{2}{*}{\multicolumn{3}{|c|}{$\begin{array}{l}\text { 12. Sponsoring Organization Name and Address } \\
\text { National Renewable Energy Laboratory } \\
1617 \text { Cole Blvd. } \\
\text { Golden, CO } 80401-3393\end{array}$}} & $\begin{array}{l}\text { 13. Type of Report \& Period Covered } \\
\text { Technical Report } \\
9 \text { January } 1991-14 \text { April } 1991 \\
\end{array}$ \\
\hline & & & 14. \\
\hline \multicolumn{4}{|c|}{$\begin{array}{l}\text { 15. Supplementary Notes } \\
\text { NREL technical monitor. R. Mitchell }\end{array}$} \\
\hline \multicolumn{4}{|c|}{$\begin{array}{l}\text { This report examines manufacturing monolithic amorphous silicon modules on a continuous polymer substrate. Module } \\
\text { production costs can be reduced by increasing module performance, expanding production, and improving and modifying } \\
\text { production processes. Material costs can be reduced by developing processes that use a 1-mil polyimide substrate and } \\
\text { multilayers of low-cost material for the front encapsulant. Research to speed up a-Si and } \mathrm{ZnO} \text { deposition rates is needed to } \\
\text { improve throughputs. To keep throughput rates compatible with depositions, multibeam fiber optic delivery systems for laser } \\
\text { scribing can be used. However, mechanical scribing systems promise even higher throughputs. Tandem cells and production } \\
\text { experience can increase device efficiency and stability. Two alternative manufacturing processes are described: (1) wet } \\
\text { etching and sheet handling and (2) wet etching and roll-to-roll fabrication. }\end{array}$} \\
\hline \multirow{2}{*}{\multicolumn{4}{|c|}{$\begin{array}{l}\text { 17. Document Analysis } \\
\text { a. Descriptors } \\
\text { amorphous silicon ; manufacturing ; modules ; continuous polymer substrate ; solar cells ; photovoltaics } \\
\text { b. Identiflers/Open-Ended Terms }\end{array}$}} \\
\hline & & & \\
\hline \multirow{2}{*}{\multicolumn{3}{|c|}{$\begin{array}{l}\text { 18. Avallabllity Statement } \\
\text { National Technical Information Service } \\
\text { U.S. Department of Commerce } \\
5285 \text { Port Royal Road } \\
\text { Springfield, VA } 22161\end{array}$}} & $\begin{array}{l}\text { 19. No. of Pages } \\
113\end{array}$ \\
\hline & & & $\begin{array}{r}\text { 20. Price } \\
\text { A06 }\end{array}$ \\
\hline
\end{tabular}

Form No. 0069E (6-30-87) 

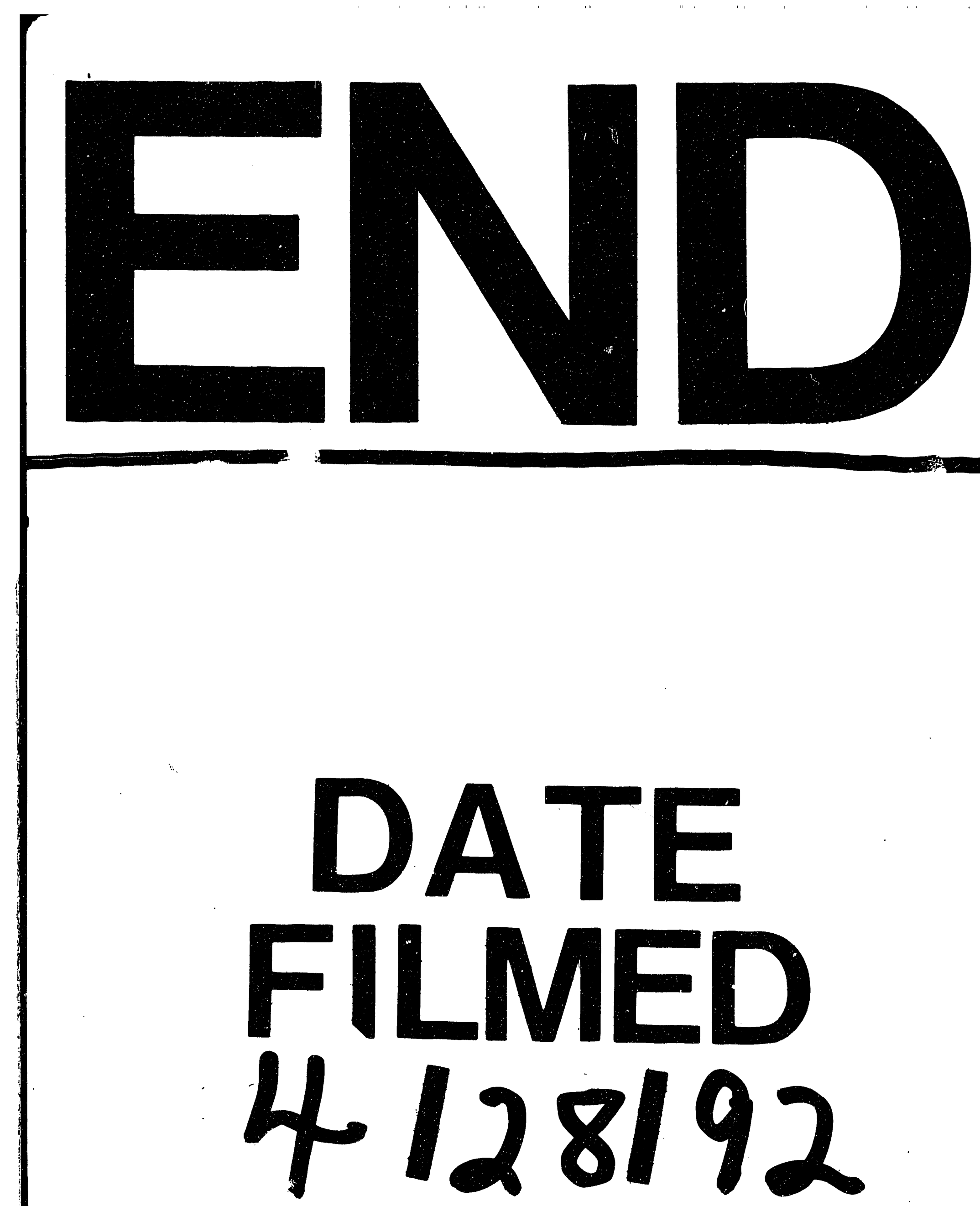
